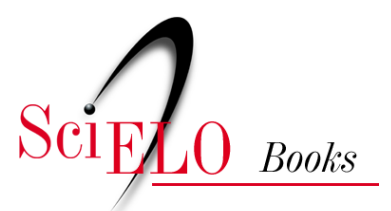

\title{
Bioética para profissionais da saúde
}

\author{
Sergio Rego \\ Marisa Palácios \\ Rodrigo Siqueira-Batista
}

REGO, S., PALÁCIOS, M., and SIQUEIRA-BATISTA, R. Bioética para profissionais da saúde [online]. Rio de Janeiro: Editora FIOCRUZ, 2009. Temas em Saúde collection, 159 p. ISBN: 978-85-7541-390-6. https://doi.org/10.7476/9788575413906.

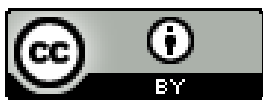

All the contents of this work, except where otherwise noted, is licensed under a Creative Commons Attribution 4.0 International license.

Todo o conteúdo deste trabalho, exceto quando houver ressalva, é publicado sob a licença Creative Commons Atribição $\underline{4.0}$. 


\section{Bió́tica para Profissionais da Saúde}




\section{FUNDAÇÃO OSWALDO CRUZ}

Presidente

Paulo Ernani Gadelha Vieira

Vice-Presidente de Ensino, Informação e Comunicação

Maria do Carmo Leal

\section{EDITORA FIOCRUZ}

\section{Diretora}

Maria do Carmo Leal

Editor Executivo

João Carlos Canossa Mendes

Editores Científicos

Nísia Trindade Lima

Ricardo Ventura Santos

Conselho Editorial

Ana Lúcia Teles Rabello

Armando de Oliveira Schubach

Carlos E. A. Coimbra Jr.

Gerson Oliveira Penna

Gilberto Hochman

Joseli Lannes Vieira

Lígia Vieira da Silva

Maria Cecília de Souza Minayo

Coleção Temas em Saúde

Editores Responsáveis

Maria do Carmo Leal

Nísia Trindade Lima

Ricardo Ventura Santos 


\section{SERGIO REGO \\ MARISA PALÁCIOS \\ RODRIGO SIQUEIRA-BATISTA}

\section{Bió́tica \\ para Profissionais da Saúde}

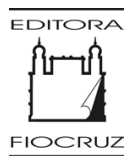


Copyright (C) 2009 dos autores

Todos os direitos desta edição reservados à

FUNDAÇÃO OSWALDO CRUZ / EDITORA

ISBN: 978-85-7541-182-7

Capa e projeto gráfico

Carlota Rios

Editoração

Robson Lima

Revisão

Irene Ernest Dias

Itamar de Oliveira

Normalização bibliográfica

Clarissa Bravo

Catalogação na fonte

Centro de Informação Científica e Tecnológica

Biblioteca da Escola Nacional de Saúde Pública Sergio Arouca

R343b Rego, Sergio

Bioética para profissionais da saúde. / Sergio Rego, Marisa Palácios e Rodrigo Siqueira-Batista. - Rio de Janeiro : Editora FIOCRUZ, 2009.

160 p. (Coleção Temas em Saúde)

1. Bioética. 2. Prática Profissional-ética. 3. Aborto. 4. Eutanásia. I. Palácios, Marisa. II. Siqueira-Batista, Rodrigo. III. Título.

$$
\text { CDD - 22.ed. - } 174.957
$$

2009

EDITORA FIOCRUZ

Av. Brasil, 4036 - Térreo - sala 112 - Manguinhos

21040-361 - Rio de Janeiro - RJ

Tels.: (21) 3882-9039 / 3882-9041

Telefax: (21) 3882-9006

e-mail: editora@fiocruz.br

http://www.fiocruz.br 
Há um fundamento ético de nossa presença no mundo. Para isso, precisamos de liberdade aliada à capacidade de assumir riscos, de decidir, de romper com as coisas... de arriscar. (...) Liberdade e independência, neste caso, andam de mãos dadas... 



\section{SUMÁRIO}

Apresentação

1. Bioética: histórico e conceitos

2. A Bioética e suas Teorias

3. Bioética e a Tomada de Decisões:

entre a clínica e a saúde pública

4. A Bioética, o Início e o Fim da Vida:

o aborto e a eutanásia

5. Comitês e Comissões Hospitalares:

de ética e de bioética

6. Epílogo

Referências

Sugestões de Leituras e Filmes 



\section{Apresentação}

Este livro destina-se aos estudantes e profissionais da área da saúde que, apesar de não especialistas em bioética, sentem-se profundamente incomodados com os problemas de sua prática cotidiana que apresentam interface com questões de natureza ética. $\mathrm{O}$ mundo mudou, a medicina mudou, a assistência médicosanitária - hoje chamada assistência à saúde, ou, de forma ainda mais apropriada, cuidado da saúde - também mudou, assim como o olhar da sociedade e a avaliação que esta elabora em resposta aos problemas morais relacionados ao processo saúde-doença. O meio social se transforma, e a forma como o homem se relaciona com ele também. Assim, para melhor compreensão da atuação laboral em saúde é premente o desenvolvimento de um novo olhar sobre os novos problemas morais, os quais têm marcante interface com as ações de prevenção, promoção e organização da saúde.

Esse novo olhar, esse novo saber e as ferramentas que são usadas para analisar essa nova realidade não devem ser considerados como algo estranho à clínica nem à saúde pública. Antes, é um saber disciplinar - por que não transdisciplinar? -, claramente aplicável tanto ao universo da prática clínica quanto ao da saúde pública.

Assim, apresentaremos análises que considerem o certo e o justo sempre de forma contextualizada, compreendendo o 
indivíduo inserido em uma dada sociedade e inscrito em um determinado ambiente, o que desde logo obriga a fugir de soluções simples, maniqueístas ou baseadas em princípios absolutos.

Tais conjecturas ganham maior relevância quando se considera o nascimento da bioética como disciplina, ainda que esta seja vista por algumas pessoas como apenas um preciosismo acadêmico, sem maior relevância prática em um país como o Brasil. Para essas não existiria a bioética, mas somente a ética. Embora possamos reconhecer nessa posição a defesa da ética em geral, na prática ela afirma uma ideia de que 'éticos' todos são - ou seja, que análise de problemas morais qualquer um pode fazer, o que torna desnecessária uma especialidade ou um saber especial. Essas premissas não estão inteiramente equivocadas, mas revelam algum grau de resistência ao pensamento acadêmico, que não é rara em certos setores da sociedade. Não há dúvida de que todas as pessoas independentemente de sua formação ou mesmo do seu grau de escolaridade - não apenas são capazes de tomar decisões sobre problemas morais que as afetam, como, de fato, as tomam. Essas decisões, por sua vez, serão resultado de análises que elas fazem, tomando como referência sua própria cultura. Mas, igualmente, não há dúvida de que a forma como essas decisões são tomadas está diretamente relacionada com fatores constitutivos dos indivíduos: sua idade, seu gênero, sua própria experiência em se confrontar e em se verem obrigados a tomar decisões sobre situações que envolvem questões morais, entre outras. Da mesma maneira, não pode ser vista como falsa a ideia de que uma pessoa com formação específica na análise de problemas morais tem um repertório maior de recursos de análise para a tomada de decisão do que aqueles que não a possuem - evidentemente, esse saber 
especializado não é absoluto (ou seja, não precisamos todos ser bioeticistas ou 'bioeticólogos'). Por outro lado, os profissionais da saúde, devido ao tipo de atividade que desenvolvem, não devem declinar de sua responsabilidade, ignorando todo um conjunto de recursos que podem ajudá-los não apenas a tomar decisões como também a auxiliar seus pacientes a tomar, eles próprios, suas decisões.

A ideia que perpassa todo o livro, orientando o olhar a cada momento, é a de que a bioética pode ser compreendida e utilizada como uma verdadeira ponte para superar as velhas - e muitas vezes falsas - dicotomias entre o individual e o coletivo - ou, em termos mais específicos, entre a clínica e a saúde pública. A bioética pode, e deve, fazer isso, na medida em que oferece uma fundamentação racional - e pretensamente imparcial - para a tomada de decisões, tornando necessário e obrigatório que as razões inerentes às questões tratadas sejam consideradas de fato. Esse olhar deve também ser situado em nosso contexto específico: um país de forte tradição autoritária, que luta para fortalecer o regime democrático e respeitar os direitos individuais e coletivos de forma mais sistemática. Nossa organização social caracteriza-se pela forte desigualdade, com o Estado tradicionalmente protegendo e agindo em defesa dos interesses de sua elite governante e a maioria da população sendo privada de seus direitos mais elementares. Esse contexto gera uma dificuldade inicial para todos que não sofremos dessa exclusão: conseguir reconhecer essa realidade no outro que nos procura para assistência ou para quem formulamos nossas ações de saúde pública.

Com efeito, procuramos, ao longo deste texto, oferecer um olhar prático sobre o tema ao qual está dedicado, ainda que, evi- 
dentemente, matizado pela fundamentação teórica - como no caso do Capítulo 2, no qual apresentamos as chamadas correntes da bioética. Fazendo jus a tal espírito e à potência da arte para desencadear reflexões atinentes aos temas aqui tratados, indicamos, ao final da publicação, uma lista de filmes, não apenas de grande qualidade técnica e beleza - alguns, genuínas obras-primas. Essas películas podem ser usadas tanto em ações educativas formais como em grupos de estudos, em cineclubes, em diretórios estudantis e outros. E apresentamos, também, uma relação de autores e algumas de suas publicações mais relevantes que não só foram referência como podem ser um caminho significativo para quem desejar se aprofundar nesses temas.

Fica, assim, o convite a todos os profissionais da saúde: que procurem exercitar sua capacidade de avaliação de problemas morais - com o desejo de que, nesse processo, estas páginas possam ser úteis -, empenhando-se no diálogo com o outro e agindo, sempre, após expor os fatos em questão (e seus valores) ao crivo de sua reflexão e análise ética. É possível que esse seja o melhor caminho para a construção de uma sociedade mais justa, equânime e fraterna. 


\section{1 |BioÉtica: Histórico e CONCEITOS}

A apresentação dos aspectos históricos e conceituais da bioética - reconhecendo-a como campo teórico, acadêmico e da práxis - é nosso objetivo neste capítulo. E por que apresentar essa perspectiva histórico-conceitual? Um relato contextualizado dessa história tornará mais fácil o entendimento da pertinência das reflexões proporcionadas pela bioética no cotidiano do cuidado com a saúde. Além disso, permitirá a compreensão de que ela não é uma opção ou uma imposição de - ou para uma corporação profissional ou da academia, mas uma decorrência da complexificação dos problemas relacionados com as novas conformações do trabalho em saúde e, por que não dizer, com a vida no complexo mundo de nossos tempos.

O legado hipocrático é reconhecido como a origem de uma sistematização de normas sobre a conduta moral de médicos, embora alguns autores vejam no chamado Código de Hamurabi os primeiros registros de regulação da prática médica. Acreditase que esse código de leis tenha sido escrito pelo rei Hamurabi, por volta do ano de 1700 a.C. No que se referia à regulação da prática médica, esse código restringia-se a regular os aspectos comerciais das relações entre médicos e pacientes; as punições e remunerações propostas referiam-se ao ganho ou à perda econômica dos envolvidos. Já os escritos habitualmente atribuídos a Hipócrates de Cós, inclusive o seu famoso juramento, detalham 
comportamentos e atitudes esperados por parte dos médicos, estabelecendo normas morais de conduta que estes deveriam observar. De fato, é em Hipócrates que se reconhece a gênese da ética médica. Há, entretanto, uma longa distância entre reconhecer esse fato histórico e considerar que nele está a origem histórica da bioética, imaginando-se assim sua história como um continuum. Não há elementos que sustentem essa posição. A ética médica, e todas as congêneres profissionais no campo da saúde, focalizam suas análises na atuação dos profissionais da saúde e baseiam-se, em geral, em valores e princípios que se pretendem absolutos. Ademais, definem o que esses profissionais devem fazer ou como devem se comportar em situações específicas, tendo como objetivos, de um lado, assegurar a boa convivência e a competição profissional honesta e respeitosa entre os pares e, de outro, garantir à sociedade que a competência legal de autorregulação - típica das profissões de consulta - será exercida sempre em defesa da sociedade, e não dos próprios interesses. Ademais, como veremos adiante, a bioética não diz respeito apenas às relações e aos fatos referentes à prática médica ou ao cuidado da saúde: seu objeto é a saúde em uma concepção bem mais ampla, e inclui não apenas a preocupação com humanos, mas com todos os seres não humanos e o ambiente no qual vivem.

Com base nessas considerações - e reconhecendo a bioética como um 'produto' da laicização (separação entre religião e Estado) e da pluralidade das sociedades democráticas do século XX -, podemos reconhecer dois eventos fundamentais como marcos do seu nascimento. O primeiro seria a reflexão do oncologista estadunidense Van Ressenlaer Potter, que em 1970 propôs o nome e a concebeu como a 'ponte' entre a ciência da natureza e 
as humanidades, enfatizando a união entre os componentes que ele considerava como os mais importantes para se atingir uma nova sabedoria, o conhecimento biológico e os valores humanos; o segundo, a fundação, pelo ginecologista e obstetra holandês radicado nos Estados Unidos André Hellegers, do Kennedy Institute of Ethics, vinculado à Georgetown University, na cidade de Washington nos Estados Unidos, no mesmo ano. Esses são dois marcos indiscutíveis para a história da bioética naquele país, mas a história não se confunde com seus marcos. Assim, para se compreender um fenômeno social é preciso conhecer aqueles que o precedem e criam as condições objetivas para que ele se manifeste. Por isso, é razoável situar o surgimento das reflexões que viriam a se conformar como bioética no âmbito das preocupações com as repercussões das pesquisas envolvendo seres humanos, nas quais a associação entre epidemiologia e clínica ocupa lugar de destaque tanto em frequência como em relevância - em última análise, seriam os indícios da construção de uma originária ponte entre a clínica e a epidemiologia/saúde pública, tese principal deste ensaio. Tais preocupações da 'préhistória' da bioética ainda eram fortemente centradas na avaliação das intenções dos agentes profissionais, mas também já prenunciavam a interface que viria a se configurar entre bioética, saúde pública e cuidado da saúde, como veremos adiante.

Não faremos, aqui, um relato histórico da evolução da reflexão ética aplicada às pesquisas científicas, o que ultrapassaria os propósitos deste livro. Sucintamente, citaremos alguns fatos relevantes que possibilitem a compreensão das mudanças ocorridas neste campo. 


\section{As tensões nAS PESQUisas CiENTÍFicas}

O desenvolvimento das ciências biomédicas apoiou-se fortemente na realização de experiências científicas, em conformidade com o conceito de ciência que predomina(va) nesse campo do conhecimento. Nem sempre se realizou uma clara distinção entre 'cobaias humanas' e cobaias 'não humanas', em termos de valorização moral, nas pesquisas realizadas em clínicas ou hospitais, desde que esses humanos não fossem de uma categoria social relevante na sociedade. Assim, por exemplo, Pasteur propôs a dom Pedro II que autorizasse o uso de prisioneiros brasileiros condenados à pena de morte como cobaias na testagem da vacina antirrábica. No mesmo século, nos Estados Unidos, um cirurgião militar, William Beaumont, observou e estudou, durante três anos, o processo de digestão em um paciente através de uma ferida a bala aberta em seu tubo digestivo. Neste último caso, um contrato garantia ao paciente uma remuneração mensal para que ficasse permanentemente disponível para o investigador.

O século XIX não conheceu normas que disciplinassem a realização de pesquisas com seres humanos. O padrão era utilizar os próprios pacientes como sujeitos das pesquisas, buscando um tratamento melhor para eles, ou recorrer à autoadministração do medicamento, no caso de o próprio médico ou dentista receber a droga em teste. Muito do que foi feito em termos de pesquisa naquela época teve como justificativa o "progresso da ciência".

Na Prússia, entretanto, já em 1900 foi criada a primeira regulamentação que disciplinava a realização de pesquisas não terapêuticas em humanos, tornando o consentimento dos participantes um requisito obrigatório para sua realização. Na Alemanha, em 1930, foi realizado um teste com a vacina BCG, dirigida 
à prevenção da tuberculose, em cem crianças, sem a obtenção do consentimento de seus responsáveis para a participação na pesquisa; 75 dessas crianças morreram no decorrer do projeto. O fato ficou conhecido como "o desastre de Lübeck". O episódio levou o ministro do Interior da Alemanha a estabelecer, em 1931, as Diretrizes para Novas Terapêuticas e Pesquisa em Seres Humanos, as quais não foram suficientes para impedir as pesquisas abusivas com judeus, ciganos e prisioneiros em geral, durante a Segunda Guerra Mundial.

Em 1932, nos Estados Unidos da América (EUA), iniciou-se na cidade de Tuskegee a famosa pesquisa sobre a história natural da sífilis com 399 negros com sífilis, que não apenas não foram tratados quando a penicilina passou a estar disponível para a terapêutica desta enfermidade como também tiveram impedido o acesso a tal intervenção. Apenas em 1972, após denúncia do episódio pela imprensa leiga, o estudo foi suspenso. Note-se a respeito desse estudo que ele foi permanentemente acompanhado e avaliado pelas autoridades sanitárias nos National Institutes of Medicine e que, além disso, diversos artigos foram publicados ao longo dos quarenta anos de pesquisa. Apenas em maio de 1997 o presidente Clinton pediu desculpas, em nome do governo, aos sobreviventes. Durante esses quarenta anos a comunidade científica estadunidense e do mundo (afinal, os artigos foram publicados em periódicos de referência mundial) acompanhou a pesquisa e seus resultados em 13 artigos que foram revistos por pares e publicados! O que isso significa? Que esses pesquisadores eram pessoas de má índole? Pessoas cruéis e insensíveis? Provavelmente, não. Elas expressavam, sim, a compreensão da comunidade científica de que determinadas ações e estudos se 
justificavam pela contribuição que dariam para o avanço do conhecimento científico, independentemente do desrespeito aos tratados e convenções, de natureza moral, então vigentes.

Embora as pesquisas realizadas durante a Segunda Guerra Mundial pelos principais países envolvidos no conflito (incluindo EUA e Inglaterra) tenham tido grande repercussão global - especialmente no âmbito da discussão sobre o que se poderia e o que não se poderia fazer com seres humanos -, o fato é que não foram suficientes para efetivamente mudar a forma como cientistas em geral viam a questão. Muitas pesquisas ainda foram feitas - e continuam sendo realizadas, em menor escala, até hoje - sem que os riscos sejam considerados tão seriamente quanto a possibilidade de benefício. Os interesses favorecidos, em nome da ciência, quase sempre foram de natureza econômica. Sim, admitamos que a ciência avançou, mas cabe perguntar: que riscos são aceitáveis para aqueles que participam de pesquisas científicas? A resposta a essa pergunta tem mudado bastante desde o início do século XX. Reconhecemos, contudo, que tal mudança não parte especialmente das populações envolvidas nos estudos, ainda que estas aceitem cada vez menos ser usadas de forma indiscriminada como cobaias em pesquisas das quais podem não obter maiores benefícios.

Essa pressão social por mudança pode ser reconhecida, por exemplo, na já referida denúncia da pesquisa de Tuskegee com os negros estadunidenses, como também na reportagem que foi publicada pelo jornal Correio Braz̧iliense em março de 2002, na qual o jornalista Solano Nascimento apresenta alguns exemplos de pesquisas abusivas realizadas no Brasil, por pesquisadores brasileiros. A maioria dos estudos denunciados já se encontrava 
publicada na época, tanto em periódicos científicos nacionais quanto internacionais. Esses estudos incluíram, por exemplo, pesquisas com pacientes com hipertensão arterial sistêmica leve a moderada que tiveram suas medicações suspensas e substituídas por placebo; provocação de crise de asma em crianças, inclusive lactentes, sendo que parte delas recebeu placebo e não um medicamento efetivo; pesquisa com mais de 350 crianças baianas portadoras de esquistossomose mansônica na qual a metade delas não foi tratada de fato, mas recebeu apenas placebos; pacientes com síndrome do pânico que tiveram crises induzidas pelo pesquisador com o único propósito de observar a crise ao vivo, e outros que foram tratados com placebo havendo medicamento eficaz conhecido.

Mas não foi apenas no campo das pesquisas científicas que utilizavam humanos que ocorreram mudanças em relação à definição, por parte da sociedade, do que pode ou não ser tolerado. Mesmo a realização de pesquisas envolvendo animais não humanos foi (e é cada vez mais) questionada, de forma, por vezes, bastante violenta. Questiona-se não apenas o sofrimento ao qual esses animais são submetidos, mas também a impossibilidade de que estes se beneficiem dos procedimentos dos quais tomam parte. No Brasil, desde 2008 existe um instrumento legal - a Lei Arouca - que disciplina o uso de animais em pesquisas. $\mathrm{O}$ fato de o Congresso Nacional ter se sensibilizado quanto à necessidade de regulamentar tal prática atesta a relevância do tema. Questões semelhantes têm sido levantadas no concernente às investigações que envolvem outros seres vivos - por exemplo, plantas. Essas e outras questões serão abordadas com mais detalhes em um segundo volume sobre bioética, a ser lançado no próximo ano. 


\section{As tENSÕES NA PRÁtica CLÍNICA}

As práticas na clínica também não se deram sem novos conflitos durante o século XX. Em primeiro lugar porque o modelo de um profissional como alguém capaz de resolver, sozinho, todos os problemas de saúde de seus pacientes, utilizando-se dos recursos que carregava em sua maleta médica, foi rapidamente suplantado ainda na primeira metade do século. A divisão do trabalho médico - fruto da especialização e da complexidade das relações sociais - e a transformação do hospital em local privilegiado para o acesso aos recursos terapêuticos deixaram a figura do médico 'portador da maleta' restrita ao imaginário saudosista - ou desinformado - da corporação.

As novas tecnologias aplicadas na assistência à saúde trouxeram inusitadas situações que demanda(ra) $\mathrm{m}$, aos profissionais e à população, uma reflexão sobre seus limites e possibilidades. Para os médicos, salvar a vida sempre foi a única resposta adequada sobre o que fazer com um indivíduo enfermo que o procura. Se estiver doente, deve salvá-lo. Mas a assistência à saúde se complexificou - sendo, inclusive, rediscutida e recomposta em termos de cuidado da saúde -, e passou a demandar respostas morais adequadas à nova realidade.

Vejamos, pois, um exemplo clássico do novo tipo de problema moral com o qual os médicos passaram a se defrontar no início da segunda metade do século passado, também aqui relatado inicialmente pela imprensa. Trata-se dos acontecimentos em Seattle descritos por Shana Alexander em um artigo publicado na revista Life, em 1962, relacionados ao programa de diálise renal do Swedish Hospital. Na ocasião, foi criado o 
Life or Death Committee, composto por sete membros da comunidade de Seattle, Washington, que tinham de decidir quais pacientes, entre os elegíveis, seriam recebidos pelo programa, pois não havia recursos para atender a todos eles. Em uma situação como essa, dizer que todos devem ser salvos é irrelevante e sem consequências, pois não se trata de uma questão de desejo ou de opção. Com efeito, nesse caso, como o princípio absoluto que considera a vida como o bem maior mostrou-se insuficiente para resolver a questão, outros valores/critérios precisaram ser utilizados para que fosse tomada uma decisão e resolvido o problema: qual dos sujeitos teria prioridade no acesso à terapia substitutiva renal? E assim foi feito.

Esse tipo de situação continua frequente nos dias de hoje. Por exemplo, quando é necessário decidir quem terá acesso aos poucos órgãos disponíveis para transplantes que poderão salvar várias vidas ou, ainda, qual dos inúmeros doentes que lotam as emergências e estão em estado grave deverá ser internado na Unidade de Terapia Intensiva (UTI). O fato de já existir uma decisão pactuada - a fila única - não significa que o problema esteja de fato resolvido. A fila significa que se utilizará a antiguidade na demanda como critério de definição. A princípio parece justo, posto que os que necessitam há mais tempo de um órgão têm prioridade sobre os demais. Mas de fato não é assim que ocorre, e não apenas em nosso país. A rigor, o acesso aos serviços de saúde e a um diagnóstico preciso sobre a necessidade de um transplante não é igual para todos os membros da sociedade. Não é novidade, em nenhum país, que pessoas com pior situação socioeconômica têm acesso aos serviços de saúde pior do que aquelas que não dependem, por exemplo, do sistema público. Generalizando essa 
condição, pode-se dizer que todos os membros de grupos que têm restrito acesso aos serviços de saúde têm também menos chance de receber o diagnóstico que indique a necessidade de um transplante e, por conseguinte, de entrar na fila. Qual seria a solução mais justa para o problema? A fila? A gravidade de cada caso, definida por algum critério racional? Não vamos nos estender no tema, aqui introduzido apenas para que fique mais claro como os problemas (e suas possíveis soluções) são complexos. Desse episódio aqui narrado, destaca-se, usualmente, apenas sua relação direta com os problemas clínicos; entretanto, uma análise mais detida expõe também uma interface com questões típicas da saúde pública, como a formulação de políticas e a gestão de serviços.

A década de 60 do século passado foi particularmente significativa para o entendimento das mudanças ocorridas na prática da assistência à saúde com a incorporação de novas tecnologias. Nessa época, ocorreram mudanças nos mais diferentes campos do pensamento, e é razoável que nela se reconheça um ambiente bastante predisposto a mudanças culturais. Nas artes, nas ciências e mesmo nas religiões, valores foram questionados e redimensionados. Mesmo na Igreja católica, uma das estruturas sociais mais conservadoras da sociedade ocidental: convocado em 1959, iniciado em 1962 e encerrado em 1965, o Concílio Vaticano II provocou significativas mudanças, que ainda hoje são questionadas pelos setores mais conservadores dessa igreja.

No vasto campo do conhecimento e de práticas que é o cuidado da saúde, individual e coletiva, os focos de questionamentos foram os mais diversos, como, por exemplo, o movimento em defesa do direito à educação e demais direitos sociais (presentes 
em inúmeros países, inclusive no Brasil); os movimentos pelos direitos civis dos negros, especialmente nos Estados Unidos, e o movimento hippie, internacional, que se afirmava, em última análise, como de defesa dos direitos individuais.

Também merecem destaque o lançamento comercial da "pílula" anticoncepcional, a partir do qual as mulheres conseguem segurança para dissociarem a relação sexual da reprodução, com grande impacto no que veio a ser chamado de "liberação sexual" e no movimento de defesa dos direitos das mulheres; o movimento em defesa da legalização do aborto nos Estados Unidos e em outros países de economias mais desenvolvidas, enfatizando os direitos dos indivíduos do sexo feminino, e a realização do primeiro transplante cardíaco, pelo médico Christiaan Barnard, na África do Sul, em dezembro de 1967. Este último abalou a moral vigente: o coração é considerado, pelo senso comum, como a sede dos sentimentos e da memória, e transplantá-lo era visto quase como equivalente a criar uma quimera, ou seja, um monstro composto por partes de diferentes tipos de animais! Ademais, diretamente associado a esse evento houve a redefinição do próprio conceito de morte, posto que para se transplantar o coração era preciso que ele estivesse em atividade. Assim, a definição de morte como o momento no qual os batimentos cardíacos cessavam foi abandonada. Uma comissão de especialistas da Harvard Medical School criou um novo conceito, a morte encefálica, a qual se dá antes da parada cardíaca propriamente dita. É notável: o próprio conceito de morte foi modificado!

É possível entender essa mudança apenas como uma rápida adaptação às necessidades do desenvolvimento biotecnológico; mas é necessário considerar que esse mesmo desenvolvimento 
encontra-se alicerçado na melhor compreensão dos processos vitais fundamentais e no desenvolvimento dos métodos passíveis de serem usados no diagnóstico de tais funções. Será que não se está vivendo uma situação semelhante neste momento, com as atuais discussões sobre o que fazer com os fetos anencéfalos ou sobre a utilização de células-tronco embrionárias? O que passa a ser discutido é não apenas o conceito de vida, do ponto de vista biológico, mas a própria ideia de 'pessoa'. O que é uma pessoa? Que vida é relevante do ponto de vista moral?

Alguns podem considerar, preconceituosamente, que perguntas desse tipo são como algumas feitas por filósofos, as quais, aparentemente, "não levam a nada" ou são "coisa para quem não tem o que fazer", como se ouve eventualmente em sala de aula. Mas, fugir de perguntas como essas significa dar a outros o direito de respondê-las (muitas vezes em lugar daquele que desiste de pensar...). Qualquer ser vivo tem os mesmos direitos? Se o ser vivo é um ser humano, isso lhe dá direitos adicionais em relação a outros seres vivos? Que animais, como os homens, têm consciência de si? Que seres vivos devem ser protegidos? Apenas os humanos? Todos aqueles que são capazes de sentir dor, de sofrer? Todos os seres vivos, ou não?

Depois dessa breve digressão, retomemos o relato histórico, para identificar os momentos ou fatos relevantes para a conformação da bioética. Nesse âmbito, podemos comentar um fato ocorrido em New Jersey, Estados Unidos, em 1975: o coma de Karen Ann Quinlan. Karen, então uma jovem de 21 anos, foi admitida, em coma, no setor de emergência de um hospital, após uma sequência de eventos na qual se incluem uma dieta alimentar radical e o consumo de bebidas alcoólicas associadas com diaze- 
pínicos. Acredita-se que Karen, inconsciente, tenha vomitado e aspirado o seu próprio vômito, o que teria provocado um episódio de parada respiratória. Estima-se que ela tenha ficado em apneia por 15 a 20 minutos até ser reanimada. Levada ao hospital, permaneceu por nove dias não responsiva, até que foi transferida para outro hospital. Lá, após meses de internação com suas condições progressivamente se deteriorando - chegou a pesar menos de 36 kg -, em alimentação por sonda nasogástrica e em respiração assistida com respirador, seus pais tomaram uma decisão drástica: solicitaram aos médicos que a atendiam que retirassem o seu apoio ventilatório. É importante que procuremos entender a posição dos pais, que eram católicos: ambos acreditavam que não havia esperança de recuperação para a filha - o diagnóstico de Karen era de estado vegetativo persistente - e entendiam que a manutenção da respiração assistida não era natural, e que se devia permitir que a evolução do quadro se desse sem maiores interferências. Os profissionais que a atendiam se recusaram a interromper a ventilação, alegando que esse procedimento equivaleria a matar Karen. Os pais recorreram à Justiça, pedindo autorização para fazê-lo. Aqui, mais uma inflexão importante: a Justiça demandou que o comitê de ética do hospital opinasse sobre o caso. Mas no hospital não existia um comitê desse tipo, e foi necessário criá-lo. O Poder Judiciário decidiu a favor da solicitação dos pais, e o apoio respiratório foi retirado. Karen viveu por mais nove anos.

A determinação legal de New Jersey levou em consideração o fato de os pais serem pessoas religiosas, vinculadas à Igreja católi$\mathrm{ca}$, a qual se manifestou nos autos do processo citando o discurso do papa Pio XII dirigido aos anestesistas, em 24 de novembro de 1957: "que o tratamento que estava sendo oferecido constituía 
meios extraordinários de preservação da vida e, portanto, não há nenhuma obrigação de usá-lo nem de dar a permissão aos médicos para usarem" (Supreme Court of New Jersey, 1976). Embora esse argumento conste nos autos do processo na Suprema Corte, a decisão não se baseou nele, posto que foi reconhecido que o direito de seguir ditames de uma dada religião pode - e deve - ser regulado pelo Estado.

Os eventos aqui narrados, envolvendo Karen Ann Quinlan e seus pais, geraram consequências importantes para a sociedade estadunidense - e mesmo para o mundo -, por terem provocado a reflexão aplicada a um caso concreto sobre: a importância que os comitês de ética hospitalar (composto por profissionais com formações diferentes e indivíduos sem formação na área da saúde) têm ou podem ter no encaminhamento de problemas como esse (ver Capítulo 4); o papel que pais e familiares podem e devem ter na tomada de decisões no melhor interesse de seus filhos ou parentes; a importância de se criar a possibilidade de que cada indivíduo se manifeste, em vida, a respeito de como gostaria de ser tratado no caso de estar inconsciente - as chamadas diretrizes antecipadas. Este último ponto ainda não é muito debatido no Brasil, de modo que há um estranhamento muito grande quando alguém se manifesta dessa forma, e frequentemente os profissionais da saúde costumam achar que sua obrigação de salvar vidas ainda é ilimitada, embora os limites existam e sejam amplamente reconhecidos pelas diversas instâncias que se pronunciam sobre o tema - inclusive, como vimos, a própria Igreja católica.

Poderíamos narrar muitas outras histórias, e narraremos algumas delas adiante, neste livro, de modo a recompor a matriz social na qual foi gestada a bioética, entendida como mudança 
de atitude - individual e coletiva - diante das novas demandas apresentadas no século XX. Tal movimento - quiçá assemelhado ao próprio nascimento da filosofia, 25 séculos antes, na Grécia acabou ganhando força em diferentes regiões, incluindo o Brasil, como comentaremos a seguir.

\section{SURGIMENTO DA BIOÉTICA NO BRASIL}

A emergência formal da bioética no Brasil só ocorreu após a promulgação da Constituição Federal, em 1988. E não por acaso, pois em um ambiente no qual as liberdades individuais e coletivas - e os direitos individuais e sociais - não eram plenamente reconhecidos e respeitados, reconhecia-se um terreno inóspito e infértil para a difusão de um saber cuja reflexão e prática estão ancoradas no debate e na tomada de decisões racionais. Da mesma maneira, tanto os campos da assistência médico-sanitária como os espaços de formação de pessoal para essa prática também estavam permeados por uma cultura autoritária e excludente. Com a redemocratização do país, esses dois ambientes sociais vêm, paulatinamente, abrindo-se à reflexão crítica, à diversidade de argumentos e ao respeito pela diferença. Um dos maiores desafios é exatamente o de propor e fomentar uma reflexão crítica que esteja fundamentada na própria cultura e responda às questões suscitadas pela nossa realidade.

Nessa tentativa de delinear brevemente a história da bioética no Brasil, buscaremos assinalar os marcos mais óbvios, deixando para o futuro um esforço mais sistematizado de identificar situações menos divulgadas - mas que poderiam ter relevância significativa. Assim, por exemplo, não comentaremos fatos mais remotos - como a recusa de Pedro II ao pleito de Pasteur no 
século XIX - e outros relacionados com a própria história da conformação do Sistema Único de Saúde (SUS) e da organização das profissões, para enfatizar aqueles diretamente vinculados à bioética.

Assim, o primeiro marco parece ser a aprovação, pelo Conselho Nacional de Saúde (CNS), da Resolução 01 de 1988, a primeira tentativa de criar uma regulamentação ética para a realização de estudos envolvendo seres humanos como sujeitos. Apesar da importância da iniciativa, esse texto legal não teve um impacto significativo no mundo científico, possivelmente pela forma pouco participativa com que foi preparado, por não haver no país massa crítica que permitisse fazê-lo valer.

Cronologicamente, o segundo marco é a publicação do primeiro número da revista Bioética, pelo Conselho Federal de Medicina (CFM), em 1993. Sua relevância é inquestionável, até mesmo pelo fato de contar com não médicos em seu conselho editorial. A revista se organiza sob a forma de simpósios temáticos, abordando temas e problemas de relevância para a área de saúde. Simbolicamente, seu primeiro número foi dedicado ao tema 'Aids e bioética', que mobiliza uma parcela significativa da população e um contingente expressivo de ativistas sociais que lutam pela melhoria da qualidade da atenção aos doentes e infectados pelo HIV.

O terceiro marco é a criação da Sociedade Brasileira de Bioética (SBB), em 18 de fevereiro de 1995. Com a sua criação, a bioética passou a contar com uma organização comprometida com sua divulgação. O primeiro congresso da sociedade ocorreu em agosto de 1996, em São Paulo, quando se estabeleceu a periodicidade bienal para sua realização. Desde então, as reuniões 
tornaram-se regulares, e mais e mais eventos temáticos foram acontecendo, não necessariamente no âmbito da SBB, mas com a participação de seus afiliados. Nesse contexto, um acontecimento paradigmático foi a realização, em Brasilia, do Sexto Congresso Mundial de Bioética da International Association of Bioethics (IAB), em 2003.

Em 1996, após cerca de um ano de debates em todo o país, o CNS aprovou a sua Resolução 196/96, que regulamentou a realização de pesquisas envolvendo seres humanos como sujeitos no Brasil. Essa resolução é um dos instrumentos que mais têm contribuído para difundir as reflexões sobre bioética no meio acadêmico. Se, por um lado, essa difusão é extremamente positiva - assim como seu impacto nas pesquisas -, por outro ocorre o que parece ser uma simplificação extrema da própria bioética, muitas vezes compreendida ou confundida com o próprio principialismo. O principialismo é uma das principais correntes da bioética; como veremos no Capítulo 2, baseia-se em quatro princípios que são igualmente válidos: o respeito à autonomia do paciente, a beneficência (fazer o bem), a não maleficência (não fazer o mal) e a justiça.

Como os processos educativos são fundamentais na difusão de um saber, não podemos deixar de mencionar, ainda que brevemente, a decisão de incluir a bioética nas diretrizes norteadoras para a organização dos cursos de graduação na área da saúde como um dos conteúdos e uma das competências desejáveis para os graduados. O problema é que quando essas diretrizes foram criadas não existiam cursos de pós-graduação, em nível de mestrado e doutorado, dirigidos a esse campo, mas apenas especializações no Rio de Janeiro, em Brasília, em São Paulo 
e em Porto Alegre, entre outros. Essa lacuna começou a ser preenchida com o estabelecimento de uma cátedra de bioética da Organização das Nações Unidas para a Educação, a Ciência e a Cultura (Unesco), na Universidade de Brasília, em 2004; do mestrado no Centro Universitário São Camilo, em 2005; e da primeira turma do Programa de Mestrado e Doutorado em Bioética e Saúde Pública da Universidade de Brasília (UnB), em 2009. Espera-se que em 2010 já tenham iniciado as atividades de mais um programa, o Programa de Bioética, Ética Aplicada e Saúde Coletiva, que foi submetido à apreciação da Coordenação de Aperfeiçoamento de Pessoal de Nível Superior (Capes) este ano e deverá ser oferecido em associação entre a Universidade Federal do Rio de Janeiro (UFRJ), a Fundação Oswaldo Cruz (Fiocruz), a Universidade do Estado do Rio de Janeiro (Uerj) e a Universidade Federal Fluminense (UFF).

Não há muito relatos de casos clínicos que ajudem a conformar decisões que possam ser caracterizadas como paradigmáticas no Brasil, apesar de a revista Bioética oferecer, em suas páginas, casos que podem auxiliar uma abordagem 'casuística' (ver Capítulo 2). Um caso, entretanto, merece destaque, por ter envolvido uma decisão judicial tomada por demanda dos maiores interessados. Para prevenir a obstinação terapêutica, os pais de uma criança lactente, acometida por grave enfermidade, solicitaram autorização para que ela não fosse reanimada nem fossem instituídas medidas extraordinárias de manutenção da sua vida, o que a Justiça autorizou. A criança faleceu uma semana após a decisão judicial (Diniz, 2006).

Várias questões têm conquistado mais espaço na imprensa em geral, estimulando, entre a sociedade brasileira, um amplo 
debate sobre os aspectos éticos dessas práticas. O primeiro tema, quase sempre mal debatido - por ser tratado de forma preconceituosa -, é o aborto. Como o governo brasileiro tem admitido o debate, paulatinamente a imprensa tem aberto espaço; uma novidade é a garantia, com alguma frequência, de oportunidade para defensores do direito ao abortamento se manifestarem e debaterem seus pontos de vista. O segundo tema, diretamente vinculado ao primeiro, é o abortamento dos fetos anencéfalos. Tal questão chegou ao Supremo Tribunal Federal, de modo claramente amadurecido; acredita-se que essa prática seja formalmente autorizada por essa corte. Seguramente, poderá influenciar essa decisão a Resolução 1.752 aprovada pelo CFM em 2004. Outra determinação do CFM que deverá exercer um impacto profundo na prática clínica e na jurisprudência sobre o tema é a que regulamentou a prática da chamada ortotanásia, isto é, a morte sem sofrimento (Resolução 1.805/2006), como veremos no Capítulo 4.

Outros temas que estão na ordem do dia e já alcançaram os tribunais superiores são a utilização de células-tronco embrionárias para pesquisas (quando, implicitamente, os conceitos de vida e de pessoa estiveram em ampla discussão em todos os meios de comunicação) e a judicialização das decisões político-sanitárias em relação ao fornecimento de remédios que não constam da lista de medicamentos oferecidos pelo SUS. Discute-se, neste último caso, a própria concepção de justiça sanitária.

\section{MAS, AFInAL, 0 QUE É A BIOÉTICA?}

O fato de a bioética não ter se conformado apenas como uma ética biomédica, mas integrado e relacionado saberes e campos 
do conhecimento diversos, a tornam mais próxima da concepção holística proposta por Potter do que do preconizado pelos teóricos da Georgetown University. Destaque-se, todavia, que nas análises aplicadas à clínica e à pesquisa o modelo principialista desenvolvido nessa universidade mantém-se ainda claramente hegemônico. Embora ainda haja os que percebem a bioética como mera extensão da ética médica, ela pode ser definida como o estudo sistemático das dimensões morais das ciências da vida e dos cuidados em saúde, que emprega uma variedade de metodologias éticas em um ambiente interdisciplinar. Outra forma de defini-la é dizer que a bioética se preocupa em analisar os argumentos morais a favor e contra determinadas práticas humanas que afetam a qualidade de vida e o bem-estar dos humanos e dos outros seres vivos e a qualidade dos seus ambientes, e em tomar decisões baseadas nas análises anteriores. Assim, a bioética, como ética aplicada que é, tem duas dimensões indissociáveis, uma descritiva e uma normativa.

Tem sido defendido, especialmente pelos bioeticistas F. Roland Schramm, da Fiocruz, e Miguel Kottow, da Universidad de Chile, que a 'proteção' seja o princípio norteador das análises e decisões a serem tomadas. Tal concepção encontra respaldo no conteúdo da Declaração Universal sobre Bioética e Direitos Humanos da Unesco, de 2005. Essa declaração, embora antropocêntrica, inclui entre suas preocupações os problemas morais relacionados com o meio ambiente e com animais não humanos.

Um editorial do American Journal of Public Health analisou as relações entre a bioética e a saúde pública no contexto acadêmico norte-americano e ressaltou 
a tensão produzida pela orientação predominante em favor das liberdades civis que são encontradas na bioética, como opostas às orientações utilitaristas, paternalísticas e comunitárias que têm marcado o campo da saúde pública ao longo de sua história. (Levin \& Fleischman, 2002: 166)

Essa tensão pode ser entendida tanto como consequência da insuficiência do referencial principialista, quando aplicado ao campo da saúde pública, quanto como expressão da importância relativa que o princípio da autonomia conquistou na bioética estadunidense ou mesmo como expressão do conflito entre interesses do indivíduo e da sociedade. Como afirmou Rego (2007), a bioética pode contribuir de forma significativa com a saúde pública no desafio de considerar igualmente interesses individuais e coletivos, o bem individual e o coletivo. Assim, o desafio seria não o de impor restrições às liberdades individuais, mas o de focar a formulação das políticas públicas nos interesses da coletividade, fundamentando-as criteriosamente do ponto de vista ético.

O entendimento da abrangência da bioética - especialmente em seus diálogos com a clínica e a saúde pública - depende, igualmente, do reconhecimento das relações que este campo estabelece com outros dos saberes, especialmente a ética, a moral, a religião, o direito, a ciência e a técnica.

\section{BioÉticA E SUAS RELAÇÕES COM OUTROS SABERES}

Estabelecer as interseções e distinções da bioética em relação a outros domínios do saber-fazer não é mera demonstração de erudição, mas algo necessário ao reconhecimento de uma genuína questão bioética. De fato, uma das questões que se apresentam na atuação do profissional da saúde em seu dia a dia é a dificul- 
dade, muitas vezes presente, de identificar um problema bioético no bojo de uma situação clínica ou de saúde pública, tendo em vista seus aspectos éticos, morais, religiosos, jurídicos, científicos e técnicos.

Nesses termos, devemos considerar, sucintamente, os seguintes conceitos:

- Ética - A palavra 'ética' pode ser compreendida em dois sentidos, usual (senso comum) e técnico; com efeito, nos termos do 'senso comum' a ética diz respeito ao conjunto de regras vigentes que os membros de um grupo (por exemplo, a sociedade) adotam para evitar e/ou resolver seus conflitos internos, desde que enunciados em termos de bem-mal, correto-incorreto e justo-injusto; em termos 'técnicos', designa uma disciplina própria da filosofia, que se dedica a investigar o conjunto de reflexões críticas sobre as regras morais vigentes, com base nas quais se buscam as razões (argumentos) que fundamentem, justifiquem ou legitimem os comportamentos.

As relações entre 'ética' e 'bioética' são motivo de grande debate na literatura especializada, no qual se apresentam desde concepções que reconhecem na bioética apenas uma 'continuação' da tradição ética filosófica - ou, ainda, a mera aplicação prática, concreta, da teoria ética - até aquelas que entendem a bioética como saber completamente autônomo, mas capaz de utilizar algumas 'ferramentas' desenvolvidas pelo discurso ético. Nos capítulos 2 e 3, comentaremos as relações entre esses saberes, no âmbito da apreciação de um problema bioético e da 'tomada de decisão'.

- Moral - A moral é conceituada, mais comumente, como o conjunto de costumes de uma sociedade, podendo ser considerada, pois, como o 'objeto' da ética: “o termo 'ética’ é reser- 
vado para a disciplina filosófica que estuda racionalmente a conduta humana, sob o ponto de vista dos deveres e das virtudes morais" (Hortal, 1994: 25). Alguns autores consideram moral e ética como sinônimos, perspectiva que adotamos preferencialmente neste livro.

- Religião - O termo 'religião' é polissêmico, podendo abranger a "crença na divindade ou em Deus, o ato de orar ou de participar num ritual ou ato de culto, meditar sobre algo divino ou a atitude emocional do indivíduo com respeito a algo que transcende este mundo (ou se percebe dessa maneira)" (Ferrer \& Álvarez, 2005: 55). Assim, é possível pensar sobre as interseções entre bioética e religião, desde aquelas que reconhecem nesta o 'fundamento' da primeira - éticas e bioéticas cristãs, budistas e outras - até aquelas que reconhecem que a bioética pode, e deve, ser considerada e 'exercida' em uma perspectiva não religiosa, mas puramente racional e razoável, tal como proposto no corpo teórico das bioéticas laicas (por exemplo, ao se considerar a possibilidade de uma compaixão laica). Todavia, um dos mais relevantes princípios da bioética é a 'sacralidade da vida', de tessitura marcadamente religiosa.

Do ponto de vista da atuação profissional na saúde, em muitas ocasiões será preciso equacionar aspectos bioéticos e religiosos de uma dada questão. Por exemplo, um enfermo que se recusa a receber sangue - pertencente à religião Testemunha de Jeová ou outra -, mas necessita de tal procedimento para manter sua vida deverá ter sua situação avaliada levando-se em consideração a sua 'religião', o respeito à sua 'autonomia' para decidir e, também, a 'beneficência' dos membros da equipe que podem reconhecer que, nesse caso, o 'bem' impõe que seja realizada a transfusão sanguínea (entre outros princípios éticos e religiosos que possam ser evocados). O que propomos neste livro é que a perspectiva religiosa deve ser considerada 
sempre que a decisão a ser tomada estiver limitada à perspectiva de um indivíduo ou de sua família, por exemplo. Mas que para as discussões sobre políticas de saúde o que deve se impor é sempre a perspectiva laica, que possibilita o respeito individual às crenças ou não crenças das pessoas eventualmente envolvidas em uma questão específica.

- Direito - O termo diz respeito ao conjunto de saberes e práticas, organizados em termos de leis e normas, que tem por objetivo a regulamentação da vida em sociedade (Abbagnano, 2003). As relações entre bioética e direito são bastante íntimas, ainda que estes campos não sejam, evidentemente, redutíveis um ao outro. Não é correto entender que o debate ético e bioético esteja subordinado ou seja inseparável do debate jurídico, pois, se assim fosse, não haveria como discutir do ponto de vista ético a ordem estabelecida ou passar a considerar como ético o fato de algo estar contido em alguma norma legal. Nesse último caso, o Estado nazista seria considerado ético, posto que muitas das atrocidades cometidas no III Reich foram praticadas "em nome da lei”. Por outro lado, o direito não pode impor todas as exigências da ética, sob pena de tornar as regras impraticáveis para a maioria dos cidadãos.

$\mathrm{Na}$ esfera de relações entre bioética e direito, vale ressaltar a emergência do biodireito, ramo do direito que abrange a teoria, a legislação e a jurisprudência relativas à ação humana, tendo em vista os avanços da biologia, da biotecnologia e da medicina.

- Ciência - Trata-se de um gênero de conhecimento capaz de garantir a própria validade, opondo-se, assim, à 'opinião', a qual não pode ter sua validade afiançada. Uma distinção importante, relacionada ao 'objeto do conhecimento', pode ser feita entre as ciências naturais, ou da natureza - por exemplo, 
astronomia, física, química e outras - e as ciências da cultura, ou do homem - p. ex., antropologia, educação e outras.

As relações entre ética e ciência são bastante antigas, remontando à Antiguidade grega. Coube a Aristóteles a distinção entre os juízos da ordem do 'ser' - saber 'necessário' -, típicos da ciência, e os da ordem do 'dever ser' - saber contingente -, afins à ética. Por exemplo, na superfície da Terra o movimento esperado para uma maçã largada do alto de um edifício 'será, necessariamente', a queda (conhecimento científico), ao passo que a gestação de um anencéfalo 'poderá ser', de modo 'contingente', interrompida. Nos séculos XX e XXI, têm sido questionados, com rigor cada vez maior, os aspectos éticos das práticas científicas.

- 'Técnica - originariamente, tem o sentido de 'arte', 'ofício' ou 'saber-fazer', "procedimento qualquer, regido por normas e provido de certa eficácia” (Abbagnano, 2003: 939), ou seja, como 'meio para atingir determinados fins'; essa acepção é questionada pelo filósofo Martin Heidegger (2001: 27), para quem a técnica é o “destino do homem”. Diferentes problemas da prática do profissional da saúde são considerados como questões puramente técnicas, e os trabalhadores envolvidos não identificam os aspectos bioéticos que tais problemas encerram. Assim, por exemplo, a indicação de se realizar ou não, em um enfermo com doença grave, uma entubação orotraqueal - que não envolve possibilidades curativas e provoca um extremo sofrimento - é tratada, muitas vezes, como uma questão apenas técnica, desconsiderando-se todas as nuances bioéticas implicadas em uma decisão dessa natureza.

Mais recentemente, têm sido propostos os termos 'tecnociência' - que designa a ciência contemporânea - e 'biotecnociência' - definida por Schramm (2005a) como o conjunto interdisciplinar 
e integrado de saberes teóricos, habilidades tecnocientíficas e aplicações industriais referentes aos sistemas e processos vivos chamados 'biotecnologias'. Tais termos têm ampliado as possibilidades do debate conceitual que a ciência, a técnica e a ética envolvem.

Com estes breves apontamentos, nossa intenção foi apreciar algumas factíveis 'interlocuções' da bioética - ainda que haja diversas outras interlocuções possíveis, como, por exemplo, com a administração, a antropologia, a educação. Mas nosso objetivo principal é a delimitação dos campos de aproximação e de afastamento desses interlocutores, a qual pode ser útil no enfrentamento de um desafio: 'a delimitação de um genuíno problema bioético' nas situações da vida cotidiana.

Procuramos, neste capítulo, apresentar os principais aspectos históricos e conceituais da bioética, tendo como foco a apresentação do saber-fazer deste campo do conhecimento. Trata-se de uma primeira aproximação, que deve ser entendida, sobretudo, como um convite aos meandros da apaixonante - e intrigante - abrangência dos debates bioéticos. No próximo capítulo apresentaremos os fundamentos teóricos habitualmente utilizados no debate bioético. Para tal, o ponto de partida será um caso elaborado por um dos autores, Sergio Rego, para discussão em sala de aula. 


\section{I A BioÉtica e suas TeORIAS}

A bioética tem se desenvolvido de modo extremamente veloz desde a sua origem, na segunda metade do século XX reconhecendo-se a publicação do trabalho de Potter como o marco de seu 'nascimento' -, com substantivo desenvolvimento de correntes e modelos.

Para abordagem dessa temática - mote do presente capítulo -, consideremos o seguinte caso: "A decisão do dr. Arnaldo: quem sobe?".

$\mathrm{O}$ dr. Arnaldo é médico residente de cirurgia geral em um hospital situado em um grande centro urbano. Durante seu plantão na emergência, no início de uma madrugada, dois pacientes baleados foram admitidos no hospital. O que foi trazido pelo Sistema de Atendimento de Urgência Municipal, Denílson, é um policial militar de 48 anos, ferido quando tentava impedir um assalto a um casal de namorados. O outro, José, 19 anos, trazido no carro de patrulhamento ostensivo da polícia, é o homem suspeito de ter alvejado o policial e que havia sido baleado por este. Ambos apresentam quadro clínico instável, precisando ser submetidos a um procedimento cirúrgico de urgência, mas o estado de José é mais grave. O residente determina à equipe de enfermagem que encaminhe os dois ao centro cirúrgico, mas é informado de que só há uma mesa cirúrgica disponível pelas próximas quatro horas. Só um poderá ser operado com todos os 
recursos do e no centro cirúrgico; o outro deverá ser operado na própria emergência ou aguardar a liberação de uma sala cirúrgica. A decisão tem que ser tomada imediatamente. O médico pensa por alguns instantes e decide encaminhar o policial ao centro cirúrgico.

$\mathrm{O}$ dr. Arnaldo tomou a decisão certa ou errada? É possível concordar ou discordar da decisão tomada por ele? Por quê?

A análise de um caso exemplo é o que propomos neste capítulo, tendo em vista sua aplicação na apreciação de algumas das teorias mais utilizadas em bioética. Esperamos tornar claro, em termos práticos, o modo como se utilizam os referenciais teóricos de bioética na prática em saúde. Todavia, é preciso, antes, fazer um alerta óbvio, mas não dispensável: as presentes descrições das correntes sofrem as limitações relativas ao espaço e ao objetivo do livro. Por isso, recomendamos fortemente que sejam consideradas as sugestões de leitura apresentadas ao final deste volume para o aprofundamento dos conhecimentos sobre as correntes. Vejamos, pois, como as questões morais interferem na tomada de decisão no caso concreto.

Qual seria a solução técnica para esse caso? E qual é o verdadeiro limite para o uso apenas do chamado 'saber técnico', ou 'profissional', no caso? Por mais que possamos questionar, por meio da técnica, as possibilidades de se estimar com segurança as chances de vida ou de morte de qualquer paciente, é factível para o médico avaliar as suas condições clínicas e informar, de acordo com o conhecimento clínico-epidemiológico, as probabilidades tanto da sobrevida em si quanto de sua qualidade. Essas probabilidades, mesmo que teóricas - ou seja, a aplicação ao caso implica a assunção de muitos graus de incerteza -, são 
ainda indicadores, dados concretos, e é razoável utilizá-las mantendo-se claro o limite de sua aplicação aos casos concretos. $\mathrm{Na}$ situação concreta, é possível que o profissional da saúde tenha clareza, mediante a avaliação clínica, sobre qual dos quadros é mais grave. A decisão de intervir sobre o caso mais grave já não é uma decisão técnica isenta de questões morais (ver as relações da bioética com os outros saberes no Capítulo 1). Por que operar aquele cujo estado é mais grave?

Será que a opção foi operar o paciente em estado menos grave porque ele teria mais chances de sobreviver do que aquele em situação mais grave? Será que a escolha se justifica porque o bandido é o que menos contribui para o bem-estar da sociedade? O policial, afinal, presta um serviço relevante à coletividade. Então... Será possível buscar, nas diferentes correntes da bioética, argumentos que sustentem ou critiquem a decisão do dr. Arnaldo?

\section{Principialismo}

O principialismo foi a primeira corrente bioética a se estruturar. As condições históricas que estão na base da sua constituição tiveram como um dos marcos o Relatório Belmont, publicado em 1978 como resultado do trabalho desenvolvido pela National Commission for the Protection of Human Subjects of Biomedical and Behavioral Research, criada pelo governo dos Estados Unidos em 1974. Essa comissão foi constituída após a denúncia da pesquisa com homens negros sifilíticos, em Tuskegee - a qual coroou uma série de escândalos em pesquisas com seres humanos -, e teve como incumbência definir que princípios deveriam orientar a realização de tais estudos. Como resultado de seu trabalho, a comissão propôs a observância de três princípios básicos, gerais, 
que orientariam as regras para proteção dos humanos em situação de pesquisa: o respeito pelas pessoas, a beneficência e a justiça. Ao contrário do que muitos imaginam, o trabalho realizado por Beauchamp e Childress (2002) não foi elaborado depois da conclusão do Relatório Belmont. Segundo Beauchamp, sua incorporação ao grupo de Belmont só se deu depois que a redação do livro estava bem adiantada, o que não impediu que um trabalho influenciasse o outro. Tal livro, Principles of Biomedical Ethics [Princípios da Ética Biomédica, versão em português já disponível], sistematiza, para o campo da prática biomédica, os princípios prima facie - princípios não absolutos que são igualmente válidos, em um primeiro momento, devendo pois ser cotejados, criteriosamente, para solução do problema - que foram apresentados para a prática da pesquisa científica. Nele, o respeito às pessoas foi definido como o respeito à autonomia das pessoas, o dever de agir com justiça, e a obrigação de fazer o bem foi desdobrada, sendo expressa a obrigação de não causar dano.

\section{Características do principialismo}

O que caracteriza as abordagens principialistas (ou seja, baseadas em princípios) é o reconhecimento de um mínimo de normas morais centrais, com base nas quais se procede ao julgamento da eticidade de uma ação. O foco central da abordagem são os princípios morais que orientam a ação. Normas morais (princípios e regras) são diretrizes gerais para a ação que especificam que determinadas ações são proibidas, requeridas ou permitidas em determinadas circunstâncias. A diferença entre princípios e regras está em que princípios são as diretrizes mais gerais e as regras são mais específicas. 
$\mathrm{Na}$ abordagem principialista - de acordo com o proposto por Beauchamp e Childress (2002), base para este texto - compreende-se que a ação eticamente adequada é aquela que se orienta por princípios morais universalmente aceitos. São considerados princípios fundamentais a beneficência, a não maleficência, o respeito à autonomia e a justiça. Não representam uma novidade em si, visto que é possível reconhecê-los nos ideais da Revolução Francesa - liberdade, igualdade e fraternidade - e mesmo no pensamento helênico antigo - ou seja, as obrigações de 'primeiro não causar dano' e de 'fazer o bem’ da tradição médica hipocrática, ou ainda mais remotamente. Desses princípios centrais podem ser derivadas regras específicas, tais como: dizer a verdade; cumprir suas promessas; proteger a privacidade do paciente; não passar adiante informações que foram dadas em confiança; obter consentimento sempre - no cuidado e na pesquisa -, entre outros. Esses são exemplos de regras cuja validade dificilmente alguém poderia negar. São regras morais já consagradas na prática em saúde. Mas como aproximar tais princípios e regras aos casos concretos? Como tomar decisão se os princípios forem conflitantes?

Existem três maneiras distintas de operar tal aproximação, segundo Childress (1998): aplicação, balanceamento e especificação. $\mathrm{Na}$ aplicação, o julgamento da ação concreta é derivado/ deduzido diretamente do princípio moral. Childress salienta que a maior parte das abordagens baseadas em princípios rejeita a aplicação direta por considerá-la uma forma mecânica que não ajuda a tomada de decisão quando há conflito entre princípios. No balanceamento está implícita a noção de força ou peso: qual princípio tem prioridade no momento e na situação concreta? A forma de responder a essa pergunta admite três concepções 
diferentes. Em termos ilustrativos, os princípios seriam meras recomendações, não teriam a força da obrigação moral. Para uma segunda concepção, os princípios seriam tomados como obrigações morais prima facie. Outra possibilidade seria tomá-los como regras absolutas. Observa-se, então, que há um gradiente de intensidade entre considerar princípios como meras recomendações e tomá-los como regras absolutas. Na especificação há intenção de tornar a regra válida nas mais abrangentes situações. São exemplos de especificação: não mentir para quem tem direito à verdade; não matar inocentes. Se não matar é inaplicável - por exemplo, quando esta é a única maneira de proteger a própria vida -, quando se especifica 'inocentes' aumentam as chances de que essa proposição seja universalmente aplicável.

Para o principialismo, o método mais adequado para aproximar os quatro princípios e as regras derivadas das situações concretas é o balanceamento, que permite tomá-los como obrigações morais prima facie, entre a regra absoluta e a mera recomendação. É preciso ter argumentos muito bons para infringir um princípio quando há conflito, pois deve-se justificar na situação concreta por que tal princípio foi rejeitado ou sobreposto a outro. É importante ressaltar que no principialismo não há, a priori, uma hierarquia entre os princípios. Assim, em determinada situação, quando as regras e princípios são contraditórios, são atribuídas prioridades válidas apenas para aquela situação concreta.

\section{Os principios}

Embora 'autonomia' seja um termo sujeito a várias interpretações, no âmbito do principialismo ela deve ser compreendida como o governo pessoal do eu, que é livre tanto de interferências 
controladoras por parte de outros quanto de limitações pessoais que criam embaraços para a escolha, tais como a compreensão inadequada. $\mathrm{O}$ indivíduo autônomo age livremente de acordo com um plano escolhido por ele mesmo, da mesma forma como um governo independente administra seu território e define suas políticas. Para essa corrente, respeitar um agente autônomo é, no mínimo, reconhecer o direito dessa pessoa de ter suas opiniões, fazer suas escolhas e agir com base em valores e crenças pessoais. Esse respeito envolve a ação respeitosa, e não meramente uma atitude respeitosa. Ele exige também mais que obrigações de não intervenção nas decisões das pessoas, pois inclui o compromisso tácito de sustentar as capacidades dos outros de escolher autonomamente, diminuindo os temores e outras condições que arruínem sua autonomia.

$\mathrm{O}$ princípio do respeito à autonomia individual tem sua legitimidade ainda frequentemente questionada na atual prática laboral em saúde, o que dificulta sua aceitação. De fato, é bastante comum ouvir de médicos - e de outros profissionais da saúde - que "o paciente não entende o que é melhor pra ele", ou que "o paciente não estudou seis anos e mais a residência para saber medicina”. Portanto, quem sabe é quem estudou. É claro que são os profissionais que detêm o saber técnico, mas é igualmente evidente - ou ao menos deveria ser - que esse saber não é capaz de estabelecer o que o paciente considera melhor para si. Aquelas palavras podem ser simplesmente um reflexo do desrespeito à autonomia do paciente - o profissional acha que sabe o que é melhor para o enfermo -, ou uma preocupação sincera do profissional em esclarecer ao máximo o paciente, "trocando em miúdos" e explicando em uma linguagem simples o que le- 
vou anos para compreender. O paciente pode não ser capaz de formular hipóteses diagnósticas sobre o seu sofrimento ou o de outra pessoa, mas pode, sem dúvida, compreender o que se passa consigo caso haja uma explicação razoável, em uma linguagem compreensível para uma pessoa do seu nível cultural.

Respeito à autonomia no cuidado da saúde ou na pesquisa significa apresentar, de forma clara e transparente, o que se passa com o sujeito e as opções que a ciência biomédica coloca a seu dispor, respeitando a sua decisão sobre o que ele entende ser melhor para si. Pressupõe, igualmente, compreender que aquilo que o saber fazer biomédico coloca à disposição - como melhor alternativa, do ponto de vista profissional - pode não ser o mais adequado aos desejos do enfermo, ao que ele tem como perspectiva de futuro, ao que ele acha razoável viver ou não viver. Respeitar a autonomia do paciente significa compreender que o sujeito pode ter perspectivas e desejos diferentes dos seus. O respeito à autonomia como obrigação moral do profissional da saúde não é algo óbvio. Ao contrário, o médico em maior grau e todo profissional da saúde, em menor grau, são treinados para agir sempre em defesa da vida e do que se pensa comumente ser o melhor interesse do paciente, como se isso fosse um dado imutável, previamente conhecido. É como se houvesse um homem/mulher médio(a) que reagisse sempre da mesma maneira e, em caso de qualquer desvio em relação a essa maneira, o médico ou profissional da saúde estivesse autorizado a lhe atribuir um 'diagnóstico' ou, pior, um juízo de valor: "Não entendeu”, "Há uma doença mental” (depressão é a mais comumente mencionada) ou "É um fundamentalista religioso". Situação similar ocorre quando o sujeito expressa o 
desejo de não ser reanimado ou de não se submeter a uma cirurgia mutiladora, e o profissional é capaz de lhe dizer que não está havendo entendimento sobre a gravidade do caso ou que o sujeito está deprimido, o que faz com que sua compreensão sobre a realidade esteja "esfumaçada". Nessas circunstâncias, o que o profissional, muitas vezes, não consegue admitir é que o paciente tem outros valores a priorizar.

O princípio da não maleficência afirma a obrigação de não infligir dano a alguém intencionalmente. É um princípio que costuma gerar dificuldades para alguns profissionais da saúde, especialmente no que diz respeito à distinção com o princípio da beneficência. Atribuído a Hipócrates, o Primum non nocere (Primeiro não causar dano) é uma máxima da ética médica tradicional. O juramento do médico de Cós, repetido a cada turma que se forma em medicina, afirma que o médico aplicará os tratamentos para o bem do doente segundo seu próprio poder e entendimento, e nunca o usará para causar dano ou mal a alguém. E que entrará nas casas para o bem do doente, abstendo-se de todo dano voluntário.

Prejuízo ou dano pode ser compreendido como a ação de contrariar, frustrar ou interpor obstáculos aos interesses de alguém. O que significa dizer que há uma obrigação moral em não contrariar, frustrar ou interpor obstáculos aos interesses de alguém.

Esse princípio está bastante relacionado com os debates sobre o fim da vida que apresentaremos no Capítulo 4, em que discutimos se causar a morte a alguém é, do ponto de vista moral, mais ou menos relevante do que deixar morrer, ou se a aplicação da regra do duplo efeito - quando a morte é acelerada como consequência de ações médicas que visam não ao êxito 
letal, mas sim ao alívio do sofrimento de um paciente, como no caso do emprego de uma dose de benzodiazepínico para minimizar a ansiedade e a angústia, gerando, secundariamente, depressão respiratória e óbito - pode justificar a decisão de levar alguém à morte. Evitar causar danos a outrem constitui uma obrigação moral prima facie; sempre se pode perguntar o que significa dano para o paciente moral, ou seja, aquele que sofre a ação.

O princípio da beneficência difere da não maleficência na medida em que a beneficência implica ações positivas e a não maleficência evita ações prejudiciais; entretanto, é perceptível um continum entre não maleficência e beneficência que torna impossível precisar o limite entre os dois conceitos. No principialismo distinguem-se dois princípios de beneficência: 'beneficência positiva' e 'utilidade'. O primeiro implica a obrigação de fazer o bem, e pode se expressar nas regras de beneficência que podem ser intuitivamente admitidas, como proteger e defender os direitos dos outros; atuar para que outros não sofram danos; eliminar as condições que causarão danos a outrem; ajudar pessoas inaptas e socorrer pessoas que estão em perigo.

Tais regras poderiam ser caracterizadas como derivadas do princípio da beneficência geral. Quando se pondera sobre o princípio da beneficência específica, entende-se a obrigação de agir de modo beneficente para determinados grupos de pessoas: obrigações para com familiares, pacientes e outros. O princípio da utilidade refere-se ao balanço de riscos e benefícios ou custos e efetividade.

No cuidado da saúde ou na pesquisa, na clínica ou na saúde pública, o princípio da beneficência tem se direcionado à 
realização de um balanço entre riscos e benefícios potenciais. A questão fundamental a responder é: quais são os possíveis benefícios e riscos para os afetados pela ação proposta? Para uma análise sobre a melhor ação para determinada circunstância é preciso identificar as ações possíveis e, para cada uma, quem serão os afetados e quais serão os possíveis benefícios e riscos delas decorrentes. Assim, pode-se fazer o balanço de benefícios e riscos e determinar aquela ação que melhor atende ao princípio da beneficência. Entretanto, convém lembrar que a análise principialista envolve os quatro princípios prima facie, o que significa que não basta que haja um balanço positivo entre riscos e benefícios, mas é necessário também que se evitem os danos, que se respeite a autonomia e que a decisão tomada seja justa, o que remete ao quarto princípio - a justiça.

Quando se pensa na aplicação do princípio da justiça às situações relacionadas ao cuidado da saúde e à pesquisa, a referência é a justiça distributiva: qual ação equaciona melhor a distribuição dos riscos e dos benefícios? Sendo necessário decidir que ação é a mais justa, como proceder? Nesses termos, podem-se distribuir os benefícios e os riscos de maneiras diversas - por exemplo, a cada um uma parte igual; a cada um a parte que atenda a suas necessidades; a cada um a parcela que merece contribuição/esforço/ papel social; e a cada um de acordo com o sorteio.

Assim, é possível pensar em uma série de critérios para a distribuição dos benefícios e dos riscos ou danos.

Após essas breves ponderações sobre o principialismo, podemos formular alguns argumentos que nos ajudarão a pensar no caso aqui proposto, o do dr. Arnaldo. 


\section{0 principialismo e o caso do dr. Arnaldo}

Um primeiro princípio, o do respeito à autonomia, levaria a conversar sobre as possibilidades de tratamento com os dois e, quando isso não fosse possível, com suas famílias. Essa conversa inclui não apenas o diagnóstico preciso sobre o estado de saúde deles, mas também as alternativas de tratamento naquele hospital. Embora se pense que o razoável é imaginar que ambos desejam ser atendidos logo e imediatamente, pode ser que, com essa conversa, fique claro que o policial gostaria de ser cuidado no hospital da polícia, por já ter sido tratado nessa unidade, com sucesso, de um ferimento anterior, ou por ter receio de ser internado em qualquer hospital que não o de sua corporação, ou por qualquer outra razão. Outra possibilidade - por que não? - é que se receba a informação de que o policial é seguidor de alguma religião que imponha algum tipo de restrição no atendimento como no caso das Testemunhas de Jeová, que não aceitam, por exemplo, receber transfusões -, o que levaria à necessidade de se repensar a conduta. Ou seja, ouvir o paciente poderá trazer informações cruciais sobre como é a vida que ele acha que merece ser vivida por ele.

No caso analisado há um balanço positivo de riscos e benefícios com a intervenção médica. A cirurgia, para os dois baleados, implicará a possibilidade de viver, ao passo que se não houver intervenção muito provavelmente a morte ocorrerá em pouco tempo. O balanço de riscos e benefícios que propõe o principialismo não deixa dúvida de que a intervenção cirúrgica é a ação que mais benefícios poderá trazer; embora a cirurgia envolva riscos, não realizá-la implica risco de morte. É preciso examinar mais as alternativas e seus riscos e benefícios, como a transferência de 
um deles, para que se possa determinar qual dos dois teria mais chances de sobrevida com a transferência. Outra possibilidade é a realização de procedimentos fora da sala de cirurgia. Nesse caso, também riscos e benefícios têm de ser balanceados e comparados com as alternativas. Algumas vezes - e parece ser o caso do dr. Arnaldo -, a única alternativa adequada ao princípio da beneficência é a realização imediata da cirurgia em ambos os baleados. Mas, como se sabe, apenas uma sala cirúrgica está disponível.

O princípio da não maleficência está diretamente vinculado à obrigação moral de minimização dos danos. Para uma adequada avaliação dos possíveis malefícios, é necessário examinar em detalhes todas as alternativas de tratamento e seus riscos para cada um dos baleados. Pode ser que se chegue à conclusão de que um deles suportaria melhor uma alternativa paliativa no próprio ambiente do serviço de emergência. Escolhendo-se um deles para operar, o outro ficará sem o melhor tratamento (a cirurgia em ambiente cirúrgico), e isso é um malefício. Nesse caso, é fundamental observar a obrigação de tentar minimizar os danos, o que poderá implicar a escolha de alternativa que menos danos ou mais benefícios promoverá.

A aplicação do princípio da justiça ao caso implica a justa distribuição dos ônus e bônus, ou seja, o modo como serão distribuídos os recursos disponíveis para o tratamento dos baleados. Pode-se propor, como argumento em favor da hipótese de levar o policial ao centro cirúrgico, a importância dele para sua família; como é um homem de mais de 40 anos, deve ter, inclusive, filhos. Outro argumento poderá se vincular ao valor social, uma vez que o policial estava exercendo a função que a sociedade lhe atribuiu de protegê-la, de alto valor social. Veja que nesses argumentos 
não se julga o outro como bandido; quem vai dizer se o rapaz é ou não autor de um crime, se há circunstâncias que o agravem ou atenuem, é o sistema judicial. Mas se o sistema judicial já o tivesse julgado culpado, caberia ao sistema de saúde oferecer a pena? Mas, de volta ao argumento do mérito, o rapaz tem apenas 19 anos, supostamente não tem qualificação - ainda que tenha estudado - , houve menos investimento social em sua formação.

Por outro lado, poderíamos argumentar que, como o rapaz é mais jovem, ele teria maior probabilidade de se recuperar completamente, ou quase. Assim, seu balanço de riscos e benefícios seria mais favorável do que o do policial.

Outra forma de decidir qual é a distribuição mais justa seria um sorteio. Esse método pode ser visto como a pior das soluções, pois implica o reconhecimento de que não foi possível chegar a uma conclusão de outra forma, o que parece pouco provável e ainda menos aceitável.

\section{MOdELO UTILITARISTA}

Nos termos da abordagem utilitarista, o que faz uma ação ser correta ou errada são as suas consequências. A consequência mais importante é o aumento ou diminuição da quantidade de bem-estar de todos os afetados pela ação. Nesse sentido, a melhor ação é a que produz o máximo de bem-estar. O modelo utilitarista baseia-se em três conceitos constituintes principais: consequencialismo; máximo de bem-estar; agregacionismo. Esta breve sistematização se baseará no pensamento de Richard Mervyn Hare (1998).

Enquanto na abordagem principialista propõe-se considerar os princípios que orientam a ação para uma análise ética que auxilie 
a tomada de decisão, o modelo utilitarista propõe pensar nas consequências das possíveis ações para que se possa fazer escolhas mais bem justificadas. Essas proposições, centradas nas ações e em suas consequências, demandam um conceito apropriado de ação, que corresponderia a fazer alguma diferença no curso dos acontecimentos. É muito importante que isso seja compreendido: se uma pessoa não empreendeu nenhuma mudança nos acontecimentos, então não houve ação - isto faz com que se admita como ação, também, a omissão, quando esta de fato interfere nos acontecimentos. Um exemplo usado por Hare para ilustrar a primazia das consequências do ponto de vista moral refere-se ao ato de matar alguém. Ao concordar que matar alguém é errado, todos concordarão também que puxar o gatilho (que é a ação) leva alguém à morte (matar é consequência de puxar o gatilho). Nesse caso, o que confere o estatuto de certo ou errado, de bem ou mal à ação é a sua consequência.

O máximo de bem-estar é outro conceito importante para o utilitarismo, visto que a consequência mais importante é o aumento ou diminuição da quantidade de bem-estar de todos os afetados pela ação. Como bem-estar é caracterizado como a obtenção de alto grau ou grau razoável de qualidade de vida que no todo a pessoa almeja ou prefere ter, a preferência é um elemento fundamental. Referimo-nos à preferência do afetado pela ação, e não à preferência daquele que age. É preciso também considerar a temporalidade da ação quando se trata do que Hare chama de preferências: 'agora-para-agora'; 'depois-para-depois', 'agora-para-depois'. Inclui-se, aqui, o problema do sujeito que em determinado momento afirma preferir não ser mantido vivo se estiver seriamente incapaz, e quando o tempo chega deseja muito viver, não importa como, caso em que conflita a preferência 
'agora-para-depois' com a 'depois-para-depois'. Parece simples que nesse caso a preferência 'agora-para-depois' tenha menor força. Por outro lado, fica a pergunta: quando se deve considerar a preferência 'agora-para-depois'?

O agregacionismo, último componente do modelo utilitarista, apoia-se no pressuposto de que o que vale é a 'soma' dos 'bens'. Quando há escolha entre que ações devem ser realizadas, a melhor será aquela que proverá maximamente os interesses de forma agregada (soma de todos os interesses). Isso implica não considerar a distribuição, mas sim a soma. Se uma consequência é mais bem-estar distribuído para poucos afetados e outra consequência é menos bem-estar no total, mas distribuído por um número maior de pessoas, a opção baseada no modelo utilitarista será pela ação que tem a primeira consequência. Para os utilitaristas, todos os interesses devem ser igualmente considerados, inclusive os de todos os seres sencientes, ou seja, capazes de sentir dor. Em resumo, a abordagem utilitarista propõe agir de forma a garantir o maior bem-estar para o maior número de envolvidos.

$\mathrm{Na}$ abordagem utilitarista, o caso do dr. Arnaldo seria analisado de maneira a se realizar um cálculo do maior benefício. Os dois baleados necessitam de intervenção cirúrgica para a manutenção de suas vidas. Só há uma sala cirúrgica disponível. Os quadros clínicos dos dois estão demandando cuidados. Partindo do pressuposto de que o resultado que ambos os baleados preferem ter é viver, ou seja, curar-se (ou ao menos sobreviver sem sequelas), os benefícios terão de ser somados para se verificar qual dentre as possibilidades de ação é a que representa a melhor equação de maior soma. É, sem dúvida, difícil realizar qualquer cálculo neste caso. Mas pode-se vincular a uma abordagem utilitarista o 
argumento de que o rapaz de 19 anos tem mais vida para viver do que o policial de 48. Outro cálculo pode ser o de que se o estado de José é mais grave, é ele quem deve morrer primeiro se nada for feito. Nessa perspectiva, uma alternativa pertinente poderia ser operar primeiro o paciente em estado mais grave porque assim haveria alguma chance de operar os dois. Caso se invertesse a ordem, certamente a probabilidade de que o paciente cujo quadro é mais grave venha a morrer aumentaria muito. Uma objeção a esse argumento, comumente utilizada, é a de que os pacientes em estado mais grave apresentam mais chances de morrer mesmo que sofram as intervenções demandadas. Assim, o menos grave teria mais chances de sobreviver, e caso contrário - ou seja, na opção por operar primeiro o que está em estado mais grave - as chances de os dois morrerem seriam maiores.

Por outro lado, quando se pensa em todos os afetados pela ação, constata-se que o policial tem esposa e filhos, os quais se beneficiarão com a manutenção de sua vida, pois dele dependem emocional e financeiramente, o que lhe conferiria prioridade, ao menos se não houver informação sobre o outro paciente.

Há uma grande dificuldade em implantar a proposta utilitarista, que é exatamente a necessidade de que esse cálculo agregado e comparativo de bem-estar seja feito de modo imparcial e isento (se é que isso é realmente possível...).

\section{ÉTICA DO CUIDAR}

A ética do cuidar é uma forma de compreensão do agir ético e está baseada em cinco ideias centrais: atenção moral; compreensão com simpatia; consciência das relações; acomodação e resposta. Trata-se de uma forma de consequencialismo que questiona os 
valores da imparcialidade, impessoalidade e equidade. A voz do cuidado compreende que os agentes estão envolvidos em contextos sociais particulares, relações e narrativas pessoais, que dirigem suas atenções morais a outros reais e estão abertos a compreender esses outros com simpatia e a com eles se identificar.

Lawrence Kohlberg foi um dos mais destacados pensadores que formularam a teoria do desenvolvimento moral cognitivo. Carol Gilligan, inicialmente uma de suas alunas, reconheceu na teoria de Kohlberg um viés sexista e propôs um novo olhar teórico para a compreensão do desenvolvimento moral baseado na ideia do cuidado. Gilligan publicou os resultados de sua pesquisa inicial no livro In a Different Voice, no qual buscava ressaltar que era possível entender a moralidade de outra forma, com outro olhar, o olhar do cuidado. Na perspectiva do 'cuidar', o problema moral surge quando há responsabilidades conflitantes, e para a voz da justiça quando há conflitos de direitos. E assim, a moralidade dos direitos difere da moralidade da responsabilidade em sua ênfase na separação e não na conexão, na sua consideração do individual e não do relacionamento, como elemento primário. Manning (1998) assinala que a voz da justiça compreende o indivíduo como um ser isolado, como alguém abstrato que segue regras abstratas de maneira fria e imparcial. Já a voz do cuidado compreenderia os agentes morais inseridos em seus contextos sociais específicos, com suas relações e narrativas pessoais, que dirigem suas atenções morais a outros seres reais, reconhecidos em seus contextos de vida.

Helga Kuhse, uma enfermeira australiana, critica as publicações em torno da ética do cuidar, alertando para o risco de que se entendam como naturais as distinções entre homens e mulheres, 
de modo a justificar as diferenças de poder, especialmente no trabalho em saúde. Afirma que as distinções observadas por Gilligan são engendradas socialmente e que as enfermeiras, tradicionalmente tidas como "mães substitutas" e "soldados obedientes", hoje, em uma moldura semelhante, são vistas como as defensoras dos direitos e do bem-estar dos pacientes. Para ela, essa configuração oculta as assimetrias de poder nas relações de trabalho no setor Saúde, pois o trabalho de enfermagem é pontuado por situações de subserviência e de violência moral naturalizadas por um discurso da diferença. Exemplos disso estão presentes em diversas situações que demandam uma decisão ética, e não exclusivamente técnica. Com efeito, Kuhse, por exemplo, defende que enfermeiras e enfermeiros devem ter maior autoridade profissional não só para prescrever cuidados paliativos, mas também para prescrever ordem de não ressuscitar, facilitar o suicídio assistido e a eutanásia ativa (Kuhse \& Singer, 1998).

Em suma, pode-se pensar numa ética do cuidar que proponha uma ideia de cuidado emancipadora, baseada em uma profunda compreensão das diferenças morais em genuíno respeito à autonomia de quem cuida e de quem é cuidado. Respeitar a autonomia de profissionais da saúde e de pacientes implica um profundo respeito à existência humana.

A ética do cuidar pressupõe relações humanas no interior das equipes de saúde que respeitem as especificidades técnicas de cada profissional e promovam a reflexão sobre as questões morais de forma aberta e igualitária, condições indispensáveis para que seja possível construir consensos nas situações concretas em que os dilemas morais se apresentam. 
Um caso de emergência não é muito bom para ilustrar todas as possibilidades da ética do cuidar. Ainda assim, aplicada ao caso em debate, a identificação de todos os envolvidos e suas relações, e o envolvimento de todos nas tomadas de decisões poderiam levar ao surgimento de alternativas de manejo da situação ainda não pensadas. Alguém que adote a perspectiva do cuidado para tomar a decisão no caso do dr. Arnaldo possivelmente se recusaria a fazer a opção entre os dois com base em critérios de justiça. Entendendo que pessoas vivem em famílias e que essas relações reais de cuidado não são imparciais, impessoais ou iguais, adeptos da ética do cuidado propõem um experimento para estimular a reflexão: 'Como tratar as pessoas na sociedade quando se imagina que todas são parentes?', ou, adaptando a proposição ao caso em questão: 'Como resolver o dilema do dr. Arnaldo quando se descobre (ou se considera) que ambos os pacientes são seus parentes?'.

\section{BIOÉTICA DA PROTEÇÃO}

A bioética da proteção, proposta originalmente na América Latina por Fermin Roland Schramm e Miguel Kottow (2001), é baseada na recuperação do conceito de ética, entendido em seu sentido mais arcaico: guarida, abrigo e proteção. A bioética da proteção traz a marca de uma bioética que nasce em países periféricos, com uma população empobrecida, com poucos recursos. Questiona especialmente o principialismo quando aqueles que o aplicam carregam nas tintas no princípio do respeito à autonomia. A exaltação da autonomia, quando se pensa nas populações desassistidas da América Latina, por exemplo, carece de sentido, pois nessas sociedades predominam relações 
profundamente assimétricas. Priorizar a autonomia dos sujeitos de pesquisa, por exemplo, em detrimento de outras obrigações morais sem levar em conta que esses sujeitos são pessoas com um grau de educação formal muito baixo, com problemas de acesso aos serviços de saúde, muito empobrecidos, vivendo em ambientes que expõem a saúde a riscos que seriam impensáveis em nações desenvolvidas da Europa, em países com baixo grau de formalização de regras, pode muitas vezes se configurar como uma exploração da vulnerabilidade desses indivíduos. Ou seja, com base em estratégias clientelistas e aproveitando-se do baixo nível de organização dessas populações, reforça-se a exploração, ainda que aparentemente se estimule sua autonomia. O que lhes falta para exercer sua autonomia pode ser dito em uma expressão paulofreireana - tornarem-se emancipados. O que queremos dizer é que haverá exploração da vulnerabilidade quando o argumento para a realização de uma pesquisa estiver baseado na autonomia individual de pessoas que não têm acesso a medicamentos, sequer a serviços de saúde. Nesse caso, uma população destituída de tudo não poderá ser encarada como livre para fazer escolhas como um americano médio ou um francês. A pessoa se submete a qualquer pesquisa se com isso ela obtiver atendimento.

A bioética da proteção entende que o contexto socioeconômico no qual se situa a população, marcado por grandes desigualdades, precisa ser levado em conta nas decisões de saúde pública nas quais a proteção da população mais suscetível ou descapacitada ou vulnerada deve ser a obrigação moral que orienta as ações. Colocar as desigualdades no centro da análise bioética, quando passamos a situações da assistência à saúde ou pesquisa, implica considerar as relações muito assimétricas entre as populações 
destituídas e os profissionais da saúde, o que significa afirmar a obrigação moral de proteger essa população. A proteção não deve ampliar desigualdades, mas o paternalismo típico assim o faz, por simplesmente impedir que as pessoas tomem as suas próprias decisões. Proteger significa considerar as desigualdades e usar todos os recursos para que as pessoas possam compreender suas situações e decidir segundo seus genuínos interesses, com o máximo de liberdade; significa compreender as situações de assistência e pesquisa imersas em conflitos de interesses que devem ser identificados e minimizados ativamente. Proteger significa contribuir para a emancipação de indivíduos e coletividades.

Neste ponto convém fazer uma distinção entre a bioética da proteção e o paternalismo. Embora seja possível compreender a proteção proposta por esta corrente como apenas uma versão 'branda' do paternalismo, a bioética da proteção não pode ser confundida com o paternalismo médico, que historicamente tem levado os profissionais a assumir decisões em nome dos melhores interesses dos pacientes. A proteção proposta não nega a autonomia dos sujeitos. Mas ao tratar de pessoas cujas capacidades de exercer a autonomia estejam prejudicadas, ela busca de fato (re)conquistar as condições necessárias para seu exercício. Enfocar as questões que permeiam o cotidiano da assistência à saúde significa pensar os dilemas e problemas éticos e propor soluções entre o paternalismo e a exploração da vulnerabilidade. Pode-se afirmar, portanto, que a proteção tem uma perspectiva emancipadora para os sujeitos.

A bioética da proteção foi proposta inicialmente como um referencial teórico para a resolução de díspares problemas bioéticos, especialmente no campo da saúde pública - preconizando-se 
a implementação de políticas embasadas em um "princípio de proteção" (Schramm \& Kottow, 2001: 949) -, ainda que se possa também mencionar as questões atinentes ao início da vida, ao fim da vida, à ética em pesquisa envolvendo seres humanos e aos limites da biotecnociência (Schramm, 2005b).

\section{OUTRAS CORRENTES}

Existem outros marcos conceituais da bioética contemporânea que oferecem um arsenal teórico e metodológico, os quais, apesar de úteis para a apreciação dos problemas morais - como o caso do dr. Arnaldo -, deixamos de apresentar aqui pelas limitações de espaço que uma publicação como esta impõe. Faremos referência a eles ao final do livro, quando apresentaremos algumas sugestões de leituras complementares. Referimo-nos especialmente à bioética liberal, apresentada por Hugo Tristram Engelhardt Jr.; à ética deontológica, tão importante para o nosso campo inclusive por causa dos códigos de ética profissionais, fundamentada nos trabalhos do filósofo Immanuel Kant. Fizemos referência também à ética das virtudes, em geral associada ao pensamento de Edmund Pellegrino e David Thomasma; e à chamada casuística, cuja maior expressão é Albert R. Jonsen. Entre as formulações nacionais, não poderíamos deixar de registrar a chamada bioética da intervenção, desenvolvida por Volnei Garrafa, Dora Porto e seus colegas em Brasília, bem como a proposta, em construção, de Rodrigo Siqueira-Batista, um dos autores deste livro, de uma ética para todos os seres.

Cada uma das perspectivas discutidas neste capítulo gera argumentos diferentes, mas nem sempre dão suporte a decisões diferentes. $\mathrm{O}$ caso aqui proposto constitui um verdadeiro 
dilema, pois nele não se pode, em princípio, estabelecer qual é a decisão mais correta. A maioria dos indivíduos - racionais e razoáveis - seria capaz de dizer que a decisão do dr. Arnaldo é extremamente difícil e que há bons argumentos a favor e contra a decisão anunciada. É justamente na construção desses argumentos que cada uma das correntes aqui apresentadas, como exemplos, poderá contribuir. 
3 - Bióética e a Tomada de Decisões: entre a CLínica e a saúde pública

\begin{abstract}
A tomada de decisões é um dos aspectos centrais da prática clínica. Nesse âmbito, uma das principais preocupações dos envolvidos - especialmente os profissionais da saúde - nos processos decisórios cotidianos é como saber que a decisão tomada é a mais adequada, a mais correta para o paciente, considerando-se que esta adequação não significa apenas uma pertinência técnica, científica, mas a promoção do bem para o paciente. Esse bem para o paciente precisa ser considerado na perspectiva do próprio e levando-se em conta as suas concepções, mas não só. De fato, não se trata tão-somente de acatar o que o paciente deseja, ou seja, em nome de supostamente respeitar a autonomia do indivíduo, transferir para ele a responsabilidade pelas decisões tomadas. Não! Trata-se de uma reestruturação da relação médicopaciente (ou qualquer outro profissional da saúde-paciente) em outras bases, e não mais na noção preconcebida de que é um dever moral do profissional tomar as decisões em nome de seus pacientes, mas na inserção desse encontro em outra dimensão: aquela própria da saúde pública.

Isso não se configura, necessariamente, como uma novidade para a maioria dos profissionais da saúde, mesmo para aqueles dedicados à clínica individual. Consideremos, por exemplo, o atendimento a um indivíduo vítima de uma doença infecciosa transmissível. Nenhum profissional da saúde, com uma formação
\end{abstract}


no mínimo razoável, descuidará das orientações e cuidados em relação ao controle do contágio e dos procedimentos necessários para assegurar que a moléstia não se dissemine, ainda que apenas entre a família do enfermo. Fazer isso - por exemplo, diagnosticando tuberculose em um indivíduo e deixando de investigar os demais membros de sua família e de orientá-los com medidas de proteção - é inaceitável para uma boa prática profissional em seus aspectos científicos (clínicos e de saúde pública) e bioéticos, ainda que esta discussão raramente se dê em termos morais, por ser aparentemente restrita ao âmbito técnico.

Por que apenas aparentemente? Porque, de fato, tais preocupações representam, em última análise, uma atitude de cuidado em promover o bem para outras pessoas ou, pelo menos, evitar-lhes o mal. Mas são preocupações, e procedimentos, já integrados à prática médica, que em geral não são justificados moralmente, mas apenas tecnicamente. Essa situação não é a ideal, pois é sempre preferível e desejável que haja plena percepção e compreensão das dimensões de um dado problema. Mas, o que torna significativa essa dimensão do coletivo, inerente a qualquer encontro clínico, a qualquer adoecimento individual, é que ela precisa ser destacada e trazida novamente para o foco das atenções. Se, como Michel Foucault tão bem analisou em seu livro Microfísica do Poder, a moderna medicina nasceu social e em contraponto às antigas compreensões individualistas sobre o processo de adoecimento, muitas dessas percepções foram sendo menos enfatizadas ao longo do século XX. Embora atualmente não haja muitas dúvidas sobre os determinantes do processo saúde-enfermidade, esse saber só costuma ser discutido nas escolas da área da saúde nas disciplinas de saúde coletiva. Profissionais ligados à clínica 
insistem em discutir o adoecimento como um fenômeno estritamente individual.

São reconhecidos hoje quatro grupos principais de fatores que determinam o estado de saúde de um indivíduo: biológicos, ambientais, assistenciais e relacionados com o seu estilo de vida. Em uma rápida caracterização, é razoável reconhecer entre os fatores biológicos os caracteres genéticos, étnicos, o sexo e a idade. Entre os fatores ambientais reconhecem-se as condições físicas e biológicas - estas últimas caracterizadas pelos organismos que coabitam o ambiente - e os fatores socioeconômicos, incluídos aqui tanto as características da ocupação profissional do indivíduo e as condições nas quais este trabalho é exercido como o salário, proventos diretos e indiretos e outros eventuais benefícios sociais. O terceiro determinante é a assistência - ou, em termos mais amplos, o cuidado - oferecida à saúde individual, tanto no campo da prevenção e da promoção da saúde como no da terapêutica e da reabilitação. Por fim, o último grupo de determinantes a ser considerado é o que ainda traz alguma polêmica associada: os fatores relacionados com o estilo de vida do indivíduo. A polêmica, entretanto, não está relacionada a alguma dúvida sobre se o estilo de vida está entre os determinantes do estado de saúde de um indivíduo, mas às consequências de reconhecer tal relação. Antes, vejamos quais são os componentes desse determinante: hábitos, vícios e abuso de drogas ou de substâncias reconhecidamente nocivas à saúde e ao bem-estar individuais; a qualidade e o tipo de alimentação que o indivíduo ingere diária e/ou regularmente; a quantidade, oportunidade e qualidade do lazer de que ele desfruta regularmente (Siqueira-Batista et al., 2008). Assim, o que alguns têm questionado é a pertinência, ou justiça, de os sistemas 
públicos de saúde assumirem responsabilidades pelo tratamento de indivíduos cujo estilo de vida esteja associado a riscos para a própria saúde. Por exemplo: um tabagista crônico, conhecedor dos riscos associados ao seu hábito (ou vício, a distinção não é relevante neste caso), deve ou não ser atendido gratuitamente para o tratamento de enfermidades diretamente relacionadas com o seu hábito/vício por um sistema público naturalmente sobrecarregado? Da mesma forma que o tabaco, outros (maus) hábitos são citados, como a ingestão de alimentos ricos em colesterol para os portadores de doenças cardiovasculares, açúcar para os diabéticos, e assim por diante.

Por outro lado, esses questionamentos proporcionam também uma reflexão mais ampla sobre de que forma as injustiças sociais se refletem nos indicadores de saúde. Margareth Whitehead (1990) propôs um conceito - hoje amplamente aceito - para o reconhecimento de quando as diferenças observadas nesses indicadores são fruto de iniquidades, ou injustiças. Todas as diferenças entre o melhor e o pior desempenho nos indicadores dos diferentes grupos socioeconômicos constituem iniquidades em saúde. Essas diferenças são não apenas desnecessárias como também evitáveis e consideradas injustas no contexto geral do conhecimento etiológico e de relações sociais. Mas nem toda diferença é, de fato, injusta. Assim, Whitehead (1990) identifica como determinantes de diferenças não injustas em saúde a variação biológica, natural entre diferentes pessoas; o comportamento danoso à saúde que é livremente escolhido por determinados indivíduos, tal como a participação em certos esportes e passatempo, como paraquedismo ou outras atividades radicais, por exemplo; e a vantagem transitória de saúde de um grupo que tenha adotado em primeiro 
lugar comportamentos promotores de saúde em relação a outros grupos (desde que esses outros grupos tenham meios para adotar tais comportamentos dentro em breve).

Já os determinantes não apenas de desigualdades, mas também de injustiças na saúde são: o comportamento danoso à saúde, no qual o grau de escolha de estilos de vida é severamente restrito; a exposição a condições de vida ou de trabalho insalubres ou estressantes; o acesso inadequado a serviços essenciais de saúde e outros serviços básicos; a seleção natural ou mobilidade social associada à saúde e relacionada com a tendência de que as pessoas doentes desçam na escala social.

É claro que esses determinantes oferecem uma variação enorme de situações, todas de grande complexidade, que tornam o esforço por ser justo em uma ação de saúde uma tarefa bastante difícil. Tomemos um exemplo: a questão dos transplantes, procedimentos capazes de salvar vidas. Como não existem órgãos suficientes para realizar transplantes em todos os pacientes que poderiam se beneficiar dessa tecnologia, é preciso estabelecer um critério que determine quem se beneficiará em primeiro lugar. A solução adotada já há algum tempo em todo o mundo é a fila. Todos os que poderiam se beneficiar entram em uma fila, e a ordem de chegada é o critério com o qual se acredita garantir um processo justo de escolha. Mas, como visto, o acesso aos serviços de saúde é uma das causas de injustiças! Todos sabem que existe, no Brasil e em boa parte dos países, uma diferença marcante no acesso a serviços de saúde. Quem tem condições de pagar por um serviço particular - ou ao menos conveniado com empresas de medicina de grupo - tem acesso muito mais rápido a uma consulta médica do que alguém que dependa do cuidado oferecido em unidades 
públicas de saúde. Some-se a isso o acesso aos serviços de apoio diagnóstico, e fica fácil ver que ainda que duas pessoas, com a distinção aqui assinalada, começassem a se sentir mal no mesmo dia e acabassem recebendo o mesmo diagnóstico e a mesma proposta terapêutica - transplante -, os momentos cronológicos de entrada na fila do transplante seriam muito diferentes. A diferença estaria determinada não apenas pela desigualdade no acesso ao serviço de saúde propriamente dito, mas também pelo fato de que os que têm maior dificuldade no acesso acabam por protelar a procura por serviços de saúde, sabedores das dificuldades que enfrentarão. Assim, suas dificuldades são dobradas e injustas. Como, então, buscar uma ação mais justa?

Tendo, ao menos declaradamente, a questão da justiça como foco, foi bastante discutido no meio médico o problema da elevada mortalidade na fila dos transplantes. Argumentava-se que essa elevada mortalidade decorria da utilização do tempo de ingresso na fila como o único critério para o acesso ao transplante, fazendo com que pessoas com quadro clínico mais grave perdessem a oportunidade de se salvar por terem entrado tardiamente na fila. Sem dúvida um bom argumento. Assim, passou-se a utilizar, em 2006, um método chamado Meld (Model for end-stage liver disease, modelo para doença hepática em estágio final). Esse método determina que o transplante seja realizado no paciente em estado mais grave; a gravidade é determinada mediante uma complicada fórmula matemática que, para seus defensores, confere ao método a objetividade que se deseja. Entretanto, há ainda grande imprecisão e muitas incertezas em relação à validade de seu uso. Um mesmo estudioso do tema, em artigos publicados com menos de um ano de diferença, apresenta informações 
contraditórias. No primeiro artigo (Ferraz-Neto, 2006), ele relata que a mortalidade em lista de espera, que deveria diminuir, bem como os resultados de sobrevivência, que deveriam melhorar, são contraditos pelos dados então disponibilizados pela Secretaria de Estado da Saúde de São Paulo, que demonstram o contrário. Já no ano seguinte (Ferraz-Neto \& Afonso, 2007), ele reconhece que o Meld estima, com relativa precisão, o risco de morte da maior parte dos pacientes, o que significa também reconhecer que o método não contempla uma parcela não irrisória destes, dos quais não prevê corretamente a gravidade da condição clínica. No mesmo artigo os autores dizem que a análise de justiça de uma ação terapêutica seria "a oferta do melhor recurso disponível para o indivíduo em questão, independentemente do resultado obtido", enquanto "a 'utilidade' estaria definida pela melhor utilização dos recursos disponíveis e limitados, frente às necessidades da sociedade como um todo, apoiado no resultado coletivo obtido" (Ferraz-Neto \& Afonso, 2007: 169). Para John Harris (1975), filósofo inglês, dadas as diferenças de acesso e as múltiplas injustiças, não é possível que a escolha do receptor seja efetivamente justa e, portanto, a única forma de se alcançar um grau aceitável de justiça seria o que ele chamou de "a loteria da sobrevivência". Ou seja, como o acesso aos serviços de saúde depende do próprio nível socioeconômico, é grande a possibilidade de que tal acesso jamais seja igual entre dois indivíduos, especialmente quando são de estratos sociais diferentes. Øverland (2007), por sua vez, reavaliou a proposta de Harris e identificou três tipos possíveis de loteria. O primeiro tipo, que ele chamou de "nacional", incluiria todas as pessoas de uma determinada jurisdição, que poderiam ser sorteadas para doar ou receber um 
órgão, independentemente de serem doadoras ou de necessitarem do órgão. O segundo tipo, que chamou de "loteria de grupo específico", incluiria apenas os membros de um grupo que teriam como característica a mesma probabilidade de apresentarem, em algum momento, a falência de um órgão. O terceiro tipo, chamado de "loteria local", consistiria no sorteio entre indivíduos que já apresentam a necessidade de um novo órgão, mas guardam a característica de serem compatíveis e necessitarem de órgãos diferentes. Ele descarta o primeiro tipo, por considerar que a injustiça relacionada com a proposta seria difícil de contornar, e o segundo por considerá-lo irrealizável com o necessário controle das possíveis conseqüências indesejáveis. Defende, portanto, a possibilidade de se fazer o sorteio entre os indivíduos que já sejam candidatos a um transplante e compatíveis com um eventual órgão que esteja disponível. Assim, todos se equivaleriam e a sorte definiria qual deles receberia o órgão. Embora essa possa parecer uma alternativa justa (e efetivamente parece ser), não nos parece razoável delegar à sorte, ou ao azar, a definição desses casos. Entendemos que os profissionais que detêm essa responsabilidade de tomar a decisão não podem abrir mão de, com os melhores recursos de que dispõem, fazê-lo. Mas é claro também que essa tomada de posição não pode ser solitária.

A necessidade de avaliar que decisão é a mais justa em uma situação dada, considerando a justiça seja como condição prévia, seja como o fim último, é uma questão que se apresenta aos profissionais da saúde com frequência cada vez maior em contextos bastante variados. Surge, por exemplo, em situações em que é necessário escolher quem receberá os escassos recursos disponíveis 
para determinadas circunstâncias, seja um respirador, um stent, um cateter. Para complicar esse cenário, os cursos de graduação da área da saúde não estão preparando seus estudantes para lidar com essa realidade. $\mathrm{Na}$ verdade, acostumam seus discentes ao ambiente do hospital universitário e à obediência automática, de forma acrítica, a normas e regras que muitas vezes nem estão escritas nos códigos deontológicos, mas correspondem apenas a uma relativização moral ou a um corporativismo simplista. E, de repente, esse ex-aluno se encontra, recém-saído da escola, em uma unidade de saúde, tendo que decidir quem receberá um recurso e sem contar com o instrumental analítico capaz de ajudá-lo a fazê-lo. Esse é um aprendizado extremamente importante - como reconhecido nas diferentes diretrizes curriculares nacionais para os cursos de graduação da área da saúde -, esquecido em muitas estruturas curriculares. Como fazê-lo, eis a questão. Apresentaremos, em seguida, alguns apontamentos sobre o problema.

\section{A QUESTÃO DO MÉTODO E dO ARGUMENTO}

A avaliação de um problema moral é um aspecto fundamental para todos os envolvidos no cuidado da saúde. Assim como a clínica se vale da semiologia como ponto de partida essencial para a realização do diagnóstico e orientação da terapêutica, também a ética possui suas próprias ferramentas. Mas a relação entre a teoria ética e a bioética não é linear. Não se trata, como assinalou Rachels (1998), de simplesmente tomar a teoria ética como um ponto de partida e então aplicá-la ao caso em questão para chegar à conclusão sobre o que deve ser feito. Ao contrário, uma boa analogia para se entender essa relação entre a bioética e as teorias éticas é a relação entre biologia e medicina (Rachels, 
1998). O autor cria uma analogia fazendo referência a uma suposta médica que não saiba nada de biologia, mas aborda seus pacientes com o espírito de um mecânico de carro com uma caixa de ferramentas de técnicas práticas. Essa médica seria capaz de fazer um trabalho aproveitável. Mas ela não terá tantos recursos quanto uma colega que conheça as ciências relevantes. A diferença aparecerá quando um novo problema ou um problema capcioso surgir, requerendo mais do que a simples aplicação das técnicas já familiares. Para lidar com esses casos difíceis, ela pode se dedicar a pesquisas científicas para auxílio, ou mesmo dedicar-se temporariamente a pesquisas mais fundamentais. E o que ela aprender desses casos que encontra em sua prática, por sua vez, pode ter significância para o futuro desenvolvimento da ciência.

A bioética não opera independentemente da teoria ética; mas também não é a simples 'aplicação' de uma teoria a casos particulares. Há uma inter-relação entre a teoria e o estudo do caso que beneficia a ambos. Assim, para se lidar com casos que apresentem questões morais conflituosas concretas, torna-se necessária uma abordagem não dogmática. Ademais, a partir da abertura ao conjunto de contribuições das diversas tradições, podem surgir argumentos que fundamentem ações concretas que sejam aceitáveis pelos sujeitos morais envolvidos e contribuam para o desenvolvimento dos processos necessários à solução dos problemas.

Assim, embora existam algumas propostas metodológicas publicadas na bibliografia especializada, não as apresentaremos aqui por entendermos ser mais apropriado oferecer a estrutura geral de reflexão e de caminhos, sem nos restringirmos a alguma 
delas especificamente. Nossa proposta, neste momento, é elaborar uma breve síntese que deverá atender às necessidades iniciais do debate, auxiliando na melhor compreensão das questões bioéticas clínicas, como problemas concretos sobre os quais o profissional da saúde, individual ou coletivamente, terá de se posicionar - incluindo a tomada de decisões.

Antes de apresentarmos essa abordagem genérica, é importante destacar algumas questões prévias afeitas ao universo teórico da ética e totalmente relacionadas com a tomada de decisão. Trata-se de algo que Schramm (2003) abordou no texto "Acerca de los metodos de la bioética para el análisis y la solución de los dilemas morales", o qual embasa, amplamente, esta parte de nossa argumentação. Esse artigo traz uma discussão sobre a racionalidade da argumentação em bioética, que pressupõe: “a) ter clareza sobre as abordagens descritivas e a compreensão dos conflitos; b) fazer uma abordagem dedutiva e indutiva do raciocínio que pretenda legitimar uma decisão; c) fazer uma abordagem pragmática da relação entre os meios, fins e agentes envolvidos”, os quais devem avaliar os efeitos da decisão em pauta (Schramm, 2003: 60). A proposta de Schramm é ao mesmo tempo racionalista e pragmática. Isso é muito importante para a presente análise, posto que expressa a preocupação de atender a uma questão racional e outra prática. Ou seja, não basta que uma reflexão seja correta do ponto de vista argumentativo e teórico, pois ela deve ser também aplicável. E para que um argumento seja classificado como racional, ele deve cumprir uma série de requisitos. Deve deixar claro que termos serão utilizados e o que se pretende, por exemplo. Deve também ser encadeado de forma compreensível e consistente, estabelecendo a devida relação entre o raciocínio 
e a conclusão da argumentação. Não é possível apresentar uma série de argumentos e, ao concluir, chegar a observações não coerentes com o que se apresentou antes. É muito importante que o argumento não se contradiga. Ele deve obedecer ao que se chama de "princípio da não contradição".

Deve-se cuidar para que argumento que será usado para defender determinada proposta contemple o aspecto comunicacional, isto é, assegurar que ele seja de fato compreendido por todos os agentes morais envolvidos, apropriadamente fundamentado e não contraditório. É preciso desenvolver e apresentar argumentos que sejam, ao mesmo tempo, consistentes e imparciais. Isso não é o mesmo que buscar descobrir a verdade, mas sim buscar encontrar a melhor solução para um determinado problema moral, a qual seja aceitável pelos envolvidos na disputa.

Mas, além dessa conformidade com a razão teórica, é mister atender aos requisitos da razão prática. Entre as ferramentas que ajudam nessa análise, reconhecem-se as seguintes (Schramm, 2003):

- Intuição: útil em geral no início do raciocínio moral, ajudando na identificação de situações contraintuitivas (que, quando reconhecidas, devem ser reavaliadas com outros recursos).

- Razoabilidade: necessária para se verificar a aplicabilidade de determinada decisão em todos os âmbitos; significa perguntar se a conclusão a que se chegou é ou não razoável, pois no caso de não ser razoável ela terá pouca relevância prática.

- Exemplificação, ou seja, a busca de exemplos concretos que possam proporcionar maior objetividade ao argumento. 
- Analogias, que servem tanto para reforçar quanto para rechaçar alguns argumentos; muitas vezes as analogias são usadas em situações extremas para demonstrar os limites ou possibilidades de determinada argumentação.

- O argumento da 'ladeira escorregadia': usado para identificar as possíveis consequências de determinada decisão; um problema na utilização desta ferramenta é o entendimento equivocado de que determinada consequência seja inevitável e diretamente provocada, quando ela é apenas uma entre diversas consequências possíveis.

- O interlocutor 'advogado do diabo', que Schramm considera mais útil nos casos em que é preciso refletir sobre os seus próprios argumentos: consiste em dialogar com um interlocutor imaginário imparcial que buscará argumentos válidos contrários aos que você está apresentando.

- A busca de compromisso, que derivaria do objetivo de encontrar em cada situação de conflito uma solução pacífica e, na medida do possível, diplomática.

A busca de compromisso pode ser entendida como a procura por um entendimento efetivo entre as partes envolvidas. Para tal, o diálogo a ser estabelecido deverá inicialmente reconhecer o outro, seu interlocutor, como um legítimo outro. $\mathrm{Ou}$ seja, uma pessoa que tem total legitimidade na disputa em questão, e não alguém que deva ser convencido sobre as posições adotadas. A idéia é identificar, por meio do diálogo, que é possível alcançar a convergência. Para tanto, é indispensável que todos os interlocutores estejam de fato comprometidos com tal entendimento e com a busca pelo que bem comum. Isso será tão válido quanto entender que os interesses deste ou daquele não 
têm precedência sobre os interesses do outro, pois caso contrário essa suposta igualdade deixa de ser legítima. Em situações clínicas, nas quais muitas vezes é possível reconhecer desequilíbrios e assimetrias nas relações, há especial dificuldade em obter tal comprometimento.

\section{UMA ABORDAGEM PRÁTICA DOS PROBLEMAS MORAIS NA CLÍNICA}

A análise de problemas morais relacionados com a prática clínica pode ser tanto retrospectiva quanto relativa a um problema que está ocorrendo no exato momento em que a avaliação é demandada. A necessidade de apreciar um problema e tomar decisões na clínica representa uma pressão constante para os profissionais da saúde e, em especial, para aqueles que têm maiores responsabilidades relativas à decisão tomada. Nem sempre é possível parar para discutir o caso e, então, tomar a decisão considerada pelo coletivo como a mais adequada. Em muitas oportunidades, há situações em que a vida ou a morte de um indivíduo ou as possibilidades de sequelas graves para ele serão decididas em poucos segundos. Reanimar ou não reanimar um paciente quando não se sabe nada sobre ele ou sobre as possibilidades de sobrevivência? Até quando investir na reanimação de um neonato? Quem deverá se beneficiar de um recurso terapêutico escasso ou único? São decisões tomadas diariamente e que precisam ser melhor fundamentadas. É certo que tais situações requerem dos profissionais reflexões prévias (individuais e coletivas) e um diálogo precoce e permanente com o paciente e seus familiares. Outras situações, entretanto, não ocorrem em contextos de emergência - cujo paradigma é a parada cardiorrespiratória -, 
mas permitem esperar até mesmo semanas antes de qualquer tomada de decisão.

Para a boa análise da situação em questão é indispensável que haja informação adequada sobre a situação clínica concreta e que os dados obtidos se atenham, inicialmente, aos fatos e se baseiem na melhor informação disponível. Um grande esforço deve ser feito, nessa fase inicial, para não 'contaminar' o relato com os valores dos profissionais, quer ideológicos, religiosos ou de outra natureza. Por outro lado, é preciso grande cuidado com a ilusão de que a ciência terá todas as respostas, o que é, evidentemente, uma falácia. O conhecimento da ciência biomédica é probabilístico, e suas conclusões devem ser compreendidas dentro desse limite. As informações médicas, entretanto, não devem se restringir ao que os exames clínicos e complementares oferecem e muito menos à visão que os médicos têm da situação. O paciente, como qualquer indivíduo, não pode ser visto nem compreendido fora de seu contexto social, necessariamente incluído como parte inseparável do quadro clínico - eis mais uma ponte possível entre clínica e saúde pública. Dentre as informações que se deve obter, estão, por exemplo: o paciente é religioso? Qual a sua atividade profissional? Quais os seus hobbies? Como é a sua família? Como é a relação dele com a família? É o provedor da família?

Em seguida, deve-se proceder à clara identificação das questões morais envolvidas no caso e sua relevância. Para tal, devemse conhecer, também, quais são as partes interessadas no caso, e tal identificação não deve ser restritiva. Ao contrário: é igualmente importante buscar compreender as relações existentes entre esses legítimos interessados, dando bastante atenção ao fato de 
que nem sempre os interesses estão claramente apresentados ou admitidos.

Deve-se, então, procurar identificar uma série de pontos que ajudarão na análise da situação e do seu contexto, visando ao desenvolvimento e à apresentação do argumento. Dentre os pontos que deverão ser incluídos em sua análise estão a identificação específica dos valores em conflito, bem como dos diferentes pontos de vista implicados (aqui entendidos os argumentos que fundamentam cada uma das posições em questão ou em conflito). É preciso procurar também identificar se estão em jogo apenas interesses individuais, buscando verificar se existem interesses da coletividade em geral a serem considerados, bem como se a decisão pode envolver aspectos relacionados com a justiça sanitária. Não se poderá deixar de realizar uma clara identificação de todos os benefícios potenciais de cada uma das alternativas, bem como a dos riscos de danos, lembrando sempre que existe a tendência humana a sobrevalorizar a possibilidade de benefícios e a minimizar os riscos. Ainda no campo dos riscos de danos, é preciso identificar todas as potenciais vítimas de danos, ponderando-os, e não apenas aqueles diretamente relacionados ao caso. Outro aspecto que não pode ser negligenciado são as possíveis consequências financeiras da decisão, o que obriga a compreender adequadamente o funcionamento e o financiamento do sistema de saúde para considerar apropriadamente as possíveis repercussões nas finanças de uma família, no caso de um atendimento no sistema privado de saúde.

Algumas pessoas acreditam que nesse processo de buscar elementos para fundamentar sua posição é útil se perguntar sobre qual seria a posição assumida por uma pessoa que considerassem 
virtuosa. Ou seja, tentar identificar qual seria a opinião de uma pessoa que age tomando como fundamento para sua ação a ética das virtudes.

Como dito antes, é interessante e útil, para esclarecimento do contexto, comparar a situação atual com outros casos semelhantes que sejam do conhecimento dos envolvidos, buscando identificar o que torna os casos semelhantes e diferentes e avaliar as consequências da decisão tomada anteriormente.

Após tais apreciações, torna-se essencial examinar as alternativas existentes e as razões que podem fundamentar esta ou aquela decisão. Devem-se buscar diferentes pontos de vista éticos, com as diferentes fundamentações apresentadas no Capítulo 2, em busca da decisão mais bem fundamentada. É preciso, então, proceder ao apelo à razão prática: essa decisão é razoável? Ela contraria alguma regulamentação ou dispositivo legal ao qual os protagonistas devam obedecer? Aqui é necessário fazer uma breve pausa para um comentário sobre a relação entre a ética e o direito (ver também o Capítulo 1). Embora se deva, evidentemente, obediência às leis e a alguns dispositivos regulamentares infralegais, o tempo necessário para que uma lei seja modificada muitas vezes é tão grande que a sociedade adota e aceita mudanças comportamentais que a lei ainda não expressa. Por isso, o moderno direito não se pauta pelo seguimento estrito da letra fria da lei, mas a interpreta à luz dos tempos em que as análises estão sendo feitas. O indispensável é que haja bons e sólidos argumentos, e que se vá além da interpretação estrita do que está redigido; ademais, em algumas situações não há previsão legal, ainda que a decisão deva ser tomada, o que torna a aprendizagem da argumentação ética/bioética e da tomada de decisão extre- 
mamente relevante. Tendo sido utilizadas todas as ferramentas julgadas necessárias para uma adequada avaliação e formulação de recomendações para a ação, é importante proceder a mais uma análise de factibilidade e adequação, perguntando a si próprio se a conclusão a que se chegou é confortável para si mesmo - ou seja, se poderia ser tornada pública, se poderia ser assumida perante as pessoas que se tenha em alta conta, seja técnica, seja moral, como um mentor ou os próprios familiares.

\section{DECISÕES NA PRÁTICA CLÍNICA}

Existem diversas questões e temas que requereriam uma abordagem específica, ao menos uma apreciação inicial, que colaborassem para o desenvolvimento de reflexões particulares. Mas será preciso restringi-las, com base, em grande medida, em sua relevância e na frequência com que os problemas surgem na prática.

\section{A tomada de decisões em nome de terceiros}

A tomada de decisões em nome de terceiros é aquela em que é preciso questionar se a opinião da família deve prevalecer sobre a do paciente. A autonomia de um indivíduo diz respeito à sua capacidade de autodeterminação e o respeito à autonomia não deve e nem pode ser compreendido apenas como a obtenção, seja na pesquisa, seja na clínica, do consentimento livre e esclarecido para a realização de procedimentos ou de experimentações. O consentimento é, sem dúvida, uma das formas pelas quais o respeito à autonomia poderá se evidenciar, mas esse respeito é algo mais complexo, pois requer o reconhecimento do outro como sujeito moral, ou seja, capaz de avaliar e 
decidir sobre questões morais, especialmente aquelas que lhe concernem. Entretanto, em várias situações o respeito ao direito de cada indivíduo decidir o que será feito consigo mesmo em uma situação de necessidade de cuidados de saúde - não trataremos, aqui, das situações de pesquisa - é questionado ou colocado em dúvida.

Algumas pessoas têm, reconhecidamente, essa capacidade de autodeterminação diminuída ou ausente, transitoriamente ou não.

- O primeiro grande exemplo são as crianças - cuja capacidade de compreender determinadas situações será, em geral, proporcional à sua idade e desenvolvimento cognitivo e emocional. Todavia, mesmo com crianças deve-se oferecer informações, na medida de sua capacidade de compreensão, e buscar obter seu assentimento para os procedimentos a serem realizados. Não utilizamos o termo 'consentimento' porque este requer não apenas a capacidade de autodeterminação como também a capacidade legal. $\mathrm{O}$ assentimento, ou a concordância ou aquiescência, para crianças tem um valor moral, não legal. A chamada declaração sobre direitos do paciente, conhecida como Declaração de Lisboa, da Associação Médica Mundial, cuja primeira versão é de 1981, já preconizava o assentimento dos legalmente incapazes em geral. O próprio Estatuto da Criança e do Adolescente brasileiro determina que crianças e adolescentes devem ser ouvidos em diferentes situações de seu interesse e, é claro, a lei não determinaria que eles sejam ouvidos apenas para que ouçamos o som de sua voz, mas para que suas opiniões sejam levadas em consideração seriamente. Assim, podemos compreender que, para o legislador brasileiro, o assentimento traz em si a ideia de respeito às posições das crianças e adolescentes. 
- Em relação aos pacientes com distúrbios mentais há uma compreensão, equivocada, de que, por sua enfermidade, eles não teriam capacidade de autodeterminação, em função de sua condição emocional. Essa é uma verdade em termos: alguns pacientes com determinadas condições, sejam agudas ou crônicas, podem ter sua autonomia diminuída, mas não se deve generalizar, e sim avaliar caso a caso.

- As situações como aquelas em que o paciente está inconsciente expõem claramente um perigo à possibilidade de exercício da autonomia, de modo que as decisões terão de ser tomadas por terceiros. Mas é com grande frequência que profissionais da saúde consideram seus pacientes incapazes de decidir sobre suas vidas e tomam decisões em seus nomes quando estes apresentam plena capacidade de decidir por si mesmos. Parece claro que a motivação, possivelmente, na maioria das vezes, é nobre - por exemplo, pela beneficência -, mas é também muitas vezes uma manifestação de ignorância, de preconceito e de desconsideração com o seu paciente.

- Há também as situações nas quais os familiares solicitam que não sejam comunicados, aos seus entes queridos que se encontram enfermos, seus diagnósticos ou mesmo prognósticos. Mais uma vez não se questionam, aqui, as intenções, as quais podem ser reconhecidas como as mais sinceras e altruístas; a questão é que, com seu temor de provocar sofrimento adicional, os parentes podem privar seu ente querido de satisfazer desejos finais ou de escolher de que forma deseja viver seus momentos finais. Então, quem deve decidir? A orientação é de só desrespeitar o direito de um determinado paciente a escolher o que quer para a sua própria vida caso haja muito boas razões e elas sejam sempre elaboradas e ratificadas, como já discutimos neste capítulo. 
A condição do paciente no momento do atendimento

As condições clínicas em que um paciente se encontra quando da realização do atendimento são outro ponto que merece consideração especial.

$\mathrm{O}$ atendimento realizado em situações de emergência e urgência difere de forma bastante substantiva daquele realizado em situações nas quais o atendimento pode ser postergado por várias horas ou dias, sem que com isso aumente o risco de morte ou de incapacidades. Os profissionais encarregados do cuidado em tais circunstâncias precisam ser muito bem preparados tecnicamente não apenas para atuar nas dramáticas situações, como também para lidar com os aspectos morais a elas relacionados que não oferecem tempo para detalhada consulta entre colegas. As decisões são tomadas em um curto intervalo de tempo e precisam ser o resultado de uma reflexão adequada, o que em geral demanda uma ponderação prévia, a qual permitirá ao profissional uma apreciação mais rápida da situação em questão.

As condições dos pacientes atendidos nas salas de emergência de hospitais podem ser classificadas como: rotina, quando o tratamento pode ser retardado em várias horas ou dias sem que haja aumento do risco de morte ou de incapacidade; urgência, quando o tratamento precisa ser iniciado em poucas horas, pois existe risco de evolução para complicações mais graves e mesmo fatais; e emergência, quando a necessidade de manter as funções vitais ou evitar incapacidade e complicações graves exige que o início do tratamento seja imediato. Outra condição que precisa ser mencionada é a situação de parada cardíaca ou respiratória, quando medidas de reanimação devem ser imediatas. 
Um atendimento de emergência é diferente do atendimento eletivo, na medida em que o exame clínico precisa reconhecer prioridades tendo em vista a detecção, em tempo útil, dos distúrbios que ameaçam a vida. Na medida em que tais disfunções vão sendo identificadas, elas têm de ser tratadas. A ação inicial só se encerra quando o paciente se estabiliza.

O êxito do atendimento em urgências e emergências depende fortemente da competência técnica, pois se o diagnóstico for feito tardiamente é muito provável que a letalidade aumente. No caso de diagnósticos incorretos, ocorre não apenas o aumento da possibilidade da letalidade e de sequelas, mas também a má utilização de recursos. Nem sempre o diagnóstico é fácil, mesmo para profissionais experientes e competentes, o que só aumenta a responsabilidade dos que designam profissionais para atuar em emergências. $\mathrm{O}$ investimento na formação desse profissional é um reflexo da preocupação efetiva com a qualidade da assistência oferecida. Não é possível que a emergência seja a 'porta de entrada' de novos profissionais nos hospitais, tratada como um espaço permanente de formação e falta de experiência. Os gestores do sistema de saúde, público ou privado, precisam compreender e valorizar esse espaço, nele alocando profissionais especializados, com adequada experiência clínica, que saibam trabalhar em equipe - esta sim uma característica quase que mandatória para um bom profissional dos setores de emergência.

O primeiro ponto a ser destacado não diz respeito ao cuidado individual. É comum a crítica ao fato de que as emergências hospitalares e/ou prontos-socorros vivem superlotadas por casos que não são de fato de emergência ou urgência. Essa crítica é repetida com frequência e não está fundamentada em dados 
errados, embora isso possa parecer paradoxal, ou contraditório. Não é incomum que periódicos da imprensa leiga e mesmo profissionais da saúde mal informados responsabilizem a população que busca o atendimento nesses locais com condições clínicas não urgentes ou não emergenciais pela superlotação nessas unidades. Esse é um exemplo do que se chama 'culpabilização da vítima', a qual consiste em atribuir àqueles que são penalizados em uma determinada situação a responsabilidade por ela. Está claro que o sistema de saúde não oferece alternativas concretas para o cuidado das pessoas que adoecem de forma aguda e necessitam que o saber técnico os oriente e auxilie a superar a enfermidade. Mesmo o sistema privado com convênios está privilegiando a assistência hospitalar ou em clínicas, repetindo o modelo falido da organização pública. A eventual expansão da rede básica, entretanto, não necessariamente resolverá o problema, pois é preciso que ela seja resolutiva e não funcione apenas como um anteparo temporário para as pressões nas emergências.

Mas o desafio que se impõe aos profissionais encarregados do cuidado nessas unidades e nessas condições requer também que se questione, com toda a tenacidade possível, o preconceito. O descaso com essa população que procura os hospitais públicos, em suas emergências, para cuidar de seus males pode ser atestado pela alcunha com a qual esses pacientes são muitas vezes chamados - de modo profundamente desrespeitoso - no Brasil: "Pimba - pé inchado, mulambo, bêbado e atropelado". Nos ambulatórios ainda existem profissionais de humor duvidoso que se referem ao seu local de trabalho como "mulambatório". Não se trata de um fenômeno brasileiro: Konner (1987) informa que nas salas de emergência nos Estados Unidos os enfermos menos 
desejados, em geral hispânicos ou negros sem seguro saúde, são chamados de SPOS - subbuman piece of shit.

O código de ética do American College of Emergency Physicians (Acep, 2008) identifica algumas virtudes necessárias ao médico de emergência, as quais são válidas para todos os profissionais que atuam nesse setor. Propõe-se que tais virtudes não sejam vistas e entendidas como atributos a serem perseguidos, ou simulados, mas como virtudes ou características pessoais que favoreceriam um bem-estar nessas unidades. Não é qualquer pessoa que se adapta ao trabalho em uma emergência, pois são requeridas qualidades e habilidades especiais - não apenas técnicas, mas morais, emocionais e comunicacionais, entre outras. São elas:

- Coragem: habilidade de cumprir suas obrigações apesar do eventual risco pessoal ou perigo. Esses profissionais têm de lidar com empregadores altamente demandantes, policiais, aprendizes incompetentes, famílias que solicitam demais, criminosos, pessoas infectadas e administradores do sistema muitas vezes insensíveis às necessidades de pacientes com os quais eles jamais se confrontaram.

- Justiça: compromisso de dar a cada pessoa o que é devido a ela; a justiça ajuda os profissionais de emergência a racionalizar o uso de recursos, a serem parcimoniosos com a terapêutica e a refutar cuidados marginalmente benéficos em prol de um nível básico de cuidado para outros.

- Vigilância: profissionais da emergência têm de estar alertas e preparados para encontrar o imprevisível - incluindo as demandas incontroláveis -, apesar da desarmonia do ciclo de sono e vigília que afeta o seu próprio bem-estar. 
- Imparcialidade: todos devem ser tratados com dignidade, ainda que tenham comportamentos muitas vezes desagradáveis ou não sociais, ou simplesmente não agradem aos profissionais.

- Credibilidade: os pacientes chegam a uma emergência doentes e vulneráveis, forçados a confiar em profissionais que deverão proteger seus interesses com sua competência, respeito à sua autonomia, veracidade e manutenção da confidencialidade.

- Resiliência: capacidade de se recobrar facilmente ou de se adaptar para se manter composto, flexível e competente em meio ao caos clínico.

Esses profissionais - detentores das características listadas - deverão, entre outros aspectos, ser capazes de priorizar ações, como discutiremos a seguir.

Um dos temas que mais suscitam debates éticos relacionados com o cuidado em situações de urgência e emergência é a prioridade no atendimento. Que critérios devem ser utilizados para decidir sobre a prioridade do paciente A ou B, entendendo-se que a priorização em uma situação de emergência pode significar a escolha entre viver ou morrer, ou mesmo de sobreviver com sequelas muito significativas?

Não é uma discussão simples, e muito menos uma decisão fácil de tomar no calor dos acontecimentos. Como vimos no caso do dr. Arnaldo (Capítulo 2), podemos resumir a pergunta implícita como: considerando-se uma situação em que não intervir imediatamente em pacientes com pequenas possibilidades de recuperação pode significar o fim dessas possibilidades, seria mais correto atender prioritariamente o paciente cujo 
estado é mais grave - ainda que, com isso, aumente a possibilidade de que enfermos em estado menos grave e que teriam maior chance de se recuperar amplamente tenham o seu estado de saúde agravado - ou o paciente que apresenta maior possibilidade de recuperação? É claro que a indagação diz respeito às situações em que haja um desequilíbrio entre a capacidade de uma unidade e a demanda por cuidado. Se for possível atender a todos igualmente, então não haverá dilema.

Para a Associação Médica Mundial - cuja assembléia geral de outubro de 2006 reviu e aprovou a nova versão da antigamente chamada Declaração de Estocolmo, hoje Instrução sobre Ética Médica na Ocorrência de Desastres (World Medical Association. Statement on Medical Ethics in the Event of Disasters) -, as vítimas devem ser classificadas de acordo com a gravidade de seu quadro e com a possibilidade de serem salvas. A entidade preconiza que a prioridade deva ser dada a vítimas que possam ser salvas, cujas vidas estejam em perigo imediato e requeiram tratamento rápido ou dentro das próximas horas. Em seguida viriam as vítimas cujas vidas não estão em perigo imediato e necessitam de atendimento, mas não de cuidado médico urgente. As próximas seriam as pessoas feridas que necessitam apenas de tratamento secundário e possam ser tratadas depois ou por profissionais de auxílio, seguidas das vítimas psicologicamente traumatizadas que precisam ser atendidas, não precisam ser levadas individualmente a cuidados, mas podem necessitar de sedação se estiverem intensamente transtornadas.

A Associação Médica Mundial preconiza que as vítimas cuja condição exceda os recursos terapêuticos disponíveis, que 
sofram danos extremamente severos como irradiação ou queimaduras, de certa extensão e grau, mas não possam ser salvas nas circunstâncias específicas e possam ser consideradas como casos cirúrgicos complexos que requeiram uma operação particularmente delicada, o que levaria muito tempo e obrigaria o médico a fazer uma escolha entre elas e outros pacientes, sejam colocadas entre as últimas a receber atenção. Preconizam que essas vítimas sejam classificadas como casos de emergência "além de cuidados". A decisão de abandonar uma pessoa ferida "por causa de prioridades" ditadas pela situação de desastre não pode ser considerada como "fracasso em ajudar uma pessoa em perigo mortal". Isso seria justificado pela intenção de reduzir o número de vítimas.

Embora essa instrução mostre que para a Associação Médica Mundial a prioridade de atendimento deve ser dada àqueles que estão em estado mais grave mas ainda podem ser salvos, ela não resolve o dilema apresentado inicialmente. O documento reconhece uma condição como "além dos recursos terapêuticos disponíveis" e justifica, assim, uma escolha utilitarista. Isso deixa ainda mais claro quão complexa é a situação, com tantas variáveis a serem consideradas. É mister incluir, nesse conjunto, o fato de que todos os códigos de ética das profissões de saúde no Brasil estabelecem como dever dos profissionais o cuidado dos pacientes em situações de emergência, vedando que tal cuidado seja negado quando não houver outro profissional para assumir o caso, o que apenas confirma como os códigos são limitados na solução desse tipo de conflito. 
Conflitos entre os pontos de vista dos enfermos e dos profissionais da saúde

O papel cada vez maior do respeito à autonomia da pessoa na sociedade contemporânea tem concorrido para uma ampliação da complexidade do cuidado da saúde. Nesses termos, não é incomum a ocorrência de situações nas quais os pontos de vista dos enfermos e dos profissionais da saúde são conflitantes. Como exemplo, podemos comentar os casos de reconhecida necessidade de hemotransfusão em seguidores da religião Testemunhas de Jeová.

O impedimento à realização de transfusão sanguínea tem, para as Testemunhas de Jeová, sustentação em textos bíblicos, entre os quais ressaltam o livro do Gênesis (9:3-4) - "Todo animal movente que está vivo pode servir-vos de alimento. Como no caso da vegetação verde, deveras vos dou tudo. Somente a carne com sua alma - seu sangue - não deveis comer" - e o Levítico (17:10) - "Quanto a qualquer homem da casa de Israel ou algum residente forasteiro que reside no vosso meio, que comer qualquer espécie de sangue, eu certamente porei minha face contra a alma que comer o sangue, e deveras o deceparei dentre seu povo". A proibição de "comer qualquer espécie de sangue" é estendida aos procedimentos de hemotransfusão.

A Constituição brasileira de 1988 , em seu artigo $5^{\circ}$, garante a liberdade de crença religiosa, assegurando que as pessoas possam tomar decisões acerca de sua vida em concordância com a própria fé. Assim, é legítimo que as testemunhas de Jeová se abstenham de receber sangue e hemoderivados. Mas a questão pode se tornar bastante difícil, especialmente em duas situações: 
- Quando aquele que toma a decisão corre risco de morrer - caso não seja realizada a hemotransfusão -, estabelecendo-se um conflito entre a autonomia do enfermo e a beneficência da equipe de saúde, a qual entende que fazer o bem significa transfundir; nessa circunstância, ambas as decisões - transfundir ou não transfundir - são eticamente defensáveis, a depender do princípio que se evocar para fundamentar a ação.

- Quando aquele que toma a decisão não é considerado plenamente capaz - caso dos menores de idade -, para os quais, em princípio, a escolha é atribuição dos pais ou responsáveis; nesse âmbito, as perguntas a que se deve responder referem-se à capacidade moral da criança - ou adolescente - e ao seu desejo. O ECA, Estatuto da Criança e do Adolescente, assegura, em seu artigo 17, o direito à liberdade de culto, garantindo igualmente o respeito a esta manifestação; nesses termos, são igualmente defensáveis, do ponto de vista ético, as decisões de transfundir e a de não transfundir.

Diferentes estudos têm demonstrado que muitos profissionais da saúde buscam utilizar técnicas alternativas à hemotransfusão; mas, nos casos em que tal procedimento se torna imperioso para salvar a vida do enfermo, a decisão costuma ser pela realização da transfusão, com todos os ônus a ela relacionados. Caso seja essa a escolha, o enfermo deve ser comunicado, pois a omissão da informação é um grave equívoco, tanto do ponto de vista moral - ainda maior desrespeito à já desrespeitada autonomia do sujeito - quanto técnico - de fato, o antecedente de hemotransfusão é extremamente importante na história patológica pregressa de qualquer indivíduo. Por outro lado, não é incomum o relato de pacientes que pedem que seja feito tudo o que for necessário, mas não sejam informados do que foi realizado. Não 
faltam sequer aqueles que dizem que confiam que Deus iluminará o profissional para que este tome a decisão mais apropriada e preferem não saber o que foi feito. Nesses casos, a obrigação de informar pode se tornar também um equívoco grave, posto que contrariaria algo que tenha sido expressamente solicitado por um agente autônomo que não deseja se incompatibilizar com sua própria comunidade moral.

A despeito das polêmicas em torno do tema - de certo modo extensíveis a outras situações nas quais há dissonância entre profissionais e pacientes -, podemos extrair, como regra geral, que a tomada de decisão da equipe deve ser respaldada na legislação brasileira e nos códigos de ética das profissões envolvidas, mas, sobretudo, no diálogo franco e honesto com os envolvidos - enfermo, familiares, profissionais da saúde e outros -, no qual devem ser enfatizados os prós e os contras de cada decisão. Cabe destacar, também, que a aplicação literal do firmado nos dispositivos legais é uma prática que o direito brasileiro tem cada vez mais deixado para a sua história. É cada vez mais frequente, para além das faculdades de direito, encontrar membros do Judiciário analisando as situações inclusive em seus aspectos éticos e interpretando a legislação, e não simplesmente aplicando-a mecanicamente.

A experiência acadêmica tem mostrado que há, em geral, grande dificuldade em perceber os aspectos morais relacionados com o cuidado da saúde, especialmente na lida com casos concretos. A expectativa de decidir com uma suposta neutralidade moral da ciência é, como demonstrado, uma falácia. É necessário, sim, mais prática. Vivemos um tempo de grandes transformações no país; há oportunidade de investir fortemente na formação de 
profissionais da saúde mais sintonizados com o seu tempo e que se distanciem de práticas heterônomas, ou seja, realizadas pela observância de regras que são apresentadas ao sujeito sem a devida reflexão crítica que o leve a tomar tais regras como suas.

No próximo capítulo traremos a discussão para dois momentos especialmente ricos em controvérsias morais e que suscitam grandes polêmicas, especialmente pela relevância que o assunto ganha para pessoas religiosas: o início e o fim da vida. Considerando esses dois momentos, optamos pela reflexão acerca de duas questões especialmente polêmicas no país: o aborto e a eutanásia. 



\section{4 la Bió́tica, 0 Início e 0 Fim da Vida: O ABORTO E A EUTANÁSIA}

No capítulo anterior, apresentamos questões relativas à bioética clínica, tendo como foco a tomada de decisão. Entre os problemas debatidos nesse âmbito têm substantiva relevância, desde as origens da bioética, os aspectos atinentes ao início e ao fim da vida.

A tomada de decisão em relação ao princípio e ao termo da existência continua sendo 'polarizada' em torno de duas ideias principais: o princípio da sacralidade da vida (PSV) e o princípio do respeito à autonomia da pessoa (PRA). Em grande medida, as argumentações pró e contra nas questões acerca dos extremos da vida - referentes, por exemplo, ao aborto e à eutanásia - são redutíveis a um desses princípios.

No presente capítulo trilharemos o seguinte caminho: a apresentação dos princípios morais que norteiam o debate - PSV e PRA - e, ato contínuo, a discussão sobre as principais temáticas relacionados à bioética do início e do fim da vida: o aborto e a eutanásia, respectivamente.

\section{PRINCÍPIOS MORAIS}

Os princípios da sacralidade da vida e do respeito à autonomia são elementos essenciais às discussões morais acerca do fim da vida. O PSV pressupõe, em termos absolutos, que a vida consis- 
te em um bem - concessão da divindade ou manifestação de um finalismo intrínseco da natureza -, tendo, assim, um estatuto sagrado, por isso não é mensurável do ponto de vista de todos os 'cálculos' que possam, eventualmente, ser feitos sobre ela, não podendo ser interrompida, nem mesmo por expressa vontade de seu detentor (Siqueira-Batista \& Schramm, 2005). Outra leitura possível acerca da sacralidade ganha força na afirmação de que a vida é sempre digna de ser vivida, ou seja, estar vivo é sempre um bem, independentemente das condições em que a existência se apresente.

A sacralidade da vida é considerada uma das mais contundentes objeções ao aborto e à eutanásia, mormente nas éticas cristãs e na tradição hipocrática. Sem embargo, uma questão se impõe de pronto: se a vida é realmente um bem, quem seria mais competente para julgar essa 'beatitude’? Afirmar de maneira genérica que a vida é algo bom em si mesmo é extremamente perigoso, conforme se constata em muitas das críticas que ganharam corpo ao longo do século XX. Isso se torna claro nas discussões relativas à distanásia - morte lenta, com grande sofrimento - e à obstinação terapêutica (ver adiante, neste capítulo). De fato, a própria assertiva acerca da vida como um bem em si mesmo pode ser questionada - afinal, uma doença grave e incurável, matizada pela dor, pode tornar uma vida insuportável para o titular da existência.

Ademais, como assinalado na posição religiosa anterior, outra questão é o porquê de se considerar sagrada apenas a vida humana. Por que não tratar todas as formas de vida como sagradas? O bioeticista Peter Singer considera discriminatório esse posicionamento, denominando-o de especismo: a exemplo do racismo 
que é a discriminação por raça, o especismo seria a discriminação pela espécie animal. $\mathrm{Na}$ verdade, em termos cristãos, é possível sustentar a primazia da vida humana sobre as demais com base no excerto bíblico: humanos, "feitos à imagem e à semelhança de Deus”. Entretanto, para os não cristãos ou não religiosos, ou até mesmo para os panteístas (que consideram Deus e o universo como uma realidade integrada), esse argumento não se sustenta; se não se reconhece que a vida humana tem estatuto "à imagem e à semelhança de Deus", duas perspectivas podem ser adotadas: ou nenhuma vida é plenamente sagrada ou todas as vidas o são.

A acusação de especismo feita por Singer àqueles que defendem a primazia do humano sobre os demais animais não se aplica apenas aos que o fazem por razões religiosas, mas também àqueles que admitem a sacralidade da vida relacionada à solidariedade humana. Com essa compreensão, o sagrado perde o seu conteúdo religioso e passa a significar algo que não se deve infringir ou que não se pode deixar de cumprir.

O princípio do respeito à autonomia da pessoa (PRA) pressupõe que se considerem, definitivamente, as livres escolhas dos sujeitos quando se tratar de questões morais. Reconhece, de fato, que a moralidade implica o estabelecimento de relações entre sujeitos autônomos - ou, ao menos, que um dos implicados seja autônomo (por exemplo, nos debates sobre a eticidade das pesquisas com animais, o outro da relação é um ser que não pode ser considerado autônomo) -, tornando importante que se delimite o conceito de autonomia.

Como já visto no Capítulo 2, a autonomia traz a ideia de autogoverno e autodeterminação. Entre os gregos antigos, dizia 
respeito às formas de governo autárquicas, isto é, as cidadesestado (pólis), organizações sociopolíticas capazes de se autogovernar e de se autogerir. $\mathrm{Na}$ Idade Moderna, o conceito de autonomia passa a se aplicar ao indivíduo, alcançando uma formulação moral sistemática com a Fundamentação da Metafísica dos Costumes de Kant (1988). Nesses termos, podemos definir como autônomo o indivíduo que age livremente de acordo com um plano escolhido por ele mesmo, da mesma forma que um governo independente administra seu território e define suas políticas.

A argumentação pelo respeito à autonomia enfatiza o respeito à liberdade de escolha da pessoa, isto é, sua competência em decidir, autonomamente, aquilo que considera importante para viver sua vida, incluindo nessa vivência os processos de nascer e de morrer, de acordo com os seus valores e interesses legítimos. Desse modo, o PRA pressupõe que cada pessoa tem o direito de dispor de sua vida da maneira que melhor lhe aprouver.

Procuramos ser didáticos nesta apreciação sobre o PSV e o PRA, de modo a permitir a compreensão do núcleo dos argumentos relativos às questões bioéticas concernentes ao início e ao fim da vida. Entretanto, ambos dizem respeito a 'extremos morais', os quais podem se mostrar profundamente imbricados - e, por vezes, até indevidamente misturados e confundidos - no discurso dos envolvidos, conforme mostraremos a seguir.

\section{Bió́tica e 0 InÍCiO DA VIDA: 0 ABORTO}

O aborto é um dos temas mais polêmicos da atualidade e tem fomentado múltiplos debates, mormente nos âmbitos político, médico, jurídico e filosófico. Mas, se a questão é pujante nas 
sociedades ocidentais contemporâneas, tal situação não se caracteriza absolutamente como regra: o aborto foi aceito e praticado por membros de diferentes culturas desde a Antiguidade; passou a ser condenado bem mais recentemente, em 1869, pela Igreja católica (Muraro, 1989). Ademais, de modo geral, a história do repúdio ao aborto vincula-se, em grande parte, aos momentos de declínio da taxa de natalidade, como no período de derrocada do império romano e nos países da Europa Ocidental no início do século XX, após as grandes baixas populacionais sofridas durante a Primeira Guerra Mundial.

O espaço definitivo para a colocação do aborto em pauta, no hemisfério norte, consolidou-se a partir das transformações sociais ocorridas na década de 1960, as quais se relacionaram intimamente às lutas políticas das feministas em prol da liberdade sexual e reprodutiva e ao surgimento da 'pílula anticoncepcional', que tornou possível reduzir enormemente o risco de que um ato sexual se transformasse em uma ação reprodutiva. Por outro lado, nas sociedades latino-americanas, tal movimento ganhou força com um atraso de vinte anos, em decorrência do período autoritário e arbitrário que vigorou na maior parte de nossos países nas décadas de 60 e 70 do último século. Com a redemocratização, nossa população voltou a discutir sobre seus direitos individuais e sociais e a lutar por eles.

O fato de ser considerado um crime no Brasil não impede que o aborto seja amplamente utilizado para impedir a concretização da maternidade, como demonstrou o estudo do The Alan Guttmacher Institute (1994), que estimou a realização de 4.775.000 abortos na América Latina no ano de 1990, 4.620.000 dos quais em condições de ilegalidade (ou seja, em 96,8\% dos 
casos), e, no Brasil, de 1.443.350 abortos ilegais, à razão de 31 por cem gravidezes. Considerar o aborto apenas do ponto de vista legal é fechar os olhos para um problema que insiste em se colocar, diuturnamente, nos serviços de saúde e no âmbito mais amplo da sociedade brasileira. Até porque, como se sabe, as leis mudam com muito menos rapidez do que os costumes e práticas da sociedade. Identificando-se o tamanho do problema, reconhece-se implicitamente o quanto a atividade é praticada, apesar de todas as restrições legais e morais que as mulheres sofrem.

Uma das consequências desse primeiro ponto é a caracterização do 'aborto provocado' como um sério problema de saúde pública no país, na maioria das vezes realizado de forma velada e com resultados catastróficos. São também inúmeros os estudos que detectam o aborto clandestino como importante causa de mortalidade materna no Brasil (Fusco, Andreoni \& Silva, 2008; Diniz et al., 2009).

Nesse caso, uma vez mais, a desigualdade de acesso aos procedimentos médicos se manifesta: as maiores vítimas são as mulheres de baixa renda, as quais, por não poderem pagar um valor que supera em muitas vezes o do salário mínimo de nosso país, acabam recorrendo a práticas extremamente lesivas ao seu organismo - como a automedicação, com medicamentos frequentemente de qualidade e origem duvidosas, e a submissão a técnicas altamente perigosas empregadas por curiosos.

Apesar de haver, hoje, maior liberdade para se interrogar e discutir acerca dos aspectos (bio)éticos do aborto e do seu impacto social e sanitário, muito pouco se tem avançado efetivamente na caracterização mais clara do problema. Destacam-se, entre os fatores que têm contribuído para essa situação: 
- As múltiplas e díspares realidades e ordens discursivas albergadas pelo conceito, na medida em que uma série de motivações e contextos diferentes podem se tornar manifestos na decisão de interromper uma gravidez em curso.

- A dificuldade em manter um debate de alto nível e embasado em argumentação legítima - e não em espúrios 'enredamentos retóricos', os quais têm muito mais o intuito de confundir (com vistas, em última análise, à manipulação dos sujeitos) do que de esclarecer sobre os pontos que estão em jogo neste delicado assunto.

Com efeito, antes de apresentarmos as argumentações pró e contra, torna-se necessário delimitar os conceitos relativos ao aborto.

$\mathrm{O}$ aborto pode ser caracterizado, de modo geral, como a interrupção da gestação antes de ser possível ao concepto manterse vivo no ambiente extrauterino. Em geral, utiliza-se a palavra 'abortamento' para o processo (ou o ato) e 'aborto' para o produto; tal distinção não será aqui considerada, utilizaremos o termo 'aborto' também para expressar o ato.

Há diferentes modos de classificar o aborto. Entretanto, do ponto de vista da bioética, torna-se útil a delimitação proposta por Diniz e Almeida (1998):

1. 'Interrupção voluntária da gravidez', realizada em nome da autonomia reprodutiva da grávida, ou seja, por falta de desejo de levar a gestação a termo (quer esta seja fruto de um estupro ou de uma relação consensual) - como no caso dos pais que optam pela interrupção por impossibilidade de assumir o compromisso da maternidade/paternidade em um dado momento.

2. 'Interrupção terapêutica da gravidez', praticada com o intuito último de salvar a mãe gravemente enferma, para quem a 
continuação do ciclo gravídico acabará desencadeando a morte - como no caso da gestante com diagnóstico de eclampsia.

3. 'Interrupção eugênica da gravidez', executada com base em princípios da eugenia, tais como valores racistas, sexistas, étnicos - o principal exemplo foram as práticas realizadas no Estado nazista, muitas das quais em conformidade com a lei, de aborto imposto às mulheres por questões puramente étnicas.

4. 'Interrupção seletiva da gravidez', motivada pela existência de graves lesões fetais, muitas das quais incompatíveis com a vida - o exemplo mais conhecido é a anencefalia.

É igualmente importante distinguir o aborto segundo a sua gênese, ou seja, se foi espontâneo - quando ocorre por causas da ordem biológica (muitas vezes genéticas ou placentárias) ou provocado, quando oriundo da ação humana, independentemente de sua motivação.

O Código Penal brasileiro foi promulgado em 1940, o que torna evidente, sem a necessidade sequer de uma análise prévia, o seu descompasso com a moral da sociedade brasileira do século XXI. Esse código penal considera o aborto um crime contra a vida (uma subclasse dos delitos contra a pessoa). Entretanto, seu artigo 128 determina que não seja punido o aborto praticado por médico em algumas circunstâncias específicas: I - se não houver outra forma de salvar a vida da gestante; II - se a gravidez for o resultado de estupro e o aborto for precedido por consentimento da gestante ou, quando incapaz, de seu representante legal.

Desse ponto de vista, em qualquer situação que não se enquadre na impossibilidade de "salvar a vida da gestante" de outra maneira e na gravidez que "resulta de estupro", o aborto é con- 
siderado ato criminoso, passível de punição. A não punição está, assim vinculada ao eventual reconhecimento da falta de culpa da mulher, ou seja, ao fato de a gravidez não ter sido resultado de um comportamento 'devasso', o que demonstra o espírito com que a lei foi escrita. Como dissemos, o fato de o Código Penal ser praticamente septuagenário e de boa parte dos debates sobre aborto ter ocorrido na segunda metade do século XX tem suscitado a proposição de modificações na legislação vigente. Duas situações atuais exemplificam tal afirmativa:

O recente embate jurídico em torno do aborto no caso de o feto ser anencéfalo, desencadeado por uma liminar concedida pelo ministro Marco Aurélio de Mello à Confederação Nacional dos Trabalhadores em Saúde em julho de 2004, a qual garantia a sua realização sem a necessidade de aguardar a decisão judicial; a liminar foi cassada por sete votos a quatro em outubro de 2004, ainda que não tenha sido julgado seu mérito.

A recusa, em maio de 2008, pela Comissão de Seguridade Social e Família da Câmara dos Deputados, de um projeto de lei pela descriminalização do aborto (que tramitava há 17 anos na Câmara); o projeto ainda se encontra em análise pela Comissão de Constituição e Justiça e de Cidadania.

A atual polêmica legal em torno do aborto é, em suma, um reflexo de discussões de mesmo teor levadas a cabo na sociedade, as quais se estruturam, muitas vezes, em torno de argumentos éticos e, com frequência ainda maior, em torno de questões religiosas e de gênero.

O debate bioético acerca do aborto situa-se entre dois extremos morais: aqueles baseados no PSV, argumentos contra, aqueles sustentados no PRA, argumentos pró. Para um panorama geral 
sintético, que ofereça uma rápida identificação dos atores sociais envolvidos no debate e suas posições, podemos afirmar que a defesa do PSV, feita, por exemplo, pelo movimento Brasil Sem Aborto, assume a ideia de que a vida é sagrada e, consequentemente, o aborto nunca é bioeticamente defensável. A defesa do PRA, feita pelo movimento feminista em geral - por exemplo, a Rede Feminista -, preconiza que a mulher é livre para decisões sobre a própria vida, incluindo sua sexualidade e reprodução. Desse ponto de vista decorre a compreensão de que aborto é sempre bioeticamente defensável, exceto quando é realizado contra a vontade da mulher. Entre uma e outra posição estão as mulheres do movimento Católicas pelo Direito de Decidir, que reafirmam sua condição de seguidoras de uma doutrina religiosa mas não aceitam certas proibições morais, que entendem não ter fundamento religioso. Para esse movimento o aborto pode ser bioeticamente defensável.

Esse panorama é uma simplificação extrema das discussões morais sobre o aborto. $\mathrm{Na}$ verdade, a maior parte das pessoas assume posições concordes com a 'região de incerteza', na qual as sínteses - muitas vezes racionalmente incoerentes - entre o PSV e o PRA permitem a adoção de pontos de vista nos quais a conciliação entre os extremos é possível.

O núcleo da argumentação contrária ao aborto é o reconhecimento de que a vida é indisponível, em qualquer circunstância, por ser um bem sagrado (PSV). Essa posição é reiteradamente adotada pelos adeptos das éticas religiosas - especialmente, no Brasil, das éticas cristãs -, como expresso na Declaração Quaestio de Abortu, sobre o aborto provocado (Vaticano, 1974), segundo 
o qual a vida humana é o valor primordial que é preciso proteger e promover.

Com efeito, de acordo com o PSV, a vida humana é indisponível, ou seja, nessas situações limite não há espaço para a autonomia, de modo que se tem, de fato, um discurso baseado na heteronomia (Diniz \& Almeida, 1998). Nessa perspectiva, o PSV se desdobra na concepção de que o embrião/feto é, desde a fecundação, uma pessoa em ato ou em potência. Essa posição encerra problemas relacionados à complexidade da ideia de pessoa - conceito muito mais antropológico do que jurídico - e às dificuldades para a delimitação do que é humano - qual é o conceito de homem que subjaz à consideração de algo 'humano'? -, sendo frequente e consistentemente desconstruída pelos autores que defendem o aborto.

O núcleo da argumentação favorável ao reconhecimento do direito ao aborto é a perspectiva do respeito à autonomia reprodutiva (da mulher). Nesse domínio, é paradigmática a analogia elaborada por Judith J. Thomson no artigo "A defense of abortion", de 1971.

Imagine que um dia você acorda, ao amanhecer, e descobre que está em um leito hospitalar, ligado, de algum modo, a um indivíduo que se encontra inconsciente em uma cama ao lado da sua. Você recebe, então, a comunicação de que esse indivíduo é um famoso músico - violinista - com uma enfermidade renal. Ele sobreviverá somente se o seu sistema circulatório for ligado ao de outra pessoa que tenha o mesmo tipo sanguíneo e, no momento, apenas você preenche esses requisitos. Em decorrência disso, você foi sequestrada - por uma sociedade de amantes da música - e, ato contínuo, procedeu-se à ligação. Caso você 
deseje desligá-lo - o que é possível, por se tratar de um hospital bem conceituado -, ele evoluirá inexoravelmente para óbito; ao contrário, se optar por mantê-lo ligado, ao final de (apenas) nove meses, o músico irá se recuperar e você poderá, então, se desligar dele, sem maior risco.

Nesse exemplo, a despeito de o músico ser inocente em relação à conexão dos sistemas circulatórios - assim como seria o embrião - e de ter direito à vida, não há uma estrita obrigação moral em se manter ligado a ele. De fato, por uma motivação qualquer, a decisão por manter a ligação poderia ser tomada, mas, também, por qualquer outra consideração, o violinista poderia ser desligado, sem que este ato seja necessariamente considerado imoral ou criminoso. Com efeito, ainda que o músico/embrião tenha direito à vida, isto "não dá o direito ao uso do corpo de terceiros, mesmo que, sem esse uso, alguém venha a morrer" (Singer, 2002: 194).

A analogia de Thomson é particularmente aplicada à defesa do aborto nos casos de estupro, uma vez que, como o sequestro, o estupro é um ato inequivocamente violento. Mas talvez o argumento de Thomson possa se aplicar a casos em que o acaso ou o desconhecimento, e não uma violência, tenha levado alguém a estar ligado ao violinista. Assim, Peter Singer (2002: 195) propõe: "suponha que você se viu ligado ao violinista, não por ter sido sequestrado pelos amantes da música, mas porque, em visita a um amigo doente, ao tomar o elevador do hospital você, inadvertidamente, apertou o botão errado e foi parar em um setor normalmente visitado apenas por voluntários candidatos a ficarem ligados a pacientes que só assim poderiam sobreviver". Imagine, então, que uma equipe médica que aguardava o próximo 
voluntário confunde você com ele, aplica-lhe uma anestesia e faz a ligação. Nesse caso, Singer questiona se não se pode também usar o mesmo argumento, uma vez que o descuido ou ignorância ou a violência se equivalem em seu caráter involuntário.

A questão, em um ou outro contexto, é a mesma: no final das contas, a decisão, autônoma, deve ser da mulher.

A argumentação aqui apresentada presta-se à defesa da 'bioeticidade' do aborto, núcleo do debate nesta seção. Entretanto, em muitas circunstâncias, as correntes pró-aborto têm um discurso dirigido mais à descriminalização do que à eticidade do procedimento em si. De fato, viver em uma sociedade na qual se pode exercer a liberdade para escolher levar - ou não - uma gravidez a termo é um aspecto essencialmente inscrito no debate atual sobre o respeito à autonomia.

Não se pode esquecer, pela relevância, a perspectiva de gênero na qual está inserida a discussão. Em um mundo marcadamente masculino, a negação do direito ao aborto às mulheres serve também como um instrumento de controle de sua sexualidade. Como disse certa vez Florynce Kennedy, advogada e ativista estadunidense, "se os homens pudessem engravidar, o aborto seria um sacramento".

A questão do aborto talvez seja o campo da bioética no qual as disputas argumentativas são mais acirradas. Esse aspecto - e a constatação de que milhares de mulheres sofrem e morrem, todos os anos, vítimas dos procedimentos utilizados em abortos clandestinos - torna ainda mais imperiosa a discussão, honesta e racional, acerca da sua 'bioeticidade' e dos seus aspectos legais. Sem desconsiderar, todavia, que o debate se dá em um contexto essencialmente dominado por uma visão masculina, segundo a 
qual o controle da sexualidade feminina está intimamente ligado às ações contrárias a qualquer medida de interrupção da gravidez e ao uso de métodos seguros de contracepção, como são as ações protagonizadas pela Igreja católica.

\section{Bió́tica e 0 Fim dA VidA: A EUtAnÁsia}

A eutanásia é, entre todos os temas relativos à bioética do fim da vida, aquele que mais provoca polêmica. De fato, desde o final do século passado, uma série de eventos tem tornado mais evidente a premência de se discutir a questão, cabendo comentar:

- O progressivo envelhecimento populacional - como observado no Brasil - permite que um maior contingente de pessoas alcance a senectude, tornando-se mais suscetível às moléstias crônicas e degenerativas e, por conseguinte, a um processo de morrer mais 'prolongado' e sujeito a padecimento.

- A aprovação de leis autorizando a eutanásia em vários países do mundo, como a Austrália (de julho de 1996 a março de 1997), a Holanda (abril de 2001), a Suíça e a Bélgica (maio de 2002).

- As indagações relacionadas aos avanços das técnicas de manutenção da vida e prolongamento da sobrevida.

- A ocorrência de várias 'situações clínicas' que levantaram incontornáveis questões sobre a moralidade da eutanásia e do suicídio assistido - casos Karen Ann Quinlan (em 1975-1976, que voltará a ser comentado no Capítulo 5); Diane-Quill (em 1996, uma senhora de 45 anos recebeu o diagnóstico de leucemia e não aceitou ser tratada. Seu médico, dr. Quill, aceitou sua decisão e ajudou-a no seu suicídio); Robert Dent (em 1996 foi a primeira pessoa no mundo a receber a eutanásia com 
autorização judicial); Ramón San Pedro (morto em 1998, teve seu caso de suicídio assistido relatado no filme Mar Adentro); Jack Kevorkian, o "doutor Morte" (médico que nos anos 90 ofereceu, até ser preso, um programa de suicídio assistido); Vincent Humbert (em 2003, esse jovem bombeiro morreu em uma ação de eutanásia ativa) -, somente para mencionar as mais notórias.

Entretanto, ainda que a eutanásia venha merecendo grande atenção da comunidade mundial, o debate está muito longe do desejável na sociedade brasileira. Pelo fato de ser ainda considerada crime no Brasil - como disposto no artigo 121 do Código Penal -, ainda se observa um pacto de silêncio nas unidades de cuidado da saúde, nas quais a decisão por interromper, ou não, a terapêutica acaba por ser tomada às escuras, por profissionais habitualmente sem qualquer preparação para isso e, pior, muitas vezes à revelia dos familiares e do próprio enfermo.

Nesses termos, um dos complicadores - no Brasil e em outros países - é a constatação de que a o termo 'eutanásia' encerra significativa polissemia, o que tem provocado grandes dificuldades nos aspectos relativos ao debate moral sobre o assunto. Com base nessas considerações, apresentaremos o(s) conceito(s) e as classificações da eutanásia e, em seguida, as argumentações contra e pró.

O termo 'eutanásia' foi utilizado, pela primeira vez, pelo historiador romano Suetônio, no século II d.C., para descrever a morte tranquila do imperador Augusto. Essa compreensão da eutanásia como boa morte reaparece na definição de Émile Littré (1908), autor que a define como "boa morte, morte suave e sem sofrimento”. Em termos mais contemporâneos, é entendida 
como a antecipação voluntária do passamento, imbuída de uma finalidade humanitária - sobretudo para a pessoa, mas também para a coletividade à qual pertence o moribundo -, dirigida à suspensão de um sofrimento insuportável. A eutanásia seria, assim, melhor entendida como a abreviação do processo de morrer de um enfermo, por ação ou não ação, com o objetivo último de aliviar um grande e insuportável sofrimento.

Em relação à classificação, atualmente priorizam-se as distinções em termos do ato em si e do consentimento do enfermo. Essas distinções foram sistematizadas por Siqueira-Batista \& Schramm (2005), conforme se segue.

Distinção quanto ao ato:

- Eutanásia ativa - ato deliberado de provocar a morte sem sofrimento do paciente, por fins humanitários (por exemplo, utilizando uma injeção letal).

- Eutanásia passiva - quando a morte ocorre por omissão proposital em se iniciar uma ação médica que garantiria a perpetuação da sobrevida (por exemplo, deixar de iniciar aminas vasoativas no caso de choque não responsivo à reposição volêmica).

- Eutanásia de duplo efeito - nos casos em que a morte é acelerada como consequência de ações médicas não visando ao êxito letal, mas sim ao alívio do sofrimento de um paciente (por exemplo, emprego de morfina para controle da dor, gerando, secundariamente, depressão respiratória e óbito).

Distinção quanto ao consentimento do enfermo:

- Eutanásia voluntária - em resposta à vontade expressa do doente, o que seria um sinônimo de suicídio assistido. 
- Eutanásia involuntária - quando o ato é realizado contra a vontade do enfermo, o que, em linhas gerais, pode ser igualado a homicídio; todavia, a concepção de Helga Kuhse (Kuhse \& Singer, 1998) é algo distinta: a autora caracteriza a eutanásia involuntária como aquela que se pratica em uma pessoa que havia sido capaz de outorgar ou não o consentimento à sua própria morte, mas não o fez, seja por não ter sido solicitada, seja por ter rechaçado a solicitação devido ao desejo de seguir vivendo.

- Eutanásia não voluntária - quando a vida é abreviada sem que se conheça a vontade do paciente.

Do ponto de vista da bioética, podem ser construídos argumentos distintos para as diferentes categorias de eutanásia relativas ao ato em si, havendo aqueles que condenam peremptoriamente a eutanásia ativa, mas "aceitam” a eutanásia passiva - por exemplo, julgando legítimo que um enfermo se negue a passar por medidas terapêuticas extraordinárias, ou seja, recuse a distanásia - ou que, em decorrência de uma determinada modalidade terapêutica, acabe por sobrevir o óbito - no caso, eutanásia de duplo efeito. Todavia, no que se refere ao consentimento do enfermo, há justificativa moral para a eutanásia voluntária e, eventualmente, para a não voluntária, mas não para a involuntária. Abordaremos os argumentos contra e pró a eutanásia a seguir, mas antes apresentaremos, sinteticamente, o que está previsto em alguns dispositivos legais.

De modo análogo ao previsto para o aborto, o Código Penal brasileiro penaliza a eutanásia por entendê-la como homicídio (crime contra a vida); de acordo com o seu artigo 121, é crime matar alguém. Entretanto, seu primeiro parágrafo determina que 
se o agente cometer o crime impelido por motivo de relevante valor social ou moral, ou sob o domínio de violenta emoção, logo em seguida a injusta provocação da vítima, o juiz pode reduzir a pena de um sexto a um terço.

Encontra-se em tramitação no Senado Federal o Projeto de Lei 125/96, de 1995, estabelecendo critérios para a legalização da "morte sem dor". Nesse caso, pessoas com sofrimento físico ou psíquico poderiam solicitar a realização de procedimentos que visem à própria morte, desde que autorizados por uma junta médica e que haja expressa anuência do enfermo (ou de seu familiar, caso este esteja impossibilitado).

No final do século passado, foi criada uma comissão de juristas para elaborar uma proposta de revisão do Código Penal brasileiro. Essa comissão preparou um anteprojeto que não chegou a ser submetido à apreciação legislativa, mas foi discutido em alguns fóruns. No Rio de Janeiro, por exemplo, ocorreu um debate sobre a proposta de eutanásia prevista no anteprojeto, indicando que existe a percepção da sociedade de que uma nova regulamentação sobre a eutanásia é apenas uma questão de tempo. O próprio Conselho Federal de Medicina já elaborou uma resolução sobre a terminalidade da vida (ver adiante), o que também indica a mesma necessidade de se regulamentar o que, de fato, já ocorre.

O mais importante argumento contra a eutanásia diz respeito ao PSV. Nesses termos, considera-se que a vida é sempre digna de ser vivida - independentemente dos sofrimentos aos quais se esteja submetido - e imoral lançar mão de medidas para abreviar o processo de morrer. Na verdade, para o cristianismo o sofrimento é visto como algo aceitável, e até mesmo benéfico, como 
registrado na "Declaração sobre a eutanásia" (Vaticano, 1980). Nessa declaração, o Vaticano afirma que a dor, sobretudo nos últimos momentos da vida, assume um significado particular no plano salvífico de Deus, sugerindo que o sofrimento poderia ter um aspecto redentor.

Nessa perspectiva, a sacralidade da vida humana e a disposição para o sofrimento tornam muito difícil o desenvolvimento de ponderações em prol da eutanásia. Ainda assim, as dificuldades aqui identificadas em relação ao PSV tornam mais difícil a sua aceitação, para aqueles que não comungam da fé - religiosa ou não - de que a vida, humana, tem um estatuto sagrado.

Outra consideração bastante encontrada na literatura bioética sobre a eutanásia é o argumento de slippery slope - traduzível, em português, como ladeira escorregadia -, com base no qual se pretende justificar que não devem ser feitas "concessões", aparentemente inócuas, em temas controversos, sob pena de se abrir o precedente para atitudes de inequívoco malefício. Nesses termos, oposições alicerçadas no argumento 'escorregadio' incluiriam: a potencial desconfiança - e subsequente desgaste - na relação médico-paciente; a possibilidade de atos não inspirados em fins altruístas, mas motivados por outras razões (por exemplo, questões de heranças, pensões, seguros de vida e outras); a ocorrência de pressão psíquica - por exemplo, o pensamento, pelo enfermo, de que a sua condição é um verdadeiro 'estorvo' para os familiares -, a qual poderia deixar os pacientes, cuja morte se aproxima, sem perspectiva outra que não a 'eutanásia', de fato não desejada e, portanto, de alguma forma imposta por razões circunstanciais; e a erosão definitiva do respeito à vida humana, tomando-se como base o recorrente exemplo do na- 
zismo. Entretanto, nem sempre tal preocupação poderá ser fundamentada, pois o mau uso (ou o abuso) de algo não contraindica, em termos absolutos, o seu uso. Para identificar quais dessas argumentações baseadas na 'ladeira escorregadia' são falácias, basta que demonstremos que a consequência anunciada não é necessária, pode não acontecer.

O PRA, à semelhança do anteriormente descrito nas questões bioéticas acerca do aborto, é o núcleo comum para a defesa da bioeticidade da eutanásia. Nesses termos, se um sujeito autônomo é capaz de tomar inúmeras decisões ao longo da própria existência, torna-se plenamente justificável que ele tenha, igualmente, a possibilidade de decidir sobre o fim de sua vida - especialmente em situações de extremo sofrimento -, quer para mantê-la, quer para extingui-la, quem sabe em prol de uma boa morte, 'eu-tanásia'. No bojo desse debate, a autonomia pressupõe que cada indivíduo tem o direito de dispor de sua vida da maneira que melhor lhe aprouver, optando pela morte no exaurir de suas forças, ou seja, quando sua própria existência se tornar subjetivamente insuportável.

As limitações da autonomia são as mesmas anteriormente comentadas, as quais concorrem para reduzir as possibilidades de aplicação irrestrita deste princípio.

Outros dois elementos são importantes para a argumentação a favor da eutanásia:

1. O princípio da qualidade da vida (PQV), princípio prima facie-ou seja, aplicável somente em determinadas circunstâncias, destituído, portanto, de um valor universal e inatacável -, que afirma também a existência de um valor para a vida, mas aplicável tão-somente se esta for provida de um certo número e grau 
de qualidades, histórica e socioculturalmente construídas, e aceitas pelo titular de uma vida particular (Schramm, 1995). A contraposição ao PSV tem a ver com a possibilidade de atos absurdos, geradores de sofrimentos insuportáveis, apenas para sustentar uma (sobre)vida que pode ser mais um castigo do que uma dádiva.

Uma das questões mais íntimas relacionadas à qualidade de vida está em determinar qual o real significado de uma vida que vale a pena ser vivida, e a quem deve ser dada a prerrogativa de decidir sobre tal significação. $\mathrm{Na}$ esteira da herança do filósofo Immanuel Kant - segundo a qual um ato genuinamente moral deve ser concebido no pleno exercício da liberdade do sujeito ético -, cabe sempre admitir que o principal interessado em viver deve ter a prioridade em decidir sobre sua vida e sua morte. Isso remete, quase que instantaneamente, à questão da autonomia pessoal, considerada o mais importante princípio para legitimar a eutanásia, pelo menos se pensada no contexto das sociedades complexas liberais e democráticas contemporâneas. A qualidade de vida, assim, remete ao PRA.

2. O conceito de compaixão laica (Siqueira-Batista \& Schramm, 2008), entendido não como julgamento do outro - mas tão-somente sua aceitação, o amparo à sua condição de vivente - tem sido identificado como mais um elemento capaz de sustentar a bioeticidade da eutanásia. Assim, ao se reconhecer que a eutanásia pressupõe, de modo inequívoco, a perspectiva de amainar o sofrimento, torna-se significativo adotar uma atitude, em relação ao enfermo inserido no processo de morrer, de respeito a esse seu momento, dispondo-se a atender seu desejo de morrer, sem julgá-lo e sem tomar arbitrariamente decisões tão importantes em seu lugar. 
Levando-se em conta todos os aspectos indicados, torna-se premente ampliar as discussões - acadêmicas e sociais - em torno da eutanásia, procurando equacionar as tensões entre PSV e PRA - igualmente relevantes na bioética do aborto - em um discurso que se institui no bojo de uma sociedade (que se pretende) laica, plural e democrática. Desse ponto de vista, é possível que a compaixão laica - compreendida em suas relações com a ética do cuidado e com a bioética da proteção (SiqueiraBatista \& Schramm, 2009) - permita uma fecunda articulação entre os princípios e argumentos morais acerca do fim da vida, a qual contemple os princípios de sacralidade da vida, qualidade de vida, autonomia, e supere o argumento da ladeira escorregadia. De fato, a vida de um ser humano submetido a excruciante padecimento não deixa de ser sagrada, um valor maior a ser respeitado - colocando-se de lado os dogmatismos cegos e os fundamentalismos - pela decisão autônoma, por parte daquele que sofre, de pôr um fim ao seu curso. Nesse caso, a própria admissão, em meio a um padecimento incurável - e intratável - de que já não vale a pena prosseguir demonstra, em certo sentido, que o doente atribui alto valor à sua própria vida, não desejando profaná-la ao permitir que ela se esvaia em dias e noites de martírios sem fim. Morrer, nesse caso, pode significar também uma clara demonstração de apreço pela própria existência, situando-a em uma dimensão sagrada. E se esse mesmo homem é amparado e - por que não? - protegido, no sentido de tornar fato sua inquebrantável disposição para o ocaso, não se corre o risco de estender, escorregar, indevidamente para situações obscuras e danosas em relação à prática da eutanásia, pois a palavra daquele que sofre, o titular da vida, será sempre a última fronteira. 
O debate bioético sobre o fim da vida, no Brasil, se ampliou, recentemente, com a proposição do conceito de ortotanásia, a "morte no tempo certo". Para os que defendem a adoção deste termo, ortotanásia deve ser compreendida como uma atitude entre a eutanásia e a distanásia, que asseguraria uma morte digna, sem abreviações e sem sofrimentos adicionais, por vezes associada à oferta de cuidados paliativos. A Resolução n. 1.805/2006 do Conselho Federal de Medicina (Brasil, 2006, ver texto completo abaixo), por sua vez, regulamentava a limitação ou suspensão de procedimentos e tratamentos que sustentassem a vida do doente, mas garantindo-lhes os cuidados necessários para aliviar os sintomas que levassem ao sofrimento. Lamentavelmente, essa resolução está com seus efeitos suspensos por decisão liminar do juiz dr. Roberto Luis Luchi Demo, nos autos da Ação Civil Pública n. 2007.34.00.014809-3, da 14ª Vara Federal, movida pelo Ministério Público Federal.

Resolução CFM n. 1.805/06, sobre a terminalidade da vida

Art. $1^{\circ}$ - É permitido ao médico limitar ou suspender procedimentos e tratamentos que prolonguem a vida do doente em fase terminal, de enfermidade grave e incurável, respeitada a vontade da pessoa ou de seu representante legal.

$\int 1^{\circ} \mathrm{O}$ médico tem a obrigação de esclarecer ao doente ou a seu representante legal as modalidades terapêuticas adequadas para cada situação.

$\int 2^{\circ} \mathrm{A}$ decisão referida no caput deve ser fundamentada e registrada no prontuário.

$\int 3^{\circ}$ É assegurado ao doente ou a seu representante legal o direito de solicitar uma segunda opinião médica. 
Art. $2^{\circ}$ - O doente continuará a receber todos os cuidados necessários para aliviar os sintomas que levam ao sofrimento, assegurada a assistência integral, o conforto físico, psíquico, social e espiritual, inclusive assegurando-lhe o direito da alta hospitalar.

Art. $3^{\circ}$ - Esta resolução entra em vigor na data de sua publicação, revogando-se as disposições em contrário. (Brasil, 2006)

Podemos considerar, por fim, que nascer e morrer são pontos extremos na existência humana, reconhecendo, no âmbito da cultura, um grandioso esforço para atribuir-lhes sentido, seja por meio da religião, da filosofia, da ciência ou de outras manifestações do espírito. Essas tentativas incluem ações capazes de trazer significativos problemas éticos - como o aborto e a eutanásia -, os quais deverão ser apreciados pelo profissional da saúde, sujeito que habitualmente precisará tomar (as melhores) decisões sobre a vida e a morte de outrem. No próximo capítulo apresentaremos os diferentes tipos de colegiados usualmente constituídos para o exercício da discussão ética, tratando de suas especificidades e das características que os distinguem entre si. 


\section{5| Comitês e Comissões Hospitalares: DE ÉtICA E dE BIOÉTICA}

A primeira questão que surge quando se fala dos comitês/ comissões hospitalares diz respeito à aparente superposição de organizações: de fato, há comissões/comitês de ética médica, de bioética e os de ética em pesquisa. Ademais, em alguns lugares são chamados de comitês e em outros, de comissões.

A criação de comitês hospitalares não é uma novidade na prática médica. Diferentes comitês e comissões hospitalares foram e são instituídos no Brasil e no mundo. Existem, por exemplo, comissões de controle de infecção hospitalar (CCIHs) e comitês de revisão de óbitos. São organizações com funções bem definidas e que as desempenham em benefício de atuais e futuros pacientes, buscando orientar profissionais da saúde e gestores sobre medidas e condutas a serem adotadas para o melhor desempenho das funções precípuas das unidades de saúde. Assim também são os comitês de ética e de bioética, os quais discutiremos separadamente, de forma a distingui-los claramente. O que essas comissões trazem como novidade socialmente relevante é a institucionalização da ética na área da saúde, de forma a permitir a análise de decisões a serem tomadas, e não apenas o exame de fatos passados.

Algumas questões importantes se colocam no horizonte desta discussão: esses comitês e comissões realizam as mesmas funções, só que com diferentes nomes? Ou têm especificidades? 
Neste capítulo, apresentaremos as particularidades de cada uma dessas organizações institucionais - enfocando as comissões de ética hospitalar, os comitês de ética em pesquisa e as comissões de bioética hospitalar - e a regulamentação que as disciplina.

\section{COMissões de ÉTICA hOSPITALAR}

Este tipo de comissão de ética caracteriza-se pela participação restrita aos membros de uma corporação específica, ou seja, não é multidisciplinar. Apresentaremos brevemente, a título de exemplo, as comissões da medicina e da enfermagem.

As comissões de ética médica hospitalar (CEM) começaram a ser criadas há cerca de vinte anos, e hoje estão regulamentadas pela Resolução CFM n. 1.657, de 2002, que estabelece normas de organização, funcionamento, eleição e competências das comissões de ética médica dos estabelecimentos de saúde. Essa referência, por si só, já delimita o âmbito de sua competência: o exercício profissional da medicina. As CEMs podem ser compreendidas como um 'braço' do Conselho Regional de Medicina no interior dos estabelecimentos de saúde. Sua missão corresponde à dos conselhos regionais. Entretanto, o Conselho Federal de Medicina, em sua página na Internet, ao defender a ideia de que a ação dos conselhos já extrapolaria "a aplicação do Código de Ética Médica e a normatização da prática profissional”, concluiu que, "ao defender os interesses corporativos dos médicos, o CFM empenha-se em defender a boa prática médica, o exercício profissional ético e uma boa formação técnica e humanista". Com o tipo de ação enunciada sobre esses pontos, mantém a oferta de serviços médicos de qualidade para a população, que seria a melhor forma de proteger os interesses da profissão 
médica e dos médicos. Assim, mesmo que, naturalmente, os organismos representativos da categoria atuem na construção e no debate da política de saúde, sua função precípua ainda continua sendo regulamentar e fiscalizar o exercício profissional - no caso, dos médicos. É nesse sentido que as CEMs atuam principalmente, como prevê o artigo $1^{\circ}$ da Resolução 1.657/2002 - que as regulamenta -, desempenhando "funções sindicantes, educativas e fiscalizadoras do desempenho ético da medicina em sua área de abrangência".

Assim como a sua congênere médica, as comissões de ética em enfermagem têm uma regulamentação originária de seu conselho federal - a Resolução 172/1994. Destinam-se, igualmente, a atuar como um braço dos conselhos regionais, zelando pelo exercício ético dos profissionais de enfermagem da instituição, ainda que pautando sua fiscalização na adequação das condutas ao Código de Ética dos Profissionais de Enfermagem, que se comprometem a divulgar. As comissões de enfermagem também são obrigadas a notificar o Conselho Regional de Enfermagem de sua jurisdição sobre irregularidades, reivindicações, sugestões e infrações éticas.

\section{COMitês de Ética em PESQuisa}

A Resolução 196/1996 do Conselho Nacional de Saúde (CNS) difundiu no Brasil uma categoria de comissão de ética, os comitês de ética em pesquisa (CEPs), os quais deveriam ser criados nas instituições que realizem pesquisas com seres humanos. A criação desse tipo de comissão foi sugerida pela Declaração de Helsinque, da Associação Médica Mundial, em sua revisão de 1975. Nessa declaração, determina-se que os projetos 
de pesquisa envolvendo seres humanos sejam necessária e previamente apreciados e aprovados por uma comissão independente, especialmente nomeada.

Esses comitês têm uma finalidade bastante específica e totalmente diferente daquela dos comitês de ética médica e de enfermagem, pois foram criados para "defender os interesses dos sujeitos da pesquisa em sua integridade e dignidade e para contribuir no desenvolvimento da pesquisa dentro de padrões éticos" (Brasil, 1996). Assim, qualquer projeto de pesquisa que envolva seres humanos, mesmo quando o pesquisador é um médico ou um enfermeiro, deverá ser avaliado por um CEP. O cumprimento dessa missão não se dá em prejuízo dos interesses últimos dos pesquisadores, pois parece óbvio que não há pesquisador de bom senso que não leve em consideração os melhores interesses dos sujeitos de sua pesquisa. Dessa forma, é razoável o entendimento de que os melhores anseios dos pesquisadores também são atendidos na avaliação dos seus protocolos de pesquisa.

Os CEPs, de acordo com a Resolução do CNS 196/1996, devem ser constituídos em instituições nas quais se realizam pesquisas envolvendo seres humanos, obedecendo às normas emanadas do Brasil. Esse colegiado não pode, por exemplo, ter em sua composição mais do que a metade de seus membros de uma única categoria profissional. Deve incluir profissionais com formações diversas, como os da área das ciências humanas e sociais, e necessariamente pelo menos um representante dos usuários da instituição. A representação dos usuários não deve se limitar a uma participação formal; seus delegados também devem avaliar projetos e emitir pareceres. E quem seriam os 
“usuários" aos quais faz referência a Resolução 196/96? O CNS estabeleceu, em sua Resolução 240/1997, alguns critérios para caracterizá-los: devem ser pessoas capazes de expressar pontos de vista e interesses de indivíduos e/ou grupos de sujeitos de pesquisas de determinada instituição, e representativos de interesses coletivos e públicos diversos. Tem sido discutida, nos últimos anos, a conveniência de se vincular, de forma mais específica, a representação dos usuários nos CEPs aos conselhos de saúde, estaduais e/ou municipais, visto que um representante de usuário em um hospital pode não ter força política e independência para confrontar interesses vinculados à indústria farmacêutica - ou correlatos -, por exemplo.

A independência dos CEPs na tomada de decisões é bastante importante e deve ser perseguida sempre. Os interesses de todos os atores envolvidos na pesquisa devem ser levados em consideração, mas a proteção que se deve aos sujeitos da pesquisa não pode ser solapada em benefício dos interesses do patrocinador, do pesquisador ou da instituição.

O trabalho dos CEPs acontece não apenas antes do início da pesquisa, quando a análise do protocolo gera um parecer consubstanciado com recomendações sobre sua realização, mas também durante e após o estudo, com o acompanhamento de sua execução. Afinal, ao aprovar um projeto de pesquisa o comitê assume, em nome da instituição à qual está vinculado, a corresponsabilidade moral e legal por ele.

Todo e qualquer CEP só é instituído por demanda da direção da instituição e no caso em que esta atenda aos requisitos mínimos para sua criação, entre os quais a realização de um número de pesquisas que o justifique. Para sua admissão no sistema CEP- 
Conep (Comissão Nacional de Ética em Pesquisa), é preciso submetê-lo a esta comissão, a quem cabe reconhecê-lo.

A análise dos protocolos de pesquisa é a função precípua do CEP, a qual é realizada de acordo com a Resolução 196/96, fundamentada na teoria principialista de Beauchamp e Childress (2002), ou seja, nos quatro princípios de respeito à autonomia, beneficência, não maleficência e justiça (ver Capítulo 2).

$O$ respeito à autonomia se expressa, na pesquisa, por meio do consentimento dos sujeitos de pesquisa, ou seja, aqueles que são os objetos do estudo, que são observados ou em quem são realizados os experimentos. O consentimento tem dois componentes fundamentais explicitados na regulamentação: ele deve ser livre e esclarecido. Isso significa que devem ser garantidas ao sujeito as melhores condições para que ele possa decidir participar ou não de uma pesquisa com toda a liberdade, por um lado; e por outro, para que lhe seja também garantido que, antes de tomar a decisão, ele tenha compreendido a pesquisa, seus objetivos, justificativas e procedimentos.

A liberdade e o entendimento não são questões triviais e óbvias, como pode parecer inicialmente. Garantir a liberdade significa evitar ao máximo todo constrangimento para o sujeito da pesquisa. Por exemplo, se a única possibilidade de receber tratamento para o seu problema de saúde vislumbrada pelo sujeito for a sua participação em uma pesquisa clínica, ele estará numa situação em que não poderá escolher não participar, visto que necessita de tratamento. Outro exemplo: imagine uma pesquisa populacional em uma comunidade com alto índice de pobreza. Conduzir um estudo sobre o recebimento de algum benefício de um programa governamental envolverá uma possi- 
bilidade razoável de que a pesquisa seja confundida com uma avaliação oficial - obrigatória, portanto. Um cuidado que pode ser tomado no caso do primeiro exemplo é verificar se todo potencial sujeito de pesquisa tem garantido o acesso à assistência, independentemente do aceite para participar do estudo. No segundo exemplo, o pesquisador terá de deixar muito claro, além dos objetivos e todos os elementos de esclarecimento previstos para qualquer pesquisa, a diferença entre a pesquisa e uma avaliação oficial e as formas de garantir confidencialidade dos dados obtidos no estudo.

Garantir que todas as medidas tenham sido previstas para que o sujeito de pesquisa seja suficientemente esclarecido é uma etapa fundamental da avaliação ética de um protocolo de pesquisa. O CEP avaliará o processo de consentimento: a maneira como, e por quem, o sujeito de pesquisa será abordado, as estratégias a serem utilizadas para que este compreenda os objetivos, justificativa e relevância do estudo. Não se admite que a falta de educação formal, ou simplesmente os baixos níveis de escolaridade, seja motivo para que os sujeitos da pesquisa não a compreendam. Quanto maior a dificuldade de entendimento dos sujeitos da pesquisa, maior deverá ser o esforço do pesquisador e sua equipe para superar ao máximo, e de forma criativa, tais limitações.

O Termo de Consentimento Livre e Esclarecido (TCLE) é o instrumento pelo qual se documenta que o sujeito de pesquisa foi esclarecido. O TCLE deve ser escrito e assinado pelo pesquisador e também pelo sujeito de pesquisa. É relativamente comum encontrarmos TCLE que apresenta muito pormenorizadamente todos os procedimentos da pesquisa sem, no entanto, esclarecer o que de fato o pesquisador espera gerar de conhecimento novo 
com o desenvolvimento do estudo. Um exemplo é o TCLE que apresenta com detalhes a coleta de material da cavidade bucal usando-se um swab, mas não informa que o objetivo é identificar a flora bucal nem que o procedimento é parte de um projeto que visa a comparar o impacto de diferentes patologias sobre a qualidade e a quantidade da flora bucal. Em resumo, não é suficiente que o pesquisador solicite ao sujeito de pesquisa sua autorização para realizar determinados procedimentos. O respeito devido às pessoas exige que o pesquisador encare o sujeito que participa da pesquisa como uma pessoa autônoma inteiramente responsável por seus atos, o que significa que ela participará do estudo se julgar que os objetivos são razoáveis e relevantes. A omissão de qualquer objetivo da pesquisa por parte do pesquisador é inaceitável.

Mas não basta o respeito à autonomia das pessoas; a pesquisa tem de apresentar um balanço de riscos e benefícios favorável aos benefícios. Qualquer pesquisa, na medida em que é formulada para preencher uma lacuna do conhecimento, uma incerteza, envolve riscos desconhecidos. Quando o CEP avalia um protocolo de pesquisa, esse balanço deve ser feito; caso os riscos superem os benefícios, mesmo que haja previsão de consentimento e que o sujeito de pesquisa seja esclarecido, não é considerado eticamente adequado que o pesquisador submeta outras pessoas a riscos. Um exemplo é o uso do placebo para um teste de medicamento quando já existir tratamento eficaz para a condição mórbida em investigação. Um novo medicamento para tratar uma enfermidade $\mathrm{X}$, testado contra placebo, colocaria o grupo que está usando o placebo em risco (sem tratamento adequado), sem qualquer benefício associado. Nessa situação, mesmo que o sujeito consinta em participar da pesquisa, pelo 
balanço de riscos e benefícios desfavorável, esta não pode ser considerada eticamente adequada.

Outro ponto fundamental para avaliação da eticidade da pesquisa são as medidas previstas no protocolo para mitigação dos riscos. Todos os riscos previsíveis têm de ser minimizados, ou, quando inevitáveis, suas consequências têm de ser tratadas. É o caso de medicamentos em teste que apresentam reações adversas. É obrigação do pesquisador e da instituição garantir atendimento a todas as intercorrências. Mesmo quando um estudo for observacional, como um inquérito populacional para avaliar determinada condição de saúde, o protocolo deverá prever o encaminhamento do sujeito de pesquisa em que porventura seja detectado qualquer problema de saúde.

O princípio de justiça aplicado à ética em pesquisa orienta a análise do protocolo no sentido da equidade na distribuição dos riscos e benefícios. O que significa dizer que a pesquisa que envolve humanos deve ter relevância social, ou seja, precisa ter sua importância reconhecida socialmente; não basta que seja algo que tenha despertado a curiosidade do pesquisador, que este deseje conhecer melhor. Além disso, aqueles que participam da pesquisa devem ter benefícios significativos. Quanto aos riscos inerentes a qualquer projeto de pesquisa, devem ser distribuídos de maneira tal que os menos vulneráveis assumam a maior parcela. Suponhamos um projeto para avaliar a eficácia de um medicamento para leishmaniose que se utilizará em um grupo de soldados. Ora, se a leishmaniose não é uma doença de soldados, não faz sentido que a população do estudo se restrinja a esse grupo, uma vez que outras pessoas terão mais liberdade do que os soldados, submetidos a rígida hierarquia, para se recusar a participar. 
As populações indígenas demandam um olhar diferenciado por parte dos pesquisadores. As diferenças culturais não podem ser minimizadas, ainda que se pretenda realizar a pesquisa em comunidades onde já se fala o português, pois, geralmente, o nosso idioma é apenas uma segunda língua para eles. Afora isso, as notórias diferenças culturais e mesmo de valores são algumas das questões que precisarão ser abordadas de forma particular.

Assim, o trabalho do CEP é analisar protocolos de pesquisas segundo uma abordagem principialista, entendendo que os princípios de respeito à autonomia, beneficência, não maleficência e justiça são obrigações prima facie. Para que um princípio deixe de ser respeitado é necessário que haja muito bons motivos. E se dois princípios entrarem em conflito, será necessário um esforço do pesquisador em formular argumentos racionais convincentes para que o comitê os avalie e os aceite, sempre tendo em conta a finalidade de proteger os sujeitos de pesquisa.

\section{COMISSÕES DE BIOÉTICA HOSPITALAR}

As distinções iniciais entre as chamadas comissões de ética hospitalar e as comissões de bioética passam pelo reconhecimento de que as primeiras - denominadas "profissionais" - serão sempre compostas por membros de uma única corporação (ainda que assessoradas por profissionais do direito, por exemplo), enquanto que as de bioética são necessariamente multiprofissionais e multidisciplinares. Como visto, as comissões "profissionais" têm como meta o cumprimento das normas corporativas, ao passo que as de bioética lidam com referenciais mais diferenciados - os da própria bioética. 
De acordo com o que discutimos no Capítulo 1, aquela que pode ser considerada a primeira comissão de bioética hospitalar foi criada no contexto da disputa por vagas para hemodiálise. O segundo registro relevante sobre comissões hospitalares na história da bioética também foi referido no início deste livro - a demanda judicial para que o hospital onde Karen Anne Quinlan esteve internada ouvisse a sua comissão de ética sobre o prognóstico de sua condição clínica. Notem que a deliberação da Suprema Corte incorreu em um erro, pois demandou que uma comissão de ética (que não existia em nenhum hospital àquele tempo) emitisse um juízo clínico - de prognóstico. Se a comissão tivesse, efetivamente, como objetivo a avaliação prognóstica do caso, ela deveria ter uma composição forte no campo da neurologia - o que não foi o caso. A comissão opinou se era correto ou não retirar Karen do respirador, visto que seu quadro clínico não correspondia aos critérios definidores de morte e havia a demanda familiar pela interrupção das chamadas medidas extraordinárias de suporte à vida.

Em 1982, ocorreu outro episódio de grande repercussão para o campo: os pais de uma criança com múltiplas lesões congênitas não autorizaram uma cirurgia. A indicação de cirurgia para esse infante, a qual ficou conhecida como Baby Doe - se John Doe pode ser traduzido para o português como João da Silva, ou Fulano de Tal, Baby Doe seria Bebê de Tal -, era considerada imprescindível para sua sobrevivência. A equipe médica demandou uma autorização judicial para realizar a cirurgia, que foi negada. Confrontaram-se duas posições antagônicas: a da equipe de saúde, que entendia que toda e qualquer condição de sobrevida era adequada e, portanto, tudo deveria ser feito para que esse 
bem-estar fosse alcançado; e a dos pais da criança, os quais entendiam que o sofrimento ao qual ela seria exposta, com baixa possibilidade de sobrevida e recuperação, não se justificaria. A partir desse caso, foram criados vários comitês de revisão para analisar situações de suspensão ou manutenção do suporte à vida de recém-nascidos com incapacidades.

Um relatório de 1983 da comissão presidencial para o estudo dos problemas éticos na medicina e na pesquisa biomédica e comportamental considerou urgente que profissionais dedicados aos cuidados de saúde e hospitais desenvolvessem mecanismos para revisão e consulta em casos que suscitassem questões éticas. De forma específica, estimulou a formação de comitês de ética hospitalares para a revisão de casos que apresentassem conflitos e dilemas éticos, tendo em vista sua tentativa de resolução. Esses autores também relataram que, em 1982, nos Estados Unidos, apenas 1\% dos hospitais possuía um comitê de ética, ao passo que, em 1987, esse índice alcançou 60\%, mostrando uma forte adesão à proposta. Entretanto, tais comitês continuam não obrigatórios de acordo com a regulamentação estadunidense, embora sua criação tenha sido apoiada desde o início pela Associação Médica Americana, Associação de Hospitais Americanos, Academia Americana de Pediatria e Academia Americana de Neurologistas.

Os comitês de bioética, entretanto, não são uma organização apenas dos Estados Unidos, embora tenham surgido naquele país. Algumas nações já incorporaram a proposta e a implementaram, enquanto outras o farão agora, pois em 2005 os países membros da Unesco aprovaram, por unanimidade, a Declaração sobre Bioética e Direitos Humanos que recomenda, em seu 
artigo 19, a criação de comitês de ética independentes, multidisciplinares e pluralistas. A rigor, a declaração refere-se a dois tipos de comitês: os de ética em pesquisa, que deverão avaliar os problemas éticos, jurídicos, científicos e sociais relevantes dos projetos de investigação que envolvem seres humanos; os hospitalares, que deverão dar pareceres sobre os problemas éticos que se apresentam em contextos clínicos. Ambos terão que se comprometer com a avaliação dos progressos científicos e tecnológicos, com a formulação de recomendações, e contribuir para a elaboração de princípios normativos sobre as questões do âmbito da referida declaração, bem como com a promoção do debate, da educação e da sensibilização e mobilização do público em matéria de bioética.

Os comitês - ou comissões - hospitalares de bioética podem ter pelo menos três funções diferentes, as quais podem ser cumulativas: educativa, formuladora de políticas e consultiva. Vejamos o que se pode resumir sobre cada uma dessas funções.

A primeira função, educativa, costuma se direcionar a três públicos em geral: à própria comissão; ao corpo médico e demais membros da equipe de saúde e demais funcionários da unidade de cuidado da saúde; à população em geral. A forma de atuação pode incluir a criação de um veículo de comunicação/informação (seja um boletim, seja uma página na Internet ou alternativa), reuniões de discussão da bibliografia em bioética com os membros do comitê, ou mesmo rounds éticos, com a equipe do comitê visitando os serviços para discutir casos selecionados previamente ou com pequenos eventos voltados para o público selecionado. No Brasil, uma comissão de bioética que tem a prática dos rounds de ética é a do Hospital Universitário Clemen- 
tino Fraga Filho, vinculado à Universidade Federal do Rio de Janeiro (UFRJ). Está claro, apesar da utilização da expressão round, que a discussão não se dá na beira do leito.

A função de formular políticas institucionais sobre questões éticas é bastante comum nos hospitais dos Estados Unidos, e significa o estabelecimento (ou a revisão) de determinações institucionais sobre a manutenção ou suspensão de tratamentos regulares ou excepcionais ou, ainda, sobre reanimação cardiorrespiratória. O comitê será acionado especificamente para essa atividade pela direção do hospital ou por outras instâncias colegiadas da unidade, ou ainda por iniciativa do próprio comitê. No Brasil, uma comissão que tem essa atividade como uma de suas responsabilidades principais é a do Conselho de Bioética do Instituto Nacional de Câncer (Conbio/Inca), que assessora a direção geral quanto à ética constante da Política Nacional de Prevenção e Controle do Câncer e analisa os conflitos morais referentes à prevenção, educação, pesquisa, tratamento e cuidados paliativos na área da oncologia, submetidos ao Conbio pela direção geral, tendo em vista recomendações normativas (Inca, 2009).

A terceira função identificada para as comissões de bioética hospitalares diz respeito às chamadas consultas éticas, ou seja, demandas por uma avaliação retrospectiva ou prospectiva em relação a um caso específico que suscite questões morais reconhecidas como de difícil solução. Podemos chamar de pareceres éticos, para facilitar a identificação do processo. Nos Estados Unidos - o Comitê de Bioética Clínica do Medical Center da Georgetown University pode ser tomado como exemplo (Georgetown University, 2009) -, as comissões de bioética podem ser 
acionadas para uma consulta tanto por membros da equipe de profissionais da saúde encarregados do caso quanto por pacientes ou seus familiares; no caso de instituições com assistência religiosa institucional - situação do Medical Center -, os capelães hospitalares também podem demandar uma consulta ética para determinado caso.

É importante refletir sobre a possibilidade de qualquer pessoa ou instância demandar um parecer ético sobre um determinado caso. Deve ficar claro que tal possibilidade não é, e não deve ser, sem restrições. Uma condição para solicitar tal parecer é que o demandante esteja envolvido no cuidado daquele paciente específico. Não é razoável imaginar que qualquer um que passe pelos corredores de um hospital possa se achar no direito de intervir na conduta adotada pela equipe encarregada do cuidado, conduta esta acordada com o paciente ou, no caso de sua impossibilidade de tomar decisões, com seus responsáveis legais e morais. Da mesma maneira, não parece razoável que essa possibilidade de interferência não seja restrita, no caso dos capelães hospitalares, às situações em que os pacientes comunguem da mesma religião e tenham aceitado e desejado seu acompanhamento.

Em relação às consultas bioéticas, ou pareceres bioéticos, três médicos que atuam há mais de duas décadas na área de bioética clínica publicaram uma análise do funcionamento dos comitês e da atuação dos consultores em ética (Singer, Pellegrino \& Siegler, 1990) em que identificaram quatro modalidades de consultas éticas: aquela em que o comitê é acionado sem consultas específicas; aquela em que um membro do comitê atua como consultor e suas consultas não são sistematicamente revistas pelo comitê; a do comitê revisor post-facto, na qual o comitê revê os pareceres 
após a conclusão dos fatos que geraram a consulta ética; a consulta pura, sem comitê, que configuraria apenas um serviço de consultas éticas.

$\mathrm{Na}$ hora da discussão dos possíveis modelos de funcionamento dos comitês de bioética hospitalar, é indispensável definir com clareza quais os seus propósitos. Está claro que o comitê não pode servir para tirar a responsabilidade do médico e da equipe de cuidado sobre as decisões a serem tomadas em cada caso. É inadmissível que o comitê (ou o consultor) pretenda usurpar a responsabilidade do profissional da saúde na tomada de decisões ou que o médico queira se eximir dessa responsabilidade delegando-a ao comitê. Como assinalaram Singer, Pellegrino e Siegler (1990), o objetivo central da consulta ética é melhorar o cuidado oferecido ao paciente. Eles destacam, acertadamente, que as recomendações e avaliações realizadas na consulta ética devem ser compreendidas como contribuições para a reflexão dos sujeitos envolvidos. Essas contribuições, ainda que se apresentem agregadas a orientações ou recomendações, devem ser ponderadas pelos sujeitos e aceitas ou não. O comitê, ou o consultor, pode atuar até mesmo como facilitador do diálogo entre profissionais, pacientes e familiares, mas não como usurpador da responsabilidade de decidir, atuando para convencer A ou B desta ou daquela decisão. Destacamos, igualmente, que não se trata de uma função que possa ser exercida por qualquer pessoa. São necessárias habilidades e competências específicas no campo das relações humanas, assim como clínicas, morais e éticas. A competência clínica aqui referida não determina que aquele que atuará como consultor ético tenha de ser médico, mas sim que ele não pode ser um completo estranho 
ao campo, ignorante em relação aos aspectos fundamentais do processo saúde-enfermidade e da clínica propriamente dita. Nos Estados Unidos, a Society for Health and Human Values e a Society for Bioethics Consultation elaboraram um documento sobre padrões para a consulta bioética. Esse documento, posteriormente adotado pela American Society for Bioethics and Humanities, determinou, entre outros, que não houvesse um processo de acreditação de comitês ou de consultores, e que era necessário dar início a um processo de avaliação tanto dos processos de consultas éticas como de seus resultados; este é um dos principais desafios que ainda precisam ser enfrentados.

A seguir apresentaremos aspectos da constituição das comissões hospitalares de bioética no Brasil. Porém, antes de apresentarmos um resumo consolidado das experiências em curso no país, vale refletir sobre a propriedade e pertinência da criação desses comitês ou serviços de bioética em unidades de saúde brasileiras. Será que eles não são apenas (mais) uma importação acrítica de modelos alienígenas? Haverá, de fato, necessidade desse tipo de comitês nos hospitais nacionais, se considerada a história política e cultural e os valores que preponderam em nossa sociedade? Não será mais um exemplo da ação imperialista estadunidense ou, quem sabe, mais um exemplo da submissão colonial que faz com que (alguns? muitos?) intelectuais brasileiros busquem copiar o que existe na metrópole, no afã de se parecer com ela?

A resposta a esses questionamentos refuta tais ideias e defende a pertinência dos modelos; apesar de não haver, no Brasil, a demanda judicial que caracterizou o processo nos Estados Unidos, o modelo de consultas e pareceres bioéticos na clínica é pertinente e poderá melhorar não apenas a qualidade do cuidado 
da saúde oferecido aos pacientes, como também o próprio processo de trabalho em saúde.

Parece claro que o Brasil não é um destaque histórico na defesa dos direitos individuais. A rigor, a despeito da garantia formal dos direitos individuais nas diversas constituições democráticas já promulgadas, esses direitos quase sempre foram intensamente regulados e controlados pelo Estado. Também, na prática clínica, prevaleceu um modelo paternalista, com a quase total submissão dos pacientes àquele que detém a autoridade técnica e cultural sobre a saúde e a doença - o médico.

Apesar de os códigos de ética profissional reiteradamente afirmarem os direitos dos pacientes em decidir o que desejam para suas próprias vidas, proibindo os médicos de realizar procedimentos contra a vontade daqueles, as exceções também são estabelecidas pelos códigos. A primeira e a mais importante é o risco de morte para o paciente. Se o médico entender que determinado procedimento é fundamental para salvar a vida do enfermo - caso contrário, a exporá a grande perigo -, o Código de Ética Médica autoriza a sua realização (ou não), independentemente da vontade ou desejo do paciente. A manutenção da vida é tida como o princípio mais importante para a prática médica, valendo qualquer coisa para garanti-la. A questão que se coloca é: o que é vida? No cotidiano - âmbito reforçado pelo Código de Ética Médica - o indivíduo é, com frequência, compreendido apenas em sua dimensão biológica, o que reduz a avaliação de seu bem-estar à sua adequação aos parâmetros laboratoriais reconhecidos como 'fisiológicos' ou, por que não dizer, de normalidade - ou seja, a vida é apenas biológica, 'nua'. Assim, lidar com o indivíduo doente muitas vezes acaba se resumindo a lutar con- 
tra as alterações no reconhecido estado de normalidade. Então, para um médico com uma compreensão de seu papel como a que caracterizava a prática médica até meados do século XX, há sempre o que tentar com qualquer paciente, pois sempre existe a possibilidade de fazer algo para que alguns parâmetros laboratoriais se aproximem da faixa reconhecida como de normalidade. Assim, qualquer tentativa de controlar as possibilidades de intervenção nos esforços pela normalização das funções biológicas é vista como um risco para a vida e o bem-estar do indivíduo. Dessa maneira, é muito difícil para um médico, com essa visão clássica de seu papel e do processo de saúde-enfermidade, aceitar ou apoiar as decisões dos pacientes que negam a ele o exercício de sua autoridade no esforço para cumprir aquela que ele entende ser a sua missão. Daí surge o argumento, corriqueiro, segundo o qual o paciente não tem domínio técnico para efetivamente compreender a situação e tomar decisões apropriadas - em geral, a decisão considerada apropriada é concordar com o médico. Desqualifica-se a discordância de opiniões e visões de mundo para justificar a tomada de decisões em nome dos pacientes, ainda que contrariando o que eles desejariam ou manifestam desejar.

Outro argumento que com freqüência é apresentado nas discussões sobre o respeito à autonomia dos pacientes é o de que eles dificilmente estão em condições emocionais de discutir questões tão sérias ou graves sobre as condutas que devem ser adotadas. Mais uma vez, trata-se de um argumento que não se sustenta, pois se baseia em uma premissa não testada e desconsidera, na prática, o pressuposto de que cada indivíduo deve ser reconhecido como um sujeito e agente moral. Todo sujeito deve 
ser considerado como um agente moral que busca sua autodeterminação. Grande esforço deve ser feito para garantir a todos o atendimento ao seu projeto individual de felicidade, que pode não ser igual ao dos demais profissionais da saúde; além disso, muitas vezes nem mesmo os familiares compreendem e aceitam o projeto de vida de alguém. Perguntamos, então: é correto que alguém que discorde do projeto de vida e de felicidade de alguém tome, em seu nome, decisões que o contrariem? Não parece razoável, ainda que na avaliação daquele que toma tais decisões estas se baseiem, de forma bem intencionada, no maior interesse do paciente.

Essas discussões estão inseridas no âmbito das reflexões sobre a competência dos pacientes para tomar decisões. É ou não é o paciente competente para decidir nos momentos em que está enfermo e nos quais decisões cujas consequências são de grande impacto em sua vida e na de sua família precisam ser tomadas? Haverá equilíbrio emocional e discernimento suficientes para que tome as decisões apropriadas? Gostaríamos de contar uma breve história, claramente simplificada, apresentada por Aulisio, Arnold e Youngner (2003), para ilustrar melhor o problema. Eles propõem que você se imagine de plantão em um pronto-socorro quando dá entrada uma mulher vítima de um grave acidente de motocicleta. Ela apresenta uma séria lesão vascular na perna direita. As alternativas terapêuticas são: retirada de uma veia do pulso da paciente e utilizá-la para salvar sua perna, o que causará uma leve disfunção no pulso, ou amputar a perna. A paciente opta pela amputação da perna. Essa decisão, contrária ao que podemos considerar como o senso comum, expõe as dificuldades que temos de aceitar que outras pessoas tenham valores diferen- 
tes dos nossos. Nosso primeiro impulso é considerar que essa paciente não estaria em condições de tomar suas decisões. Mas, conversando com ela vamos descobrir que é uma concertista de piano. Segundo os nossos valores, a leve disfunção seria a opção apropriada, mas segundo os valores da paciente a amputação é o melhor tratamento oferecido.

Entendendo, na própria tradição hipocrática, que o fim último da medicina e do cuidado da saúde é o bem do paciente, é preciso ter claro que esse bem não é redutível a uma definição clínica, e a ele incorporando as subjetividades e os próprios valores da pessoa. Não há, nessa afirmação, qualquer novidade; pois não é novidade preconizar um tratamento holístico para o enfermo, que reconheça as peculiaridades e especificidades da vida, do adoecimento e da morte de cada indivíduo. Como disse J. Ortega y Gasset, "Yo soy yo y mi circunstancia y si no la salvo a ella no me salvo yo".

Existem poucos relatos disponíveis que permitam contar essa breve história das comissões hospitalares no país. Poucos comitês oferecem aos interessados informações consolidadas sobre suas experiências. Um dos poucos que já disponibilizaram essa história é aquele que é reconhecido como o primeiro comitê hospitalar de bioética - o grupo de trabalho vinculado ao Programa de Apoio aos Problemas de Bioética no Hospital de Clínicas de Porto Alegre, vinculado à Universidade Federal do Rio Grande do Sul (UFRGS). O programa foi criado em novembro de 1993 com o objetivo de "desenvolver atividades de apoio aos profissionais da instituição, pacientes e familiares que tenham dilemas morais resultantes de ações assistenciais" (Goldim et al., 1998: 212). Os dados que obtivemos sobre esse programa mos- 
tram que a demanda por consultas aos membros do grupo de trabalho praticamente dobravam a cada ano de funcionamento, e que os demandantes de consultas eram, em mais da metade dos casos, professores de medicina vinculados à universidade. O programa funciona como um comitê e como um serviço de consultas. Os participantes reúnem-se uma vez por mês para discussão de casos e reflexão sobre normas (funcionamento típico de um comitê) e para consultas com respostas em até 24 horas, no que contam com a participação de dois consultores que ficam alcançáveis diariamente. Atualmente, são realizadas visitas de rotina aos serviços pediátricos com o propósito de fomentar consultas e discussões nessas áreas.

O segundo comitê a ser criado foi o do Hospital São Lucas, vinculado à Pontifícia Universidade Católica do Rio Grande do Sul, em Porto Alegre, em 1995. Esse comitê conta hoje com 17 membros de diversas formações profissionais (um terço deles é de médicos) e representantes da administração do hospital, da Igreja católica e de outras comissões hospitalares. Em dez anos de funcionamento do comitê, há referência a 82 consultas. Um substancioso relato dessas experiências gaúchas feito por Goldim e colaboradores (2008) demonstra a consistência do trabalho desenvolvido por eles, que pode contribuir para sua disseminação pelo Brasil.

Com base nessas experiências, outras foram desenvolvidas, como a do Hospital Universitário da Universidade Estadual de Londrina, a do Hospital das Clínicas da Universidade de São Paulo (USP), a do Instituto Nacional de Câncer e a do Hospital Universitário da UFRJ. Notamos que, além do programa da UFRS, também a USP tem demonstrado grande preocupação em não 
apenas desenvolver um trabalho que merece toda a nossa atenção e admiração, mas também em divulgar adequadamente sua experiência. Nos tempos atuais de massiva conectividade, parecenos incompreensível que alguns desses hospitais (e de outros tantos que já contam com suas próprias comissões) não tenham sequer uma página de divulgação e comunicação na Internet. Nesse sentido, a comissão do Hospital de Clínicas da USP é primorosa, pois não só divulga os nomes dos seus participantes como também os pareceres na íntegra, o regimento interno e outras informações relevantes para os membros de sua comunidade e para a sociedade em geral.

Merece igualmente destaque e comentário o fato de não se tratar de um acaso ou uma coincidência que todos esses hospitais tenham vínculo com organizações acadêmicas e de pesquisa. Por estarem na vanguarda do conhecimento científico, têm mais facilidade para compreender as vantagens de tais propostas, inclusive do ponto de vista educacional. Variando em termos de estrutura e funcionamento, conseguem demonstrar, com tal diversidade, que não deve existir um modelo fechado de comitê, mas todos devem ser estruturados de acordo com o que se espera deles, com os objetivos de sua criação e funcionamento. E, especialmente, deve-se oferecer uma formação apropriada para todos os que desejarem atuar como consultores ou membros do comitê. Precisamos acabar com a ideia de que um pouco de bom senso basta, pois isto é uma falácia. 



\section{EPÍLOGO}

Neste livro propusemos apresentar, ao leitor não especialista, um panorama da bioética em duas perspectivas: a da disciplina acadêmica e a do saber aplicado a diversos problemas relacionados com o cotidiano das práticas em saúde. Mais do que isso, procuramos apresentar a bioética como saber capaz de, recuperando a imagem de Potter - o qual propôs a bioética como uma ponte entre dois saberes -, construir uma nova ponte entre a prática clínica e a prática em saúde pública. Esse entendimento representa mais do que uma proposta teórica abstrata, mas uma prática necessária e, a rigor, imperativa.

Esta é uma primeira iniciativa de apresentação da bioética como ponte. Estamos preparando uma continuação do presente livro, na qual discutiremos, de forma mais amiúde, os aspectos éticos do desenvolvimento científico e da inovação no setor Saúde do país. O novo volume terá como foco, de forma mais aprofundada, o problema da ética em pesquisa incluindo o campo das pesquisas que envolvem seres vivos não humanos -, as fronteiras do conhecimento - incluindo a reprodução assistida, a clonagem e as questões que afloram na genômica, tais como as discussões sobre terapia gênica, eugenia e clonagens de humanos e não humanos - e os aspectos das relações homem-ambiente no domínio das interseções entre bioética e ecologia. 
O grande incremento nos recursos tecnológicos disponíveis para o cuidado da saúde é, com frequência, identificado como sinal de avanço científico. De fato, devemos reconhecer que o intenso processo de separação do trabalho na saúde, com a divisão e multiplicação do conhecimento e o consequente surgimento de novas profissões, é também um dos sinais dos avanços observados no cuidado da saúde. A boa técnica desse cuidado não admite que se veja um paciente como um indivíduo isolado de sua família, de seu trabalho, de seu lazer, de suas experiências físicas e emocionais antecedentes; ao contrário, é preciso entender o sujeito em sua integralidade, oferecendo-lhe um cuidado também integral. Mas, como pudemos observar nas páginas antecedentes, não é factível desconsiderar os problemas morais relacionados com esse cuidado. As expectativas que a sociedade tem, no tocante ao cuidado da saúde, incluem no mínimo, e sem sombra de dúvida, o respeito aos seus direitos individuais e coletivos. Mais do que isso, esperamos a consideração ao indivíduo e à sua comunidade, entendendo que as diferenças sociais existentes em um país como o Brasil devam tornar a preocupação com a justiça e com a proteção dos concidadãos um verdadeiro imperativo ético, de modo a que o cotidiano na prática em saúde seja um permanente decidir sobre questões morais. A cada prescrição, internação, alta, indicação de vacina ou de procedimento, um gigantesco universo de perguntas e questionamentos se apresenta na mente dos protagonistas - sem que estes, muitas vezes, tenham sido, em algum momento, preparados para tomar tais decisões.

Apesar dos limites que um livro com estas dimensões impõe, acreditamos que ele poderá auxiliar na abordagem dos desafios 
de agora e do futuro, estimulando a reflexão e a busca por novas leituras, tendo em vista, sempre, aquele que, quiçá, pode ser considerado o objetivo maior da bioética: reconhecer o outro como interlocutor legítimo nos diálogos e ações atinentes ao cuidado da saúde. 



\section{REFERÊNCIAS}

ABBAGNANO, N. Dicionário de Filosofia. 4. ed. São Paulo: Martins Fontes, 2003.

\section{AMERICAN COLLEGE OF EMERGENCY PHYSICIANS} (ACEP). Code of Ethics for Emergency Physicians. Versão jun. 2008. Disponível em: <www.acep.org/practres.aspx?id=29144>. Acesso em: 14 fev. 2009.

AULISIO, M. P.; ARNOLD, R. M. \& YOUNGNER, S. J. (Eds.). Ethics Consultation: from theory to practice. Baltimore: The Johns Hopkins University Press, 2003.

BEAUCHAMP, T. \& CHILDRESS, J. F. Princípios de Ética Biomédica. 4. ed. São Paulo: Edições Loyola, 2002.

BRASIL. CONSELHO NACIONAL de Saúde. Resolução 01 de 14 de junho de 1988. Disponível em <www.conselho.saude.gov.br/ resolucoes/reso_88.htm>. Acesso em: 10 mar. 2009.

BRASIL. CONSELHO NACIONAL de Saúde. Resolução 196 de 10 out. 1996. Disponível em: <www.conselho.saude.gov.br/ resolucoes/1996/Reso196.doc>. Acesso em: 10 mar. 2009.

BRASIL. CONSELHO FEDERAL de Medicina. Resolução n. 1.805/2006. D.O.U., 28 nov. 2006, seção I, p. 169. Disponível em: <www.portalmedico.org.br/resolucoes/cfm/2007/111_2007. htm>. Acesso em: 28 set. 2009.

CHILDRESS, J. F. A principle based approach. In: KUHSE, H. \& SINGER, P. (Org.). A Companion to Bioethics. Oxford: Blackwell Publishers, 1998. 
DINIZ, D. Quando a morte é um ato de cuidado: obstinação terapêutica em crianças. Cadernos de Saúde Pública, 22(8): 1.741 $1.748,2006$.

DINIZ, D. \& ALMEIDA, M. Bioética e aborto. In: GARRAFA, V.; OSELKA, G. \& IBIAPINA, S. (Orgs.). Fundamentos da Bioética. Brasília: CFM, 1998.

DINIZ, D. et al. Aborto: 20 anos de pesquisas no Brasil Cadernos de Saúde Pública, 25(4): 939-942, 2009.

FERRAZ-NETO, B.-H. Transplante de fígado: angústia da espera ao sucesso pós-operatório. Jornal Brasileiro de Transplantes, 9(2): 515, 2006. Disponível em: <www.abto.org.br/abtov02/portugues/ $\mathrm{jbt} /$ vol9n_2/volumeCompleto.pdf\#page=14>. Acesso em: 02 fev. 2009.

FERRAZ-NETO, B.-H \& AFONSO, R. C. Evolução e perspectivas do transplante de fígado no Brasil. Prática Hospitalar, 50: 167-170, 2007.

FERRER, J. J. \& ÁLVAREZ, J. C. Para Fundamentar a Bioética. São Paulo: Loyola, 2005.

FOUCAULT, M. Microfísica do Poder. 23. ed. São Paulo: Graal, 2008.

FUSCO, C. L. B.; ANDREONI, S. \& SILVA, R. S. Epidemiologia do aborto inseguro em uma população em situação de pobreza, Favela Inajar de Souza, São Paulo. Revista Brasileira de Epidemiologia, 11(1): 78-88, 2008.

GEORGETOWN UNIVERSITY. Bioethical Clinical Committee of Medical Center, Georgetown University, 2009. Disponível em: $<$ clinicalbioethics.georgetown.edu/consult $>$. Acesso em: 19 jan. 2009.

GOLDIM, J. R. et al. A experiência dos comitês de ética no Hospital de Clínicas de Porto Alegre. Bioética, 6(2): 211-216, 1998. Disponível em: <www.portalmedico.org.br/revista/bio2v6/ expcometicapa.htm $>$. 
GOLDIM, J. R. et al. Clinical bioethics committees: a Brazilian experience. Journal International de Bioetbique, 19(1-2): 181-192, 2008.

HARE, R. M. A utilitarian approach. In: KUHSE, H. \& SINGER, P. (Orgs.). A Companion to Bioethics. Oxford: Blackwell Publishers, 1998.

HARRIS, J. The survival lottery. Pbilosophy, 50(191): 81-87, 1975.

HEIDEGGER, M. Ensaios e Conferências. Petrópolis: Vozes, 2001.

HORTAL, A. Ética. Madri: Univ. Pontifícia Comillas, 1994.

INSTITUTO NACIONAL DE CÂNCER (INCA). ConBio:

Conselho de Bioética. Disponível em: <www.inca.gov.br/ conteudo_view.asp?id=674>. Acesso em: 19 jan. 2009.

KANT, I. Fundamentação da Metafísica dos Costumes. Lisboa: Edições 70, 1988.

KONNER, M. Becoming a Doctor: a journey of initiation in medical school. New York: Penguin Books, 1987.

KUHSE, H. \& SINGER, P. (Orgs.). A Companion to Bioethics. Oxford: Blackwell Publishers, 1998.

LEVIN, B. W. \& FLEISCHMAN, A. R. Public health and bioethics: the benefits of collaboration. American Journal of Public Health, 92(2): 165-167, 2002.

MANNING, R. A care approach. In: KUHSE, H. \& SINGER, P. (Orgs.). A Companion to Bioethics. Oxford: Blackwell Publishers, 1998.

MURARO, R. M. El aborto y la fe religiosa en América Latina. In: PORTUGAL, A. M. (Orgs.). Mujeres e Iglesia: sexualidad y aborto en América Latina. Washington, México: Catholics for a Free Choice, Distribuciones Fontamara, 1989.

ØVERLAND, G. Survival lotteries reconsidered. Bioethics, 21(7): 355363, 2007. 
RACHELS, J. Ethical theory and bioethics. In: KUHSE, H. \& SINGER, P. (Orgs.). A Companion to Bioethics. Oxford: Blackwell Publishers, 1998.

REGO, S. Contribuições da bioética para a saúde pública. Cadernos de Saúde Pública, 23(11): 2.530-2.531, 2007.

SCHRAMM, F. R. Vida: sacralidade e/ou qualidade? Cadernos Atualidade em Debate, 34(1): 44-69, 1995.

SCHRAMM, F. S. Acerca de los métodos de la bioética para el análisis y la solución de los dilemas morales. In: BERGEL, S. D. \& MINYERSKY, N. (Coords.). Bioética y Derecho. Buenos Aires, Santa Fe, Rubinzal: Culzoni Editores, 2003.

SCHRAMM, F. R. A moralidade da biotecnociência: a bioética da proteção pode dar conta do impacto real e potencial das biotecnologias sobre a vida e/ou a qualidade de vida das pessoas humanas? In: SCHRAMM, F. R. et al. Bioética, Riscos e Proteção. Rio de Janeiro: Editora UFRJ, Editora Fiocruz, 2005a.

SCHRAMM, F. R. Bioética da proteção: justificativa e finalidades. Iatrós - Cadernos de Filosofia, Saúde e Cultura, 1: 121-130, 2005b.

SCHRAMM, F. R. \& KOTTOW, M. Principios bioéticos en salud pública: limitaciones y propuestas. Cadernos de Saúde Pública, 17: 949-956, 2001.

SINGER, P. Vida Ética. Rio de Janeiro: Ediouro, 2002.

SINGER, P. A.; PELLEGRINO, E. D. \& SIEGLER, M. Ethics committees and consultants. Journal of Clinical Ethics, I: 263-267, 1990.

SIQUEIRA-BATISTA, R. \& SCHRAMM, F. R. Conversações sobre a 'boa morte': o debate bioético acerca da eutanásia. Cadernos de Saúde Pública, 211: 111-119, 2005.

SIQUEIRA-BATISTA, R. \& SCHRAMM, F. R. A eutanásia e os paradoxos da autonomia. Ciência \& Saúde Coletiva, 13: 207-221, 2008. 
SIQUEIRA-BATISTA, R. \& SCHRAMM, F. R. A bioética da proteção e a compaixão laica: o debate moral sobre a eutanásia. Ciência \& Saúde Coletiva, 14, 1.241-1.250, 2009.

SIQUEIRA-BATISTA, R. et al. Nutrição e saúde: perspectivas revisitadas. Jornal Brasileiro de Medicina, 95: 34-45, 2008.

SUPREME COURT OF NEW JERSEY. In the matter of Karen Quinlan, an alleged incompetent, 1976. Disponível em: <philosophy.wisc.edu/streiffer/CourseFolders/ BioandLawF99Folder/Readings/In_re_Quinlan.pdf $>$. Acesso em: 26 dez. 2008.

THE ALAN GUTTMACHER INSTITUTE. Aborto Clandestino: uma realidade latino-americana. New York: The Alan Guttmacher Institute, 1994.

UNESCO. Declaração sobre Bioética e Direitos Humanos, 2005. Disponível em: < unesdoc.unesco.org/ images/0014/001461/146180por.pdf>. Acesso em: 31 jan. 2009.

VATICANO. CONGREGAÇÃO PARA A DOUTRINA da Fé. Declaração Quaestio de Abortu, 1974. Disponível em: <www. veritatis.com.br/article/4701>. Acesso em: 25 fev. 2009.

VATICANO. SAGRADA CONGREGAÇÃO para a Doutrina da Fé. Declaração sobre a Eutanásia, 1980. Disponível em: <www. vatican.va/roman_curia/congregations/cfaith/documents/ rc_con_cfaith_doc_19800505_euthanasia_po.html >. Acesso em: $10 \mathrm{dez} .2008$.

WHITEHEAD, M. The Concepts and Principles of Equity and Health. Copenhagen: World Health Organization, 1990. 



\section{Sugestões de Leituras e Filmes}

\section{LivROS}

Algumas leituras são fundamentais para os interessados em ampliar a base de seu conhecimento em bioética. Esta não é uma lista exaustiva, e os títulos, em geral, são publicações de fácil acesso no Brasil, inclusive nas livrarias com sítios na Internet.

O estudo da lógica é bastante útil para a elaboração dos próprios argumentos e para a compreensão daqueles de outrem. Quando as razões apresentadas pelo argumento não apoiam as conclusões a que se chegou, então este é falacioso. Stephen Downes, professor da Universidade de Alberta, no Canadá, disponibilizou um guia para a compreensão das falácias lógicas. Trata-se do Stephen's Guide to the Logical Fallacies, 2002. Está disponível em <www.onegoodmove.org/fallacy/welcome.htm>.

Para maiores e sistematizadas informações e reflexões baseadas na proposta teórica da bioética da proteção, é possível consultar a obra: KOTTOW, M. Ética de Protección. Bogotá: Unibiblos, 2006. Outra forma é buscar em <www.scielo.br>, por exemplo, artigos de F. Roland Schramm, que tem extensa produção acadêmica sobre o tema.

Para maiores informações sobre um enfoque liberal da bioética, podemos recorrer a ENGELHARDT JR., H. T. Fundamentos da Bioética. São Paulo: Loyola, 2004. O mesmo autor se propõe 
a apresentar uma bioética cristã em Fundamentos da Bioética Cristã Ortodoxa. São Paulo: Loyola, 2003.

Para conhecer a proposta casuística, consultar, por exemplo: JONSEN, A. \& TOULMIN, S. The Abuse of Casuistry: a bistory of moral reasoning. Berkeley: University of California Press, 1988.

Para conhecer a proposta da bioética da intervenção, de Volnei Garrafa, além da vasta bibliografia disponível em forma de artigos, é importante a leitura de alguns dos textos apresentados em GARRAFA, V. \& PESSINI, L. (Orgs.). Bioética: poder e injustiça. São Paulo Loyola, 2003.

A ética das virtudes, tão defendida e, ao mesmo tempo, tão pouco estudada na área da saúde no Brasil, pode começar a ser conhecida com a leitura de PELLEGRINO, E. \& THOMASMA, D. For the Patient's Good: the restoration of beneficence in health care. New York: Oxford, 1988.

Tendo Garrafa como um dos organizadores, foi publicada uma coletânea em que se pretendia começar a sedimentar uma perspectiva latino-americana para a bioética: GARRAFA, V.; KOTTOW, M. \& SAADA, A. (Orgs.). Bases Conceituais da Bioética: enfoque latino-americano. São Paulo: Gaia, Unesco, 2006.

A proposta preliminar de uma 'ética para todos os seres' pode ser conhecida em SIQUEIRA-BATISTA, R. Quantum bioethics: ethics for all beings. Ciência \& Saúde Coletiva, 13: 611-613, 2008. A idéia de compaixão laica, um dos fundamentos dessa concepção, pode ser encontrada em SIQUEIRA-BATISTA, R. \& SCHRAMM, F. R. A bioética da proteção e a compaixão laica: o debate moral sobre a eutanásia. Ciência \& Saúde Coletiva, 14: 1.2411.250, 2009. 
Olinto Pegoraro nos oferece uma perspectiva sempre estimulante em seus livros. Sugerimos, para conhecer o seu pensamento, iniciar a leitura por PEGORARO, O. Bioética em Temas. Rio de Janeiro: Eduerj, Faperj, 2008, e PEGORARO, O. Ética É Justiça. 7. ed. Petrópolis: Vozes, 2002.

Um clássico sobre o aborto é o trabalho de Maurizio Mori, A Moralidade do Aborto: sacralidade da vida e o novo papel da mulher. Brasilia: Editora UnB, 1997.

Da produção brasileira, recomendamos títulos que expressam, em grande parte, o olhar da bioética dirigido ao campo da saúde pública:

ANJOS, M. F.; SIQUEIRA, J. E. Bioética no Brasil, Tendências e Perspectivas. Aparecida: Idéias \& Letras, 2007.

FORTES, P. A. C. \& ZOBOLI, E. L. C. P. Bioética e Saúde Pública. São Paulo: Centro Universitário São Camilo, Loyola, 2003.

PALÁCIOS, M.; MARTINS, A. \& PEGORARO, O. (Orgs.). Ética, Ciência e Saúde. Petrópolis: Vozes, 2002.

SCHRAMM, F. R.; BRAZ, M. Bioética e Saúde: novos tempospara mulheres e crianças? Rio de Janeiro: Editora Fiocruz, 2005.

SCHRAMM, F. R.; REGO, S.; BRAZ, M. \& PALÁCIOS, M. (Orgs.). Bioética, Riscos e Proteção. Rio de Janeiro: Editora UFRJ, Editora Fiocruz, 2005.

No cada vez mais robusto campo do pensamento hoje chamado de biodireito, sugerimos a leitura de BARBOZA, H, H. \& BARRETO, V. P. Temas de Bioética e Biodireito. Rio de Janeiro: Renovar, 2001.

Como pano de fundo de toda e qualquer discussão que se faça sobre como tornar a prática em saúde mais humana, ou como 
formar profissionais mais éticos e mais humanos, abordamos o tema do ensino da ética e o papel das escolas de graduação. Para explorar esse campo, recomendamos REGO, S. A Formação Ética dos Médicos: saindo da adolescência com a vida (dos outros) nas mãos. 2. ed. Rio de Janeiro: Editora Fiocruz, 2003.

\section{FILMES}

A Experiência (Alemanha, 2001). Título original: Das Experiment. Direção: Oliver Hirschbiegel.

Esta é uma refilmagem de Stanford Prison Experiment, de 1971. Uma prisão provisória é montada em um laboratório de pesquisa. Por duas semanas, vinte homens são contratados para serem prisioneiros ou guardas nas celas, cheias de grades e câmeras de segurança. O objetivo de tudo isso é científico: os pesquisadores querem saber como esses homens reagem a penas leves, sem uso algum de violência. Inspirado em uma pesquisa real realizada na Stanford University.

As Invasões Bárbaras (Canadá, 2003). Título original: Les Invasions Barbares. Direşão: Denys Arcand.

O filme questiona em doses variadas o antiamericanismo, o holocausto indígena, a eutanásia, a globalização, a descriminação das drogas e principalmente a permanência dos valores, os quais estão acima de qualquer ideologia. Principalmente a amizade entre pais e filhos, que o dinheiro não compra.

Cobaias (EUA, 1997). Título original: Miss Evers Boys. Direção: Joseph Sargent.

Esta película, baseada em fatos reais, apresenta a história do Estudo de Tuskegee, nos Estados Unidos, no qual homens negros 
com sífilis foram impedidos de receber tratamento, para se conhecer a história natural da enfermidade.

Estado de Emergência (EUA, 1994). Título original: State of Emergency. Direção: Lesli Linka Glatter.

Neste filme, o dr. Novelli é um médico imerso em um sistema de saúde em crise, enfrentando uma quantidade sem fim de emergências e falta de equipamentos e de força de trabalho. Quando a vida de um homem vai para a balança, a questão se coloca: deve o médico jogar de acordo com as regras e deixar o homem morrer ou se arriscar e tentar salvá-lo? Essa decisão pode custar uma vida ou uma carreira.

Mar Adentro (Espanha, 2004). Título original: Mar Adentro. Direção: Alejandro Amenábar.

É a história real do militante espanhol Ramón Sampedro, que lutou por seu direito de morrer, após viver 27 anos como tetraplégico, preso a uma cama. Agora, o único contato que ele tem com o mundo é feito através da janela do seu quarto.

Menina de Ouro (EUA, 2004). Título original: Million Dollar Baby. Direção: Clint Eastwood.

O treinador de boxe Frankie está distante da filha há muito tempo porque ele mesmo é extremamente fechado em seus relacionamentos. Enquanto luta para mudar isso, chega à sua academia a jovem Maggie Fitzgerald, que está determinada a ser treinada até se tornar uma boxeadora profissional. Durante os treinos, os dois encontram mais do que amizade, um sentimento familiar perdido há anos. Mas um acidente condenará Maggie ao leito e testará sua coragem. 
O Aborto dos Outros (Brasil, 2008). Título original: O Aborto dos Outros. Direção: Carla Gallo.

A narrativa percorre situações de aborto dentro de hospitais públicos que atendem mulheres vítimas de estupro, interrupções de gestações em casos de má-formação fetal sem possibilidade de sobrevida após o nascimento e abortos clandestinos. Ao mostrar os efeitos perversos da criminalização para as mulheres, o longa indica a necessidade de que a legislação brasileira seja revista.

O Desafio da Lei (EUA, 1999). Título original: Swing Vote. Direção: David Anspaugh.

Julgamento na Suprema Corte dos Estados Unidos que autorizou, sob certas condições, a prática do aborto naquele país.

O Jardineiro Fiel (EUA, 2005). Título original: The Constant Gardener. Direção: Fernando Meirelles.

Em uma área remota no Quênia, África, uma ativista é encontrada brutalmente assassinada. O principal suspeito pelo crime é seu colega de trabalho, um médico que se encontra foragido. Perturbado pela culpa e assombrado pela possibilidade de infidelidade da esposa, Justin Quayle (Ralph Fiennes) surpreende a todos ao embarcar em uma odisseia que o leva a três continentes para descobrir o que há por trás da morte da esposa, tendo contato com o corrupto cenário das pesquisas farmacêuticas em países em desenvolvimento.

O Ovo da Serpente (Alemanha/EUA, 1977). Título original: Das Schlangenei. Direção: Ingmar Bergman.

Em novembro de 1923, em Berlim, pouco antes da tomada do poder pelos nazistas, um trapezista americano e sua cunhada viúva sobrevivem com dificuldade à violenta recessão econômica. 
Sem compreender as transformações político-sociais em curso, acabam aceitando empregos em uma clínica clandestina que faz experiências com seres humanos.

O Segredo de Vera Drake (Inglaterra, 2004). Título original: Vera Drake. Direção: Mike Leigh.

Uma mulher tem sua vida familiar destruída quando a polícia descobre que tem ajudado mulheres a abortar.

Regras da Vida (EUA, 1999). Título original: The Cider House Tules. Direção: Lasse Hallström.

Em um orfanato onde também se realizam abortos cresceu Homer, que nunca foi adotado. Treinado como médico pelo diretor do estabelecimento, Homer busca seu próprio destino saindo do orfanato para trabalhar em uma fazenda de maçãs, onde aprenderá lições sobre a vida.

Vida Severina (Brasil, 2005). Direção: Débora Diniz e Eliane Brum.

Severina é uma mulher que teve a vida alterada pelos ministros do Supremo Tribunal Federal. Ela estava internada em um hospital do Recife com um feto sem cérebro dentro da barriga, em 20 de outubro de 2004. No dia seguinte, começaria o processo de interrupção da gestação. Nessa mesma data, os ministros derrubaram a liminar que permitia que mulheres como Severina antecipassem o parto quando o bebê fosse incompatível com a vida fora do útero. 
Formato: $12,5 \times 18 \mathrm{~cm}$

Tipologia: Letter Gothic e Garamond

Papel: Off Set $75 \mathrm{~g} / \mathrm{m} 2$ (miolo)

Cartão Supremo $250 \mathrm{~g} / \mathrm{m} 2$ (capa)

CTP, impressão e acabamento: Imprinta Express Ltda.

Rio de Janeiro, outubro de 2009

Não encontrando nossos títulos em livrarias, contactar a Editora Fiocruz:

Av. Brasil, 4036 - térreo - sala 112 - Manguinhos

21040-361 - Rio de Janeiro - RJ

Tel.: (21) 3882-9039 e 3882-9041

Telefax: (21) 3882-9006

http://www.fiocruz.br/editora

e-mail: editora@fiocruz.br 